\title{
POPIS OBRTNIKA NA PODRUČJU DANAŠNJE KOPRIVNIČKO-KRIŽEVAČKE ŽUPANIJE 1890. GODINE
}

\begin{abstract}
Koprivnički, Križevački i Đurđevački kotar, formirani 1886. godine, danas su glavni dijelovi današnjeg područja Koprivničko-križevačke županije. Kao Križevačka i Đurđevačka pukovnija taj je kraj ušao u proces razvojačenja Vojne krajine spajajući se s Banskom Hrvatskom, i to u vremenu kada je željeznička pruga Nagykanizsa - Koprivnica - Zagreb - Rijeka 1873. postala glavna prometna poveznica Mađarske i Rijeke kao njezine jedine morske luke i vrata u svijet. Zahvaljujući prometnoj povezanosti, to je bilo perspektivno razvojno područje u koje su nagrnuli strani obrtnici i trgovci. Razvoj ne zahvaća samo poljoprivredu već i obrt i trgovinu te utječe na mijenjanje struktura zaposlenih i imigracije brojnih stranaca u to područje. Nažalost, između 1857. i 1890., dakle u vrijeme restrukturiranja Monarhije, na tom području izostaju statistički popisi, pa su imena obrtnika i trgovaca objavljena u Adresaru obrtnog i poslovnog svieta u Hrvatskoj 1891. godine po nalogu bana Khuen-Héderváryja uoči obilježavanja 40. godišnjice osnutka Zagrebačke trgovinske komore 1891. - riječ je o važnoj monografiji, potpuno zanemarenoj u našoj povijesnoj literaturi. Adresar ukazuje na činjenicu da ni urbanizacija ni industrijalizacija nisu još 1890 . uzele maha, ali da je obrtnika bilo mnogo, i to više na selu nego u kotarskim središtima. No čitavo područje bilo je spremno za ulazak u proces modernizacije i industrijalizacije na osnovi iskorištavanja vlastitih sirovina i velikog broja kvalificiranih radnika koje je pripremilo obrtništvo.
\end{abstract}

Ključne riječi: obrtništvo; Koprivnički kotar; Križevački kotar; Đurđevački kotar; 1890. godina.

\section{Uvod}

Područje današnje Koprivničko-križevačke županije obuhvaća tri kotara nakon 1886. godine, tj. Koprivnički, Križevački i Đurđevački, pa očito i danas postoje razlozi koji ih povezuju. Godine 1886. to je bilo područje Vojne krajine koje se 1872. počelo razvojačivati i vezati s Banskom Hrvatskom, a gradovi Koprivnica i Križevci bili su već 1870 . povezani s Mađarskom na sjeveru i Zagrebom na jugu, od 1873. i s Jadranom i Rijekom. Razvojačenje tog područja trebalo je biti uzor 
drugim područjima koja ulaze $\mathrm{u}$ taj proces deset godina kasnije, tj. 1882. godine. Mađari su bili jako zainteresirani da taj proces prođe mirno i uredno, pa su prvih godina dopuštali i na onim područjima slobode i postupke koje su kasnije zabranjivali. Takvo tretiranje Hrvatske poslije sklapanja Hrvatsko-ugarske nagodbe ponukalo je brojne nezadovoljne obrtnike i trgovce iz drugih dijelova AustroUgarske Monarhije da na tom području potraže svoj novi dom koristeći se svojim znanjima koja su stekli u gospodarski razvijenijim dijelovima Monarhije.

Do 1872. na području sjeverne Hrvatske proizvodnju i prodaju drže još uvijek cehovi u gradovima i trgovištima. Novo građansko društvo u formiranju počelo je cehove smatrati kočnicom novoga gospodarskog razvoja koji se zasnivao na znanju, konkurenciji i kapitalu. Već za banovanja Josipa Jelačića počeo je proces njihova zabranjivanja i otvaranja proizvodnih i trgovačkih poslova za obrtnike i trgovce koji su za obavljanje tih poslova stekli određene uvjete.

No reformiranje gospodarstva istovremeno s provođenjem razvojačenja Vojne krajine i njezina spajanja s Banskom Hrvatskom nije bilo jednostavan posao i otpor pogođenih društvenih slojeva bio je još dugo prisutan, pa se razvojačenju prišlo uključivanjem krajišnika - uglavnom Srba - u upravu, a kod cehova se čekalo da nove obrtničke radionice i trgovine postupno zamijene stare, nemoderne cehovske radionice. Austrijski Zakon o obrtima iz 1871. nije bio dobro primljen u području koje je Austro-ugarskom nagodbom potpalo pod ugarski dio Monarhije, pa su Mađari izradili i 1884. izdali novi Zakon o radnjama za obrt i trgovinu na osnovi potreba svojih obrtnika, trgovaca i tvorničara. Taj je zakon bio prihvaćen i u Hrvatskom saboru kao zakon, ali nije uvažavao posebnosti Hrvatske, što je izazvalo mnogo neprilika u radu obrtnika i trgovaca. Zemaljska vlada u Zagrebu imala je autonomiju samo u poslovima uprave, obrazovanja, bogoslovlja i sudstva, ali ne i u gospodarstvu i financijama. Ban Ivan Mažuranić izradio je zakone i uredbe za poslove koji su pripadali Zemaljskoj vladi, ali su mnogi od tih akata za vrijeme bana Khuen-Héderváryja izmijenjeni. Promijenjen je Zakon o školstvu i Zakon o ustrojstvu uprave. Tako su i podžupanije koprivnička i križevačka te razvojačene pukovnije križevačka i đurđevačka ušle u sastav Križevačke županije, da bi onda 1886. bile spojene s Bjelovarskom županijom, te se od tada vode kao Bjelovarsko-križevačka županija. Danas se pak sva tri spomenuta kotara nalaze gotovo cijela u sastavu Koprivničko-križevačke županije, te nas je to i ponukalo da donesemo prvi poimenični popis obrtnika na tom području 1890. godine. Smatrajući Austro-ugarsku nagodbu definitivnom podjelom Habsburške Monarhije na dva dijela, Mađari su područja koja su došla pod njihovu upravu smatrali svojim teritorijem te su kroz pola stoljeća Nagodbe činili sve da ta područja što više mađariziraju negirajući postojanje Pragmatičke sankcije iz 1712. koja je Hrvatskoj osiguravala posebnu autonomiju 
i zaštitu Bečkog dvora. Mađari su mađarizaciju provodili preko gospodarstva i financija te željeznica, koje su sada svoje polazište imale u Budimpešti, a ne više u Beču, a na kojima je službeni jezik bio isključivo mađarski. Željeznička pruga Nagykanizsa - Koprivnica - Zagreb - Karlovac - Rijeka izgrađena je u rekordnom roku do 1873. godine te je na te poslove privukla mnoštvo tehničkog službenog osoblja, uglavnom Mađare i Kranjce, ali i Moravce i osobito Čehe. Tako je počela velika imigracija stručnjaka raznih vrsta na područje Koprivnice i Križevaca, koji su gradovi imali stanicu ne samo za prijam putnika već i za ukrcaj i iskrcaj raznih roba. Najkraći put iz srednje Europe prema moru bio je sada otvoren preko Koprivnice i njime su krenuli obrtnici i trgovci prema jugu otvarajući obrtne i trgovačke radnje gdje je god za to bilo mogućnosti i potrebe. Neke željezničke stanice, kao Gradec i Mučna Reka, podignute su tek kasnije ne samo zbog ukrcaja ljudi već i zbog apatovačke vode te mesnih proizvoda, drva, ugljena i brašna, što se sve slalo u Rijeku, jer se pokazalo da su i ti krajevi proizvodnog karaktera. Radi opskrbe željeznice ugljenom, otvara se i nekoliko rudnika između Koprivnice i Križevaca, a rudari svojom zaradom utječu na otvaranje trgovinica i krčmi. ${ }^{1}$ Upravo zbog svojeg trgovačkog karaktera, Rijeka je i uvrštena u Adresar, iako je bila grad pod direktnom upravom Ugarske. Stanica Dugo Selo otvorena je tek 1897. preusmjerivši promet s pruge Južnih željeznica Zagreb - Sisak - Novska. Na prugu Koprivnica - Križevci priključuje se 1894. i pruga Križevci - Bjelovar, kao vicinalna pruga, dajući veću važnost zbližavanju Bjelovara s Mađarskom preko Koprivnice nego sa Zagrebom, iako je Zagreb već bio kulturni, prometni, obrazovni, crkveni i upravni centar Hrvatske. ${ }^{2}$

Do Zakona o radnjama 1884. obrtne i trgovačke radnje otvarale su se stihijski, bez ikakve provjere, te je vladao veliki nered jer su radnje osnivane bez kontrole zagrebačke Trgovačko-obrtničke komore. Bilo je dovoljno skupiti potrebni kapital. Veću ulogu imao je samo Obrtni zbor u Koprivnici i Križevcima u kojem su novi obrtnici polagali ispite za zvanja za koja je bio potreban ispit. Počele su se osnivati i prve šegrtske škole, ali je i dalje bio u prednosti obrtnik, odnosno kalfa, koji je svoje naukovanje izučio kraćim ili duljim usavršavanjem u inozemstvu ili je bio strani imigrant koji je taj kraj odabrao za svoje stalno mjesto boravka i rada. ${ }^{3}$

Popis koji objavljujemo za područje današnje Koprivničko-križevačke županije odnosi se na vrijeme kad se uprava počela bolje sređivati te su županije,

Vladimir MILIVOJEVIĆ, Reka: povijest, priče, ljudi, Koprivnica, 2018., 140-141.

2 Branko VUJASINOVIĆ, Upravno i poslovno osoblje na željeznicama u Kraljevini Hrvatskoj i Slavoniji do 1918., Zagreb, 2007., 386 i 391.

3 Ružica MEDVARIĆ-BRAČKO, Mira KOLAR-DIMITRIJEVIĆ, Šegrtska škola u Koprivnici od 1886. do 1900 godine, Podravski zbornik, 42, Koprivnica, 2017., 101-122. 
gradske općine i škole morale podnositi redovne izvještaje. Ban Khuen-Héderváry, sklon brojčanom iskazivanju stanja, nastojao je brojnošću obrtnika i trgovaca u Hrvatskoj opovrgnuti tvrdnju hrvatskih političara da Hrvatska zaostaje za Mađarskom na gospodarskom planu. Dakako da je tome pogodovao i potres u Zagrebu 1880., koji je privukao pažnju velikog broja obrtnika iz čitave Monarhije na područje Zagreba i okolice, kamo se lagano i brzo stizalo novoizgrađenom željezničkom prugom.

Popis obrtnika i trgovaca iz 1890. jedini je poimenični popis koji imamo u drugoj polovici 19. stoljeća za sjevernu Hrvatsku, odnosno područje zagrebačke Trgovačke i obrtničke komore i Rijeku, ali u ovom radu donosimo samo popis za tri kotara: Koprivnički, Križevački i Đurđevački, razdvajajući obrtnike iz središta kotara od obrtnika po selima i manjim mjestima.

\section{O Adresaru obrtnog i poslovnog svieta u Hrvatskoj g. 1890.}

Gjuro (Georgius) Justić i Ljudevit (Ludwig) Strohmayer, činovnici Trgovačko-obrtničke komore u Zagrebu, osnovane 1852. godine, sastavili su 1890. i objavili 1891. prvi Adresar obrtnog i poslovnog svieta u Hrvatskoj g. 1890. na hrvatskom i njemačkom jeziku po nalogu bana Khuen-Héderváryja. Treba upozoriti da, iako je sastavljen 1890. po službenim izvorima i po nalogu vlade, brzina kojom su ga izradila svega dva stručnjaka odražava se u njegovoj kvaliteti, to jest u nepažljivu pisanju prezimena, čestom ispuštanju pisanja punih imena obrtnika i trgovaca, pa ne znamo radi li se o muškoj ili ženskoj osobi, a vjerojatno i utvrđivanju lokacije rada. Adresar obuhvaća samo prostor zagrebačke Trgovačko-obrtničke komore, pa, kada bismo i evidentirali sve obrtnike na području zagrebačke Trgovačke i obrtničke komore, ne bismo mogli izvršiti usporedbu s prostorom osječke Komore, čija je struktura obrtnika i trgovaca, zbog različitosti kupaca, bila znatno drugačija. Naime budimpeštanska vlada drugačije se odnosila prema Slavoniji i Srijemu, a njezine tri županije Mađari su tretirali kao dio svojeg užeg teritorija koji se nalazi u procesu pojačane mađarizacije, koja je u mnogo slabijoj mjeri zahvatila područje zagrebačke Trgovačko-obrtničke komore. Tu je bilo mnogo malih gradova s još više malih sela i zaselaka nastanjenih seljacima s malim zemljišnim posjedima (Grundherschaft) koji su tek koje desetljeće prije izašli iz statusa kmetova ili krajišnika. U Slavoniji nalazimo pak velike posjede u rukama stranog plemstva (Gutsherschaft), kupljene ili dobivene za ratne i upravne zasluge Bečkom dvoru u doba apsolutizma, koji su tijekom krize započete 1873. sve više prelazili u ruke stranih modernih gospodarstvenika koji podižu tvornice na bazi iskorištavanja domaćih sirovina, plodne zemlje i jeftine radne snage nadničara. 
O cehovima imamo dosta brojnu literaturu koja je nastajala tijekom 20. stoljeća iz pera povjesničara, geografa i ekonomista te istraživača lokalne povijesti. No radovi o obrtima i obrtnicima malobrojniji su i uglavnom su rezultati istraživanja ubačenih u lokalne monografije, kojih je do danas izašlo vrlo mnogo. Za područje kojim se bavi ovaj rad najrelevantniji primjer takvog odnosa jest monografija Podravina akademika Dragutina Feletara (Koprivnica, 1973.), koji u tom radu navodi autore koji su pisali o gospodarstvu prije njega. ${ }^{4}$ Međutim invenziviranje povijesno-ekonomskih istraživanja na području sjeverozapadne Hrvatske poslije toga proširilo je naše spoznaje i danas već rijetko možemo naći neki dio ekonomske povijesti današnje Koprivničko-križevačke županije koji nema svojeg istraživača, ali je i taj proces još u tijeku, pa nam nedostaje prostora da nabrojimo relevantne pisce o razvoju gospodarstva. Obrtnici su preuzeli ulogu čuvara proizvodne tradicije, ali su bili i pokretači napretka i danas ne možemo zamisliti razvoj nekog kraja bez njihova udjela.

\section{Teritorij i struktura Koprivničkog, Križevačkog i Đurđevačkog kotara 1903. godine.}

Adresar obrtnog i poslovnog svieta u Hrvatskoj iz 1891. obuhvaća područje tadašnje Varaždinske, Bjelovarsko-križevačke, Zagrebačke, Modruško-riječke i Ličkokrbavske županije te Rijeke, dakle i područje senjske Trgovačko-obrtničke komore, a objavljen je na hrvatskom i njemačkom jeziku. U predgovoru Adresara J.Z.G. njegovo objavljivanje uoči Milenijske izložbe 1891. ukazuje na razloge njegova izdavanja, $\mathrm{tj}$. ukazivanje posjetiteljima u Zagrebu na činjenicu da naše područje, a osobito Zagreb, ima ne samo vrlo povoljan zemljopisno-trgovački položaj koji, s obzirom na mirno stanje u zemlji, mora utjecati na razvoj obrta i trgovine. Da bi to dokazao, poslije predgovora nakladnika iz svibnja 1892. neki J.Z.G. piše u Adresaru detaljno o gradu Zagrebu i njegovoj okolici, ali, nažalost, nema takvog osvrta za kotare. Adresar je nastao u kratkom vremenu od studenoga 1890., kada je oglasom pozvan obrtno-trgovački svijet da se prijavi za Adresar, a već u svibnju 1891. Adresar je bio pripremljen za tisak.U Adresaru je najavljena i stalna evidencija obrtnika i trgovaca vođenjem posebnih knjiga, ali na osnovi svojih istraživanja znam da su te knjige vođene vrlo neuredno i nisu siguran pokazatelj početka rada, a još više završetka djelatnosti obrtnika i trgovaca. Privredni registri na okružnim sudovima nešto su točniji, ali mnogi obrtnici rade ilegalno te se, kao seljaci, ne prijavljuju

4 Dragutin FELETAR, Hrvoje PETRIĆ, Bibliographia Podraviana: izbor literature o Podravini, knjiga I, izd. Hrvatski zemljopis i Naklada dr. Feletar, Koprivnica, 2001., D. FELETAR, Podravina. Prinos poznavanju gospodarskog razvoja sjeverozapadne Hrvatske, Koprivnica, 1973. 
kao obrtnici, pa nam Adresar, koji je trebao biti reklamiran na Izložbi 1893., pruža prvi - vjerojatno najobuhvatniji - popis obrtnog i trgovačkog svijeta na području zagrebačke Trgovačko-obrtničke komore. U ovom radu iskazani su samo obrtnici iz Koprivničkog, Križevačkog i Đurđevačkog kotara, koji većim dijelom danas pripadaju Koprivničko-križevačkoj županiji.

Područje Koprivničkog, Križevačkog i Đurđevačkog kotara opstojalo je 1886. - 1924. u Bjelovarsko-križevačkoj županiji, nakon čega se osnivaju oblasti; danas pripada Koprivničko-križevačkoj županiji. Na tom je području u razdoblju 16. 18. stoljeća pripremana i vođena obrana od Osmanlija, ali su se i prije i kasnije osjećali utjecaji i istoka i zapada, stoga su tamošnje stanovništvo i jezik bili podvrgnuti dugotrajnom stranom utjecaju. Dio tog teritorija bio je pod vojnom upravom Štajerske u Grazu, a onda Varaždinskoga generalata, ali su stari gradovi Koprivnica i Križevci zadržali i dio svojega posebnog statusa slobodnoga grada. U njima su cehovi predstavljali glavni oblik opskrbe stanovništva, uz proizvode koje su donosili u grad seljaci, koji su se od vremena Josipa II. mogli slobodno kretati, pa i učiti neke obrte, iako ni Koprivnica ni Križevci nisu nikada imali status komuniteta. Sposobnost stanovništva da samo pokriva svoje lokalne potrebe utjecala je na početak osnivanja brojnih malih obrtničkih radionica vrlo brzo nakon završetka razvojačenja, a dolaskom židovskih trgovaca nastaju u mnogim mjestima i male trgovine. Burna povijest ostavila je snažan trag na tom području, na kojem su se vodili ratovi, ali čiji su stanovnici bili tijekom 18. i 19. stoljeća uključeni u ratove koje je Habsburška Monarhija vodila sa svojim susjedima.

Vrijeme kada je objavljen Adresar bilo je vrijeme mira koje je tijekom pola stoljeća omogućilo relativno miran razvoj, ali su zbivanja na gospodarskom planu bila itekako vehementna dovodeći do brzih promjena i česte izmjene gospodarskih subjekata. Sastav Adresara pada u vrijeme završetka krize koju je uzrokovao financijski slom na bečkoj burzi. Posljedica toga bilo je nepovjerenje u rad dioničkih društava, uzrokovano slomom mnogih plemićkih posjeda, jer su ta društva sredstva dobivena odštetom za urbarsku zemlju uložila u neprovjerene dionice. Sve je to dovelo do velikih promjena te je područje naših triju kotara postalo privlačno za imigraciju stranih obrtnika i trgovaca, ali i nastavak procesa podjele društva na osnovi imovinskog statusa, koji je bio presudan kao i nesmiljena konkurencija, ali i za uključivanje i u sve razvijeniji politički i stranački život.

Na području Zagrebačke trgovačko-obrtničke komore stranci su primani srdačno i bez većih otpora; to je podržavala i Zemaljska vlada u Zagrebu, ali i ministarstva u Budimpešti koja su bila zadužena za gospodarstvo, financije i promet. Preko službenog jezika na željezničkoj pruzi Mađarska - Rijeka Mađari su jačali svoj utjecaj, koji se sudarao s austrijskim, odnosno kranjskim utjecajem, 
koji je dolazio preko Južnih željeznica na trasi Budimpešta - Trst. Nalazeći se u tom procijepu, naša tri kotara bila su konačni cilj mnogih obrtnika i trgovaca, koji su svojim znanjima i spoznajama pridonijeli da se taj kraj počeo ubrajati među najnaprednije dijelove tadašnje Hrvatske i Slavonije, koje je područje tek 1902./3., zahvaljujući braći Radić, izrazilo svoje nezadovoljstvo vladom u rukama Mađara. Na proces modernizacije blagonaklono su gledali i Beč i Pešta nastojeći se rasteretiti viška svojeg židovskog stanovništva, ali i zauzeti dominantne pozicije na željezničkoj pruzi prema Rijeci, koja se razvijala kao glavna i velika mađarska luka. U taj proces vrlo su se uspješno uključili i Kranjci - Slovenci zahvaljujući srodnosti slovenskog jezika s kajkavskim jezičnim izrazom.

Prema Statističkom godišnjaku I, Zagreb, 1905., u Koprivničkom kotaru živjelo je 1890. godine 28.067 stanovnika, a u gradu Koprivnici 6.512; u razdoblju 1869. - 1890. broj stanovnika u kotaru povećao se za 6.816 osoba, a u gradu za 839 osoba. Treba upozoriti da su podaci za 1869. godinu izračunati računski, jer te godine nije rađen popis stanovništva u Hrvatskoj i Slavoniji te nam je to vrijeme do 1880., odnosno 1890., statistički najslabije popisano. ${ }^{5}$

$\mathrm{U}$ tom razdoblju izvršene su znatne promjene upravnog ustroja. Koprivnička podžupanija, koja se prije nalazila u Križevačkoj županiji, sada je podijeljena na kotare Koprivnicu i Đurđevac, koji su ušli u Bjelovarsku županiju, oformljenu 1886. godine, a nakon spajanja s Križevačkom u Križevačko-bjelovarsku županiju sa središtem u Bjelovaru. Zbog izoliranosti Bjelovara od željeznice sve do 1894. godine, Koprivnica je - kao prvo mjesto na desnoj obali Drave s jedinim mostom nakon što se most kod Osijeka srušio zajedno s vlakom - postala glavna veza Zagreba s Mađarskom, ali i s Rijekom. Jačaju njezine trgovačke i gospodarske funkcije. Koprivnica dobiva zadaće koje joj uvećavaju gospodarsku vrijednost. U kotar su ušla i neka mjesta ranije Križevačke i Đurđevačke pukovnije nakon razvojačenja, a trgovci i obrtnici s tog područja, pa i iz Prigorja, počinju Koprivnicu smatrati svojim gravitacijskim središtem zbog željezničke stanice. Drnje i Legrad, gdje su se u vrijeme Vojne krajine nastanili mnogi židovski trgovci, sada su se - zbog izjednačenja materijalnih prava s ostalim stanovništvom 1873. - počeli preseljavati u Koprivnicu i tamo svojim kapitalom poticati razvoj trgovine i ugostiteljstva.

Prema statistici 1769. - 1869., grad Koprivnica ubrzano se širio i broj stanovnika povećao se s 2.589 na 5.684, s time da je u tom vremenu u gradu nestalo $92 \%$ prijašnjih prezimena, a novih je bilo $91 \%$, što znači da je došlo do velikog useljavanja novog stanovništva sa svih strana. ${ }^{6}$

Statistički godišnjak kraljevina Hrvatske i Slavonije, I, Zagreb, 1905., dzt. 4 i 30.

6 Hrvoje PETRIĆ, Koprivnica na razmeđi epoha (1765-1870), Izd. kuća Feletar i Zavod za hrvatsku povijest Odsjeka za povijest FF u Zagrebu, Koprivnica - Zagreb, 2000., 82. 
Statistički ured u Zagrebu objavio je 1905. godine povećanje broja stanovništva 1869. - 1890. na području Hrvatske i Slavonije. Prema tom izboru, stanovništvo Kotara Koprivnice poraslo je u tom vremenu od 21.251 na 28.067, a grada od 5.683 na 6.513, stanovništvo Križevačkog kotara od 34.444 na 36.449, a grada od 3.229 na 3.665, dok je stanovništvo Kotara Đurđevca poraslo od 34.439 na 55.769 stanovnika.?

Popisi stanovništva u drugoj polovici 19. stoljeća obavljali su se neredovito i neuredno, pa je popis koji je slijedio nakon onog 1857., u vremenu bana Josipa Jelačića, proveden na terenu tek 1880.; no kako je vođen po drugim kriterijima, nije moguće napraviti komparaciju za obrtnike i trgovce. Stanovništvo Hrvatske i Slavonije činilo je 1880 . godine $75,6 \%$ stanovništva koje je obitavalo na području Hrvatske, Slavonije, Dalmacije i Istre, te je na tom području stanovništvo raslo nešto brže nego na području Dalmacije i Istre. Jakov Gelo zaključuje da je to posljedica ne samo prirodnog rasta već još više pojačane imigracije, koja se nastavila i sljedećih godina. ${ }^{8}$ Podatke o proizvodnim zanimanjima zanemaruje prvi moderni građanski popis iz 1857., kao što to vidimo iz monografije dr. Petra Korunića, koji je godinama radio na popisima stanovništva uočivši nedorečenost dotadašnjih istraživanja. ${ }^{9}$ Razloge tome treba tražiti u podređenosti Hrvatske Beču, problematičnom statusu Hrvatske, koja se stalno dijelila i komadala i kojoj se negirala sposobnost da i nakon spajanja svih djelova bude samoodrživa zemlja, pa je 1868. dobila podređeni položaj u ugarskom dijelu Monarhije. To su osjećali i ondašnji gospodarstvenici, pa je u Beču pokrenut dugovječni Compas, a u Pešti istovrsni informator; izlazili su do 1943., ali su podaci za Hrvatsku manjkavi. ${ }^{10} \mathrm{Ni}$ Trgovačko-obrtnička komora u Zagrebu, osnovana 1852., nije ispunila svoju zadaću zbog slabog financiranja, iako je tajnik komore Imbro Ignjatijević Tkalac sastavio nekoliko posebnih izvještaja o stanju gospodarstva, pa je onda nezadovoljan i napustio Hrvatsku. ${ }^{11}$

Ipak, na osnovi djelomičnih popisa možemo vidjeti da stanovništvo sva tri naša kotara pokazuje pozitivan rast - očito su postojali povoljni socijalni i gospodarski, ali i zdravstveni uvjeti. Pri tome grad Koprivica pokazuje veći rast nego grad Križevci, što je vjerojatno posljedica toga što je Koprivnica bila prvo mjesto za iskrcaj i utovar robe na željeznicu s desne strane Drave, odakle se pro-

Statistički godišnjak kraljevina Hrvatske i Slavonije, I, Zagreb, 1905., str. 4.

8 Ivan GELO, Demografske promjene u Hrvatskoj od 1780. do 1981. g., Globus, Zagreb, 1987., 101.

9 Petar KORUNIĆ, Naselja i stanovništvo hrvatskih pokrajina 1750.-1870., 1, Zagreb, 2019., 13 i 17.

10 Mira KOLAR-DIMITRIJEVIĆ, Ekonomski podaci o gospodarstvu Hrvatske do 1945. godine. (Compassi). Acta historico-oeconomica, sv. 22, 1995., 35-54.

11 Imbro IGNJATIJEVIĆ TKALAC, Hrvatsko gospodarstvo polovicom XIX. stoljeća. Izvještaji carsko-kraljevskom ministarstvu u Beču, Zagreb, 2004. 
metovalo i prema Đurđevcu i Ludbregu. Križevci su željezički spoj s Bjelovarom dobili tek 1894., a s Varaždinom nikada, s time da su 1886. izgubili status županijskog središta. Godine 1895. i Koprivnica i Križevci izgubili su status povlaštenih kraljevskih gradova, što su na području Hrvatske i Slavonije zadržali samo Zagreb, Varaždin, Osijek i Zemun.

Svakako je zanmljiva upavna struktura naša tri kotara. Oni se znatno razlikuju, kako se to može iščitati iz tablica $1-3$ koje je sastavio Zemaljski statistički ured u Zagrebu 1903. godine. Iako ima razlika u odnosu na Adresar iz 1890. godine, a još više u odnosu na područje današnje Koprivničko-križevačke županije, šteta je što nemamo katalog obrtnika i trgovaca kakav je sastavljen za kulturnu baštinu Podravine i Prigorja 2001. godine. ${ }^{12}$

Tablica 1. Upravna struktura Koprivničkog kotara 1903. godine*

\begin{tabular}{|l|c|c|c|c|c|c|c|}
\hline \multicolumn{1}{|c|}{$\begin{array}{c}\text { Grad ili } \\
\text { upravna općina }\end{array}$} & Km $^{2}$ & $\begin{array}{c}\text { Broj } \\
\text { stanovnika }\end{array}$ & \multicolumn{5}{|c|}{ Prebivalište } \\
\hline & & & Gradovi & Sela & Majuri & Zaseoci & Ukupno \\
\hline Grad Koprivnica & 62 & 7.078 & 1 & 1 & 1 & - & 2 \\
\hline U. o. Drnje & 45 & 3.586 & & 2 & & 4 & 6 \\
\hline U. o. Gola & 62 & 5.112 & & 3 & & 5 & 9 \\
\hline U. o. Hlebine & 46 & 3.017 & & 2 & & 11 & 13 \\
\hline $\begin{array}{l}\text { U. o. Novi Grad } \\
\text { Podravski }\end{array}$ & 91 & 6.556 & & 10 & & 1 & 11 \\
\hline U. o. Peteranec & 27 & 2.642 & & 2 & & & 2 \\
\hline U. o. Sokolovac & 199 & 8.650 & & 35 & & & 35 \\
\hline Ukupno & $\mathbf{5 3 2}$ & $\mathbf{3 6 . 6 4 1}$ & $\mathbf{1}$ & $\mathbf{5 5}$ & $\mathbf{1}$ & $\mathbf{2 1}$ & $\mathbf{7 8}$ \\
\hline
\end{tabular}

* „Političko, sudbeno i financijalno razdieljenje i repertorij prebivališta Kraljevina Hrvatske i Slavonije po stanju 1. travnja 1903.", Statistički godišnjak kraljevina Hrvatske i Slavonije I., Zagreb, 1905., str. 2, i posebno izdanje Zagreb, 1903.

Iz tablice 1 vidimo da je grad Koprivnica bio središte velikog kotara, ali da ni po površini ni po broju stanovnika nije bio poseban te da ga je po broju stanovnika nadmašivala Upravna općina Sokolovac. Na temelju ispisa imena obrtnika iz Adresara iz 1891. saznajemo da je broj obrtnika u kotaru bio čak nešto veći nego u gradu Koprivnici te da su samo trgovci asortimanom roba kojima su trgovali nadmašivali trgovce iz grada. Željeznička pruga otvorena 1870. omogućila je Koprivnici brži razvitak, pogotovo stoga što se vlak nije zaustavljao u manjim

12 Podravina i Prigorje. Kulturna i prirodna baština. Izd. Koprivničko-križevačke županije, Koprivnica, 2001., katalog na kraju knjige. 
mjestima između Koprivnice i Križevaca, kao ni između Križevaca i Zagreba, pa se sav utovar teretne robe morao obavljati preko Koprivnice, uključivši i područje od Koprivnice prema Varaždinu, odnosno prema Đurđevcu, koji nisu bili vezani željeznicom. Uočava se dobra naseljenost Prekodravlja, koje je vezano na željezničku mrežu u Mađarskoj preko Gole u Prekodravlju i koje su područje Mađari smatrali svojim; to se osjetilo na benefitima koji su taj kraj učinili naprednim i relativno bogatim. Obrtnici su se teško organizirali nakon ukidanja cehova. Austrijski Obrtni zakon iz 1871. nije dobro prihvaćen, ali ni novi mađarski Zakon o radnjama iz 1884. nije zadovoljio naše trgovce i obrtnike, iako se primjenjivao sve do Zakona o radnjama iz 1931. Na poziv zagrebačke Trgovačko-obrtne komore održana je 1891. Druga obrtnička skupština u Zagrebu. Njoj su uime Trgovačkog zbora iz Koprivnice prisustvovali trgovci David Deutsch i Ignaz Schwarz, što pokazuje da su u Koprivnici židovski trgovci već imali veću važnost od obrtnika, koji nisu imali svojeg predstavnika, iako su bili brojniji. Stoga je 1903. i osnovan Savez hrvatskih obrtnika, koji je sve do Drugoga svjetskog rata imao važnu ulogu za rad domaćih obrtnika.

Prema Adresaru, Gola je pripadala Koprivničkom kotaru, Ždala je pak bila uvrštena u Đurđevački kotar. Možda su upravo tom politikom podjele Mađari poticali gravitiranje stanovništva na tom području prema gospodarski uređenijoj Mađarskoj, koja je poslije 1848. znatno unaprijedila svoje cjelokupno gospodarstvo, povrativši time svoju važnost i politički ugled od prije 1848. godine, što je i utjecalo na kralja Franju Josipa da poslije dva ratna poraza pristane podijeliti s Mađarima carstvo. Za Prekodravlje, koje je nemirna Drava prebacila u prošlosti na lijevu obalu Drave, vodile su se dugo oštre polemike - ono je tek 1920., kao i Međimurje, dodijeljeno Kraljevstvu Srba, Hrvata i Slovenaca, odnosno monarhističkoj Jugoslaviji, na osnovi sastava stanovništva. ${ }^{13} \mathrm{~A}$ bilo je to presudno i za Međimurje. Upravna općina Đelekovec i Legrad nisu 1891. pripadali Koprivničkom već Ludbreškom kotaru, čiji će popis obrtnika biti - kako se nadamo - objavljen u 39. broju časopisa Podravina.

Križevački kotar bio je teritorijem mnogo veći od Koprivničkog kotara i imao je mnogo rastresitiju strukturu, s više zaselaka smještenih na brdovitom terenu Prigorja, ali su tamo postojali i majuri u vlasništvu preživjelog plemstva ili crkve. Svakako je na strukturu stanovništva na tom području djelovalo to što je on bio do 1886. županijsko središte sa svim popratnim institucijama, uključivši posebno Ratarnicu i gospodarsko učilište, osnovano 1860., koje je do 1891. imalo i Šumarski odjel. Zbog svoje opozicijske politike, Križevci nisu bili u milosti bana Khuen-

Mira KOLAR-DIMITRIJEVIĆ, Ante Trumbić i borba za dravsku granicu na pariškoj mirovnoj konferenciji. Zbornik: Život i djelo Ante Trumbića, Zagreb, 1991., izd. JAZU, 91-103; Ivan VEČENAJ-TIŠLAROV, Mojemu zavičaju. Prekodravlje u povijesti, legendi i priči. IV, Gola, 1992., 9-121. 
Héderváryja, pa se to odrazilo na svim područjima života, a osobito na zanemarivanju velikih upravnih općina u Vrbovcu i Gradecu, koji su malo-pomalo više gravitirali Zagrebu nego Križevcima te danas pripadaju Zagrebačkoj županiji, što se mora uzeti u obzir kod iščitavanja zaključaka ovog rada. Kao županijsko središte, Križevci su u odnosu na Koprivnicu bili bogatiji crkvenim i kulturnim ustanovama, na što svakako djeluju i ruševine kalničkoga grada, ali i Apatovačka voda; a tu se već razvio i turizam zahvaljujući planinarenju Križevčana i Zagrepčana, a Križevački štatuti njegovali su tradiciju kalničkih šljivara. Križevci su imali manufakture još u 18. stoljeću, a velik utjecaj imala je i Križevačka ratarica, odnosno gospodarska škola koju su vodili stručnjaci iz Moravske i Češke donoseći spoznaje iz tih najrazvijenijih slavenskih regija u srednjoj Europi. U tom je gradu djelovao i u to vrijeme ugledni dr. Franjo Marković. Križevci su imali i vrlo razvijeni muzički život zahvaljujući svojoj eliti, među kojom je bilo i više pjevača i glumaca svjetskoga glasa. U Križevcima se njegovalo svilarstvo, a Grkokatolička biskupija dala im je značaj crkvenog središta. Tamo je svoju knjižaru otvorio već i Gustav Neuberg. Institut za povijest umjetnosti Sveučilišta u Zagrebu objavio je 1993. detaljnu umjetničku topografiju grada Križevaca i njegove okolice u kojoj najbolji stručnjaci opisuju ne samo crkvenu već i profanu arhitekturu u gradu i mnogim mjestima u kojima su živjeli obrtnici Križevačkoga kotara 1890. godine. ${ }^{14}$

Tablica 2. Upravna struktura Križevačkog kotara 1903. godine*

\begin{tabular}{|l|c|c|c|c|c|c|c|}
\hline \multicolumn{1}{|c|}{$\begin{array}{c}\text { Grad ili } \\
\text { upravna općina }\end{array}$} & Km $^{2}$ & $\begin{array}{c}\text { Broj } \\
\text { stanovnika }\end{array}$ & \multicolumn{5}{|c|}{ Prebivalište } \\
\hline & & & Gradovi & Sela & Majuri & Zaseoci & Ukupno \\
\hline Grad Križevci & 38 & 4.408 & 1 & 4 & - & - & 5 \\
\hline U. o. Gradec & 37 & 2.588 & - & 8 & - & - & 9 \\
\hline U. o. Raven & 114 & 7.832 & - & 36 & - & 7 & 43 \\
\hline $\begin{array}{l}\text { U. o. Sveti Ivan } \\
\text { Žabno }\end{array}$ & 122 & 7.336 & - & 22 & 3 & - & 25 \\
\hline $\begin{array}{l}\text { U. o. Sveti Petar } \\
\text { Orehovec }\end{array}$ & 114 & 8.815 & - & 36 & 2 & 3 & 41 \\
\hline U. o. Vojakovec & 191 & 10.510 & - & 24 & - & 18 & 42 \\
\hline U. o. Vrbovec & 200 & 12.536 & - & 41 & 5 & 6 & 32 \\
\hline Ukupno & $\mathbf{8 1 6}$ & $\mathbf{5 4 . 0 2 5}$ & $\mathbf{1}$ & $\mathbf{1 7 1}$ & $\mathbf{1 0}$ & $\mathbf{3 4}$ & $\mathbf{2 1 6}$ \\
\hline
\end{tabular}

* Političko i sudbeno razdieljenje i repertorij prebivališta Kraljevina Hrvatske i Slavonije po stanju 1. travnja 1903., Zagreb 1903, str. XIV-XVI.

${ }_{14}$ Križevci, grad i okolica, Institut za povijest umjetnosti Sveučilišta u Zagrebu (ur. Žarko Domljan), Zagreb, 1993., 281-392. Vidjeti i topografsku kartu na str. 9. 
Đurđevački kotar bio je veličine prva dva kotara. Imao je samo vojničku tradiciju kao sjedište Đurđevačke pukovnije, iako je, zbog praktičnosti, njezino središte bilo u Bjelovaru. Đurđevac nije bio grad već trgovište, a isti status imalo je i obližnje Virje. Ta dva mjesta dijelila su mnoge važne funkcije, od regulacije vodotokā pa do obrtnika, koji su, podijeljeni u tri skupine, zadovoljavali potrebe sveg stanovništva. Pritom je Virje, zahvaljujući ilircu Ferdi Rusanu, do 1871. imalo i svoju bratovštinu koja je njegovala važne poljoprivredne grane na temeljima dostignuća tadašnje poljodjelske struke, ne zanemarujući ni svilarstvo.

Tablica 3. Upravna struktura Đurđevačkog kotara 1903. godine*

\begin{tabular}{|l|c|c|c|c|c|c|c|c|}
\hline $\begin{array}{c}\text { Upravna } \\
\text { općina }\end{array}$ & Km $^{2}$ & $\begin{array}{c}\text { Broj } \\
\text { stanovnika }\end{array}$ & \multicolumn{5}{|c|}{ Prebivalište } \\
\hline & & & Gradovi & Trgovišta & Sela & Majuri & Zaseoci & Ukupno \\
\hline Đurdevac & 173 & 13.812 & - & 1 & 5 & & 21 & 27 \\
\hline Ferdinandovac & 35 & 2.339 & & & 1 & & 16 & 17 \\
\hline Kloštar & 78 & 5.903 & & & 6 & & 1 & 7 \\
\hline Molve & 45 & 3.836 & & & 1 & & 6 & 7 \\
\hline Pitomača & 121 & 9.100 & & & 7 & 2 & 9 & 18 \\
\hline $\begin{array}{l}\text { Sesvete } \\
\text { Podravske }\end{array}$ & 29 & 2.760 & & & 1 & & 3 & 4 \\
\hline Virje & 125 & 11.937 & & 1 & 5 & & 14 & 20 \\
\hline Ukupno & $\mathbf{6 0 6}$ & $\mathbf{4 9 . 5 8 7}$ & & $\mathbf{2}$ & $\mathbf{2 6}$ & $\mathbf{2}$ & $\mathbf{7 0}$ & $\mathbf{1 0 0}$ \\
\hline
\end{tabular}

* Političko i sudbeno razdieljenje i repertorij prebivališta Kraljevina Hrvatske i Slavonije po stanju 1. travnja 1903., Zagreb, 1903., str. XIV-XV.

Iz tablica 1 - 3 vidimo da je Križevački kotar 1890. bio najveći - i po površini, i po broju stanovnika, i po broju naselja, što je rezultat toga što je do 1886. bio županijsko središte, ali i što je obuhvaćao mjesta koja su se već razvijala pod utjecajem Zagreba (Gradec, Vrbovec) te plodne, nikada plavljene krajeve na padinama Kalnika. Protežući se na $1.958 \mathrm{~km}^{2}$, na tom su prostoru u 394 naseljena mjesta živjela 140.053 stanovnika. Najslabije naseljeni bio je Koprivnički kotar, ali je grad Koprivnica sa svojih 7.000 stanovnika pokazivao da preuzima vodeću ulogu u širem području, zahvaljujući željeznici, ali i tome što je bio cestovno raskrižje prema Varaždinu i Đurđevcu, preuzimajući dio poslova toga trgovišta. 


\section{Obrtnici u gradu Koprivnici 1890. godine.}

O cehovima u Koprivnici imamo dosta brojnu literaturu koja je nastajala tijekom 20. stoljeća, ali je povijest obrta i trgovine u drugoj polovici 19. stoljeća još obrađena selektivno. U toj se literaturi tako navode pojedini gospodarstvenici koji su stekli kapital i donijeli odluku o iskorištavanju novoizgrađenih željezničkih pruga te osnovali svoje radnje iskoristivši i iskustvo već zamrlih cehova i vještih pojedinaca koji su se bavili obrtom po selima.

Tablica 4. Popis obrtnika u gradu Koprivnici 1890. te broj obrtnika i ukupno*

\begin{tabular}{|c|c|c|c|c|}
\hline \multirow{2}{*}{$\begin{array}{l}\text { Obrtnici po } \\
\text { vrstama }\end{array}$} & \multirow[t]{2}{*}{ Ime i prezime } & \multicolumn{3}{|c|}{ Broj obrtnika } \\
\hline & & Grad & Kotar & Ukupno \\
\hline Bačvari & $\begin{array}{l}\text { Branilović Blaž, Pizner Franjo, Samobor Ana, } \\
\text { Turković Franjo, Turković Vjekoslav }\end{array}$ & 5 & 4 & 9 \\
\hline Bravari & $\begin{array}{l}\text { Brozović Franjo, Cibulić Ivan, Hunjak Miško, } \\
\text { Ivančić Janko, Levanić Mio, Majdak Andro, } \\
\text { Rosčan Petar, Šavor Nikola }\end{array}$ & 8 & - & 8 \\
\hline Brijači & $\begin{array}{l}\text { Ester Franjo, Hranilović Nikola, Jagodić Maria, } \\
\text { Peroković Ignac, Sabadi Valent, Štefanić } \\
\text { Eduard }\end{array}$ & 6 & 1 & 7 \\
\hline Brusari & Flossberger Ivan & 1 & - & 1 \\
\hline Češljari & Pevalek Mirko & 1 & - & 1 \\
\hline Čizmari & $\begin{array}{l}\text { Andrašek Ivan, Antolković Adam, Antolković } \\
\text { Mio, Čapo Josip, Čapo Pavao, Fištrović Imbro, } \\
\text { Fištrović Josip, Gašparić Antun, Gutić Stjepan, } \\
\text { Habunek Andro, Igrić Imbro, Igrić Stjepan, } \\
\text { Ipša Stjepan, Kamenar Ignac, Kolarić Franjo, } \\
\text { Kuzmić Vid, Marin Franjo, Medjeral Mio, } \\
\text { Mikulčić Gjuro, Mikulec Stjepan, Petrinić Luka, } \\
\text { Pišćak Ignac, Pišćak Tomo, Puškadija Andro, } \\
\text { Sabolić Stevo, Savorić Josip, Šolčić Josip, } \\
\text { Štefović Mato, Svastnik Antun, Tkalčec Joso, } \\
\text { Toplak Josipa, Vati Stjepan, Vartić Vatroslav, } \\
\text { Vidačić Bolto, Vlahinja Mato, Zaiček Stjepan }\end{array}$ & 36 & 4 & 40 \\
\hline Čohaši & Jambrić Mato & 1 & - & 1 \\
\hline Dimnjačari & Čuber Gašpar, Matijašić Marko & 2 & - & 2 \\
\hline Gostioničari & $\begin{array}{l}\text { Grünwald Beni, Hirschl Mavro, Komucki } \\
\text { losipa, Pichler Franjo, Šteiner Šandor }\end{array}$ & 5 & 3 & 8 \\
\hline $\begin{array}{l}\text { Klobučari - } \\
\text { kapari }\end{array}$ & $\begin{array}{l}\text { Ferenc Franjo, Lihman Blaž, Kolarić Franjo, } \\
\text { Kolarić Valent, Kolarić Vilko, Kulinc Ignac, } \\
\text { Zidarić Mirko }\end{array}$ & 7 & - & 7 \\
\hline
\end{tabular}


Rad Hrvat. akad. znan. i umjet. Razred za druš. znan. 55=545(2021) : 31-102

\begin{tabular}{|c|c|c|c|c|}
\hline Tiskari & Kostinčer Tito & 1 & - & 1 \\
\hline Kobasičari & Kunštek Josip & 1 & - & 1 \\
\hline Kolari & $\begin{array}{l}\text { Betlheim Ivan, Bukec Franjo, Mestrić Rudolf, } \\
\text { Solar Andro, Solar Ivan }\end{array}$ & 5 & 17 & 22 \\
\hline Kotlari & Strahinja Ivan & 1 & - & 1 \\
\hline Kovači & $\begin{array}{l}\text { Bocak Josip, Detelj Franjo, Karteš Josip, Kartis } \\
\text { Josip, Klamer Ivan, Pazić Adolf, Potočnjak } \\
\text { Imbro, Pročić Franjo, Radotović Lazo, Sokač } \\
\text { Franjo, Solar Josip, Turković Ferdo, Župić } \\
\text { Mavro }\end{array}$ & 13 & 57 & 70 \\
\hline Kožari & $\begin{array}{l}\text { Filipović Stanko, Filipović Stjepan, Vehovec } \\
\text { Lovro }\end{array}$ & 3 & - & 3 \\
\hline Krčmari & $\begin{array}{l}\text { Antolković Mio, Ban Mato, Betlheim Ivan, } \\
\text { Damović Josip, Dobranić Maria, Gjurin Tomo, } \\
\text { Glogovski Gabro, Graf Lavoslav, Grdelac } \\
\text { Marko, Garničec Petar, Han Aron, Hirschler } \\
\text { Josip, Hocheger Josip, Horvat Andro, Janeš } \\
\text { Stjepan, Jambrek Franjo, Kamasić Verona, } \\
\text { Kamenar Ignac, Kanik Ivan, Kovač Ana, } \\
\text { Kovač Marko, Košćak Gjuro, Lukinec Mirko, } \\
\text { Mager Šimun, Manzer Josip, Milek Bara, } \\
\text { Nebojčić Imbro, Nespor Antun, Ostrovski } \\
\text { Jakov, Petričić Benko, Pevalek Josip, Pevalek } \\
\text { Vjekoslav, Rogina Ivan, Senjan Mio, Seiwert } \\
\text { Adolf, Schifkorn Ivan, Španić Rok, Solar Josip, } \\
\text { Ugarković Maria, Vartić Vatroslav, Vidoš Mato, } \\
\text { Vrbnjak Štefan, Weinberger Gjuro, Zrinšćak } \\
\text { Ignac }\end{array}$ & 44 & 60 & 104 \\
\hline Krojači & $\begin{array}{l}\text { Bek Ignac, Beranek Petar, Biba Ignac, Cesarec } \\
\text { Jakob, Ferček Janko, Fürst Fany, Gruntner } \\
\text { Ferdo, } \\
\text { Heinrich Netti, Hochegger Josip, Klluger Izrael, } \\
\text { Kanašić Luka, Kosina Andro, Križan Mato, Lauš } \\
\text { Mavro, Leipnik Albert, Loborec Gjuro, Loborec } \\
\text { Josip, Lovreković Pavao, Lukman Martin, } \\
\text { Mešnjak Stjepan, Neubert Ivan, Pergarić Franjo, } \\
\text { Podneski Ivan, Prepelec Mato, Rižner Valent, } \\
\text { Šmauc Jakob, Šavor Stjepan, Weiss Mavro }\end{array}$ & 28 & 4 & 32 \\
\hline Krznari & $\begin{array}{l}\text { Celak Mato, Kopija Antun, Korošec Adam, } \\
\text { Križan Ivan, Tkalčec Ivan, Zidarić Andro }\end{array}$ & 6 & - & 6 \\
\hline $\begin{array}{l}\text { Limari - } \\
\text { špengleri }\end{array}$ & Samek Makso & 1 & - & 1 \\
\hline Ljekarnici & Smekal D., Zeiga F. & 2 & - & 2 \\
\hline
\end{tabular}




\begin{tabular}{|c|c|c|c|c|}
\hline Lončari & $\begin{array}{l}\text { Belaić Mio, Dobrovec Josip, Hardi Ivan, Haroš } \\
\text { Bara, Kršan Stjepan, Pišćak Mirko, Posavec } \\
\text { Lovro, Šimek Ivan, Viker Rudolf }\end{array}$ & 9 & 5 & 14 \\
\hline $\begin{array}{l}\text { Bojadisar } \\
\text { tkanina }\end{array}$ & Gross Šandor & 1 & - & 1 \\
\hline $\begin{array}{l}\text { Medičari i } \\
\text { voštari }\end{array}$ & Hadjak Josip, Kovačić Jula, Sulimanović Josip & 3 & - & 3 \\
\hline Mesari & $\begin{array}{l}\text { Fuchs Valent, Glass Franjo, Grasek Antun, } \\
\text { Grubešić Josip, Hagen Josip, Hirschl Ignac, } \\
\text { Hirschler Josip, Ivančić Gjuro, Jaklin Antun, } \\
\text { Kovačić Ivan, Kristofić Vinko, Mališa Antun, } \\
\text { Neufeld Roza, Petričić Petar, Pevalek Josip, } \\
\text { Podunajec Tomo, Siletić Gjuro, Šimunković } \\
\text { Josip, Singer Leopold }\end{array}$ & 19 & 13 & 32 \\
\hline Mlinari & $\begin{array}{l}\text { Butina Tomo, Dlaka Vinko u Bregima, Križek } \\
\text { Martin, Kvakarić S., Pravdić Andro, Semeraj } \\
\text { Gjuro, Šparholc Lavoslav, Vaš Stjepan }\end{array}$ & 8 & 102 & 110 \\
\hline Nožari & Kolar Dragutin & 1 & - & 1 \\
\hline Opančari & $\begin{array}{l}\text { Hakman Valent, Ivanek Mirko, Ivković Stjepan, } \\
\text { Košak Franjo, Kovačević Janko, Kovačević } \\
\text { Kristina, Kovačević Janko, Miklučić Antun, } \\
\text { Sakulja Gjuro, Satvari Cila, Šćetinec Ljudevit, } \\
\text { Šimunović Andro, Uzvrc Dmitar, Vrban Imbro }\end{array}$ & 14 & 6 & 20 \\
\hline $\begin{array}{l}\text { Ciglana - } \\
\text { opekarna }\end{array}$ & Općina Koprivnica & 1 & - & 1 \\
\hline Pekari & $\begin{array}{l}\text { Durlan Lacko, Mautner Vilim, Šagaršeg Gjuro, } \\
\text { Toljan Milan, Urek Ivan }\end{array}$ & 5 & 7 & 12 \\
\hline Poduzetnici & Sodić Martin & 1 & - & 1 \\
\hline Postolari & $\begin{array}{l}\text { Barković Franjo, Blagojna Martin, Furić } \\
\text { Leopold, Habada Franjo, Horvat Kata, Hulina } \\
\text { Mirko, Jambrec Grga, Jurić Mato, Klein Ferdo, } \\
\text { Koćurko Franjo, Konjiček Šimun, Kopričanec } \\
\text { Ferdo u Bregima, Kudelić Stjepan, Kvakarić } \\
\text { Tomo, Lengyel Ludvig, Lončarić Josip, Malec } \\
\text { Ivan, Malec Janko, Marenić Aleksa, Martinušić } \\
\text { Ignac, Martinušić Martin, Orban Franjo, } \\
\text { Spreiner Julio, Spielberger Josip, Steiner Filip, } \\
\text { Tončić Ivan, Varović Jakob, Viker Vjekoslav, } \\
\text { Vragović Ivan, Vukić Tomo, Zgorelec Ivan, } \\
\text { Zidarić Josip, Zrnić Pavao }\end{array}$ & 33 & 28 & 61 \\
\hline Sapunari & Sepić Franjo & 1 & 1 & 2 \\
\hline
\end{tabular}




\begin{tabular}{|c|c|c|c|c|}
\hline $\begin{array}{l}\text { Sedlari i } \\
\text { remenari }\end{array}$ & $\begin{array}{l}\text { Dretar Petar, Grbčić Mio, Ivanković Antun, } \\
\text { Kristian Josip ml., Kristian Josip st., Miksovski } \\
\text { Josip }\end{array}$ & 6 & - & 6 \\
\hline Slikari soba & Anzel Lovro, Regina Josip & 2 & - & 2 \\
\hline Sodari vode & Löfler Natan & 1 & - & 1 \\
\hline Stolari & $\begin{array}{l}\text { Cmrk Tomo u Bregima, Jakupek Josip, Kaučić } \\
\text { Ivan, Kesternak Josip, Kolar Vid, Koščal Josip, } \\
\text { Kosinja Rudolf, Kovačević Gjuro, Levi Ssmuel, } \\
\text { Lipovec Franjo, Lovreković Antun, Peras Ignac } \\
\text { u Bregima, Postružin Ivan, Sabadi Ferdo, Sefček } \\
\text { Vaclav, Vettinger Josip, Žumbor Antun }\end{array}$ & 18 & 12 & 29 \\
\hline Svratištari & Schlossberger Makso & 1 & - & 1 \\
\hline Tesari & Bedenik Martin, Vajda Jakob & 2 & 2 & 4 \\
\hline Tkalci & $\begin{array}{l}\text { Bahunjak Stjepan, Brauneger Franjo, Capari } \\
\text { Gjuro, Filipčić Marko, Gašparić Leopold, } \\
\text { Gudić Rok, Jakupić Gjuro u Bregima, Jara } \\
\text { Franjo, Knapić Pavao, Kropaj Josip, Lesobar } \\
\text { Stjepan, Majcen Iva u Bregima. Mikulin Joso, } \\
\text { Purgarić Ana, Sablić Ivan u Bregima, Salaj Mio } \\
\text { u Bregima, Vandekar Antun u Bregima, Žižko } \\
\text { Konstantin }\end{array}$ & 18 & 2 & 20 \\
\hline Urari & Galduner Otto, Leitmeier Teodor & 2 & - & 2 \\
\hline Užari & $\begin{array}{l}\text { Jakčin Franjo, Grubešić Franjo, Kompari } \\
\text { Stjepan, Mihalić Antun, Šćetinec Katarina }\end{array}$ & 5 & - & 5 \\
\hline Zidari & $\begin{array}{l}\text { Florjan Ivan, Kokolić Josip, Kralj Blaž, Reš } \\
\text { Josip, Reš Vinko, Zidarić Josip }\end{array}$ & 6 & 2 & 8 \\
\hline Ukupno & & 324 & 332 & 656 \\
\hline
\end{tabular}

* G. JUSTUS, L. STROHMAYER, Adresar obrtnog i poslovnog svieta u Hrvatskoj g. 1890, Zagreb, 1891, str. 49-210. Podcrtana su ženska imena.

Tablica 4 ukazuje na struke obrtnika u gradu i kotaru te broj obrtnika u tim strukama. Poimence su navedeni imenom i prezimenom obrtnici i obrtnice grada Koprivnice, a zatim je u stupcu iza broja obrtnika u gradu naveden broj obrtnika iste struke $u$ kotaru na osnovi tablice 5, čime je omogućena kvantifikacija obrtnika u gradu i izvan njega na području kotara. Na osnovi iskazanog zaključuje se da je broj obrtnika u kotaru bez grada bio veći od broja obrtnika u gradu, što ukazuje na jak gospodarski potencijal sela, odnosno agrarni karakter čitavog kraja kada urbanizacija i industrijalizacija još nisu uzele većeg maha. 
Svi su obrti individualizirani, a samo je koprivnička ciglana u vlasništvu i pod upravom grada, pa to obilježava moderizaciju i gradnju kuća od cigle; kuće od drva prestaju se graditi, što je i posljedica velike sječe šuma.

U tablici su podcrtana imena žena obrtnica, ali - s obzirom na to da su kod nekih prezimena umjesto punog imena navedeni samo inicijali - moramo pretpostaviti da se i tu prikriva možda neka obrtnica. Ta primjedba vrijedi i za sve druge tablice $\mathrm{u}$ ovom radu.

U gradu Koprivnici radilo je 20 obrtnica, i to: Maria Jagodić imala je frizersku radnju, a Josipa Toplak čizmarsku radnju, krčmarice su bile Maria Dobranić, Verolna Komasić, Ana Kovač, Bara Milek i Maria Ugarković, krojačice su bile Fany Fürst i Natti Heinrich, a njihova imena ukazuju na to da su promicale modu srednje, a možda i zapadne Europe. Lončarstvom se bavila Bara Haroš. Medičarka i izrađivačica svijeća bila je Jula Kovačić, kao mesarica je radila Roza Neufeld; opančarke su bile Kristina Kovačević i Cila Satvari, postolarsku radionicu držala je Kata Horvat, a tkanjem se bavila Iva Majcen iz Koprivničkih Brega, koji su se smatrali sastavnim dijelom grada. Ana Purgarić i Katarina Šćetinec imale su užariju.

U tablicama su navedene samo gospodarski aktivne osobe, s time da je vjerojatno svaki obrtnik imao i obitelj, pa je od obrta u gradu i u kotaru živjelo više od tisuću osoba. U svakom slučaju, 324 obrtnika u gradu i 332 u kotaru, to jest 656 obrtnika i obrtnica velik je broj, a njihova raspodjela u 32 skupine zanimanja pokazuje bolju razgranatost nego što je bila prije kod cehova i kućnih zadruga, koje su već gotovo posve nestale na tom području.

Svakako je zanimljivo da je u kotaru bilo čak i malo više obrtnika negoli u gradu, što je posljedica nastojanja da svako selo ima krčmu i bačvara te svojeg kolara, stolara i kovača jer su kola tada bila najvažnije prijevozno sredstvo za ljude i robu s polja i iz šume. Stoga taj podatak ne iznenađuje, premda razloge možemo tražiti i u agrarnoj prenaseljenosti, uslijed čega se koristila svaka mogućnost zarade. Tako su obrtnici na selu imali većinom dva zanimanja, obrtničko i poljoprivredno, a spretan seljak popravljao je i izrađivao sve što je znao i mogao, pa su mnogi radili kao sezonski radnici u izvlačenju drva iz šuma zimi ili su se bavili rudarenjem u ono nekoliko lignitskih ugljenika za kojima je potreba željeznica i radionica bila velika; zbog nedostatka zrelih šuma, ugljenom su se namirivali i krajišnici u imovnim općinama.

Može se pretpostaviti da su obrtnici u Koprivnici raspolagali većim znanjem i da su imali bolju opremu nego obrtnici na selu, pa i da su došli u grad iz okolice radi lakšeg školovanja djece i većeg broja korisnika...

U Koprivnici su radila 44 krčmara, pet gostioničara i jedan svratištar, čime su bile zadovoljene sve potrebe građana, ali i gostiju koji su dolazili u grad i često nastavljali put do krajnjeg odredišta. To je vrijeme kada se počinje njegovati i noćni 
život u krčmama oko željezničke stanice. No iznenađuje da je u kotaru radilo 60 krčmi i tri gostioničara, pa su očito gostionice bile mjesta sastanaka mještana gdje su se raspravljala važna pitanja, ali i gdje su trgovački putnici i prolaznici obavljali svoje poslove i dobivali potrebne informacije. Detaljnija analiza pokazuje da su krčmari često bili Židovi koji su svoje poslovanje vezali i uz trgovinu mješovitom robom ili sitničarenjem. I u gradu Koprivnici krčme su imale važnu društvenu ulogu, pa su upravo one među prvima regulirale svoje odnose posebnim pravilima. U krčmama se točilo i vino, ali i - s obzirom na vojničku tradiciju grada - i pivo, pa iznenađuje da Koprivnica nije imala u tom vremenu posebnu vinariju ili pivovaru. Uostalom, s Križevcima, gdje je Katz vario pivo, postojala je dobra željeznička povezanost. Mnogi krčmari i gostioničari bili su i gradski zastupnici. Tako posjedujemo dokument kojim poljodjelac, mesarski i krčmarski obrtnik i gradski zastupnik iz Koprivničkih Brega Tomo Podunajec podnosi corpus separatum protiv zaključka gradskog zastupstva od 15. ožujka 1893. žaleći se što je sječa gradske šume Lešce pokraj Brega posve uništila cestu izvozom drva, pa moli da se cesta umjesto s 200 hrpa pruća obloži s 300 hrpa kako bi se njome mogao lakše odvijati promet, a traži se i direktna cesta iz Sigeca do Brega. ${ }^{15}$

Struktura obrtnika ukazuje na to da je odjevna i obućarska proizvodnja još uvijek bila u rukama domaćih obrtnika koji su svoje proizvode prodavali i na sajmovima. Nema još ni Tivara ni Bate, pa se domaći tkalci bave izradom tkanina na tkalačkim strojevima, a isto to možemo pretpostaviti i kod izrade obuće raznih vrsta. U Koprivnici 36 čizmara svjedoči o tome da su se, zbog blatnjavih putova i poljoprivrednog rada, mnogo nosile čizme, a u Koprivnici nije još bilo nijedne asfaltirane ulice. Možemo zaključiti da je životom dominirala samodostatnost, ali i skromnost osobnih potreba. Mnogi su se nastojali opskrbiti kod domaćih obrtnika koji su bili i ugledne osobe u gradu i članovi mnogih odbora i društava. Zidara je bilo u gradu svega šest, a među njima i Josip i Vinko Reš, koji su gradili u Koprivnici gotovo pola stoljeća. Grad Koprivnica, zbog prometa na graničnom prijelazu, ušao je u razdoblje velikog poleta pridolaskom Židova koji su se bavili trgovinom, pa su se počele graditi prve privatne jednokatnice u historicističko-secesijskom stilu. ${ }^{16}$ Obrtnici koji su kao naučnici proputovali Ugarskom i Austrijom stekli su tamo ne samo najnovija znanja o svojem poslu već su stekli i naviku jačanja društvene povezanosti, što se osjetilo u životu grada.

15 Hrvatski državni arhiv, Upravni odjel Zemaljske vlade, kut. 928/ br. 1915. Podunajec je bio gradski zastupnik u vrijeme povjerenika Kolomana pl. Mattaschicha. U tom vremenu zastupnici su bili Arnold Betlheim, David Deutsch, Šandor Gross, Jacques Hirsler, Andro Horvat, Martin Krapec, Franjo Kušević, Benko Petričić, Martin Puhalo, Tomo Podunajec, Josip Reš, Josip Roga, Gjuro Vaić, Mato Vidoša, Mirko Kvakarić i dr. Matija Pavelić, Ivan Rogina i Ljubomir Živković.

16 Draženka ERNEČIĆ, Vrijeme velikog poleta. Historicističko-secesijska izgradnja grada, u: Koprivnica. Izabrane teme, II. izdanje, Koprivnica, 1997., 91-101. 
Analiza Adresara navodi nas na zaključak da se sve potrebno za tadašnji način života moglo nabaviti u gradu Koprivnici, ali da su neke struke vezane uz rad na zemlji bile jače zastupljene u malim mjestima na području kotara nego u gradu (tablica 4 i 5). U grad se dolazilo uglavnom radi sajmova, koji su bili tjedni, mjesečni i godišnji. Na njima su se, na Sajmišnom trgu, gdje je bila i vaga, prodavali stoka i žito, ali se počela kupovati i industrijska roba iz razvijenijih dijelova Monarhije. U to su vrijeme spretni židovski trgovci već preuzeli najbolje lokacije za trgovinu u gradu, iskoristivši rušenje starih gradskih bedema, te su tu sagradili i nove dobro građene zgrade, a domaći obrtnici i sitniji trgovci povukli su se na drugu liniju, na periferiju grada. Njihovi su lokali bili manji i sačuvali su nešto od cehovske tradicije, sudeći po izloženoj robi i posebnom mirisu male radnje, ali i susretljivosti obrtnika da raspravlja o lokalnim događajima. U obrtnim radnjama često je radila čitava obitelj zajedno s kalfama i šegrtima, koji su bili obavezni polaziti šegrtsku školu. Radnja je obično bila uz kuću, gdje je domaćica vezala jedan i drugi dio svojim zalaganjem i radom. Novo gradsko središte nastoji poništiti sjećanje na vrijeme kada je grad imao i vojnu funkciju, a formiranje gradskog perivoja na račun prodaje šuma u blizini grada znatno mijenja njegov izgled. Dio tvrđave ostao je samo u tragovima u tzv. Varoškoj grabi, gdje se danas održava barokna tradicija posvećena starim obrtima.

Što se događalo poslije 1891. godine s obrtnicima, možemo naslutiti iz Spomenice Saveza hrvatskih obrtnika 1907. - 1935. U njoj je 1904. u gradu Koprivnici iskazano 289 obrtnika, ali su to bili samo obrtnici katoličke vjere udruženi u Savez. ${ }^{17}$ U svakom slučaju, udruživanje postaje važna karika društvenog života grada, ali ta podjela nije uvijek bila jako sretna. Društva su bila strukovne, vjerske i glazbene prirode i obično su bila čvrsta poveznica među članovima.

Po prezimenima možemo ipak zaključiti da je u Koprivnici bilo mnogo domaćih ljudi obrtnika koji su počeli poučavali buduće obrtnike kako bi položili stručne majstorske ispite pred Obrtnim zborom vezanim uz rad Trgovačkoobrtničke komore u Zagrebu, odakle su primali upute i savjete. Oko 1884. u Koprivnici je počela raditi šegrtska škola, te više nije bilo potrebno, kao u doba cehova, odlaziti na usavršavanje u druge dijelove Monarhije jer je starija generacija obrtnika znala prenositi svoja znanja mladima. ${ }^{18}$ Zanimljivo je da među domaćim prezimenima obrtnika ima vrlo malo onih koji su posegnuli za podizanjem tvornica, ali njihove potomke nalazimo i danas u Koprivnici kao stanovnike grada koji rade razne poslove.

17 Spomenica Saveza hrvatskih obrtnika 1907.-1933, Zagreb, 1934., str. 33.

18 Ružica BRAČKO-MEDVARIĆ, Mira KOLAR-DIMITRIJEVIĆ, Šegrtska škola u Koprivnici od 1886. do 1900 godine, Podrauski zbornik, 42, Koprivnica, 2017., str. 101-122. 


\section{Obrtnici u Koprivničkom kotaru bez grada Koprivnice 1890.}

Poimenični navod obrtnika u Koprivničkom kotaru ukazuje na velik broj obrtnika i obrtnica. To pokazuje na zatvorenost seoskih društava, koja imaju gotovo sve što im je potrebno za život i rad u svojem selu.

Kao što je gotovo svako selo dobilo svojeg trgovca, tako je sve do 1918. gotovo svako selo imalo i krčmu. Krčme su bile mjesta razmjene lokalnih vijesti, tamo se i slavilo i tugovalo, ali i dogovaralo u slučaju nevolja. Iako je za bana Khuen-Héderváryja uvođenjem visokog cenzusa smanjen broj birača, zanimanje za politiku uslijed nenarodne politike povećalo se, a i pojava sve većeg broja stranaka koje agitiraju uoči izbora, kada su i politički skupovi bili dozvoljeni, uvlači narod u politiku.

Loše i neuređene, a i malobrojne ceste ograničavale su zimi i tijekom proljetnih kiša kretanje stanovništva, ugrožavajući i rad obrtnika. Ceste su se dijelile na državne, županijske, kotarske, mjesne i seoske putove, a prohodne cijelu godinu bile su samo one ceste koje su se posipale kamenom tucanikom iz Moslavine ili iz šljunčare koja je otvorena kod Drnja prilikom gradnje željezničke pruge.

Tablica 5. Popis obrtnika u Koprivničkom kotaru bez grada Koprivnice, 1890. godine *

\begin{tabular}{|c|c|c|c|}
\hline Vrsta obrta & Mjesto obrtovanja & Poštanski ured & Prezime i ime obrtnika \\
\hline \multirow[t]{3}{*}{ Bačvari } & Gola & Gola & Kaučić Marko, Mörtel Ivan \\
\hline & Hlebine & Drnje & Posavec Gjuro \\
\hline & Novigrad & Novigrad & Ivanušec Tomo \\
\hline Brijači & Novigrad & Novigrad & Koel Gjuro \\
\hline Ciglari & Novigrad & Novigrad & Muženić Franjo, Rešen Petar \\
\hline Čizmari & Peteranec & Drnje & $\begin{array}{l}\text { Bugar Gjuro, Kacer Ivan, Znidarić } \\
\text { Blaž ml., Zidarić Blaž st. }\end{array}$ \\
\hline \multirow[t]{3}{*}{ Gostioničari } & Novigrad & Novigrad & Pevalek Franjo \\
\hline & Peteranec & Drnje & Vaić Mio \\
\hline & Sokolovac & Sokolovac & Toth Gašpar \\
\hline \multirow[t]{4}{*}{ Kolari } & Đelekovec & Drnje & $\begin{array}{l}\text { Madjar Mio, Željezak Blaž, } \\
\text { Željezak Štefo }\end{array}$ \\
\hline & Hlebine & Drnje & Janković Martin \\
\hline & Novi grad & Novigrad & $\begin{array}{l}\text { Imbri Gjuro, Ivanušec Ivo, Lovrićek } \\
\text { Bolto, Posavac Šimunić Ana, } \\
\text { Posavec Franjo }\end{array}$ \\
\hline & Peteranec & Drnje & $\begin{array}{l}\text { Belčić Martin, Gudek Tomo, Ornik } \\
\text { Franjo }\end{array}$ \\
\hline
\end{tabular}


Rad Hrvat. akad. znan. i umjet. Razred za druš. znan. 55=545(2021) : 31-102

Mira Kolar-Dimitrijević: Popis obrtnika na području današnje Koprivničko-križevačke županije 1890. godine

\begin{tabular}{|c|c|c|c|}
\hline & Sigetec & Koprivnica & Juriša Ivan, Šemper Pavo \\
\hline & Torčec-Gjelekovec & Drnje & $\begin{array}{l}\text { Kosnica Imbro, Kovačević Martin, } \\
\text { Sataić Joso }\end{array}$ \\
\hline \multirow[t]{16}{*}{ Kovači } & Badtinovec & Sokolovac & Lovrenčić Andro \\
\hline & Botovo & Drnje & Dombaj Mato \\
\hline & Drnje & Drnje & Sočev N., Jelenko N., \\
\hline & Gjelekovec & Drnje & $\begin{array}{l}\text { Omrok Tomo, Gažić Josip, Vuljak } \\
\text { Imbro, Vuljak Tomo }\end{array}$ \\
\hline & Gola & Gola & Butor Franjo, Kendjelić Ivo \\
\hline & Gotalovo & Gola & Gjörgy Kiš, Premec Tomo \\
\hline & Hampovica & Novigrad & $\begin{array}{l}\text { Šabarić Dragutin, Šabarić Nikola, } \\
\text { Vicenski Ivo }\end{array}$ \\
\hline & Hlebine & Drnje & $\begin{array}{l}\text { Družinić Josip, Filiipović Gjuro, } \\
\text { Gabaj Mato, Generalić Franjo, } \\
\text { Generalić Pavao, Imbriovčan Mato, } \\
\text { Jankač Štef }\end{array}$ \\
\hline & Kunovec & Rasinja & $\begin{array}{l}\text { Jambrešić Gjuro, Sučić Ivan, } \\
\text { Vinković G. }\end{array}$ \\
\hline & Miholjanec & Novigrad & Dikon Gjuro, Kuštrak Jakob \\
\hline & Mučna velika & Sokolovec & Gjurgjek N. \\
\hline & Novigrad & Novigrad & $\begin{array}{l}\text { Adaković Štefo, Fačeng Imbro, } \\
\text { Gabo Josip, Helinger Dora, Maljak } \\
\text { Franjo, Mićurin Mato, Mužinić } \\
\text { Ivo, Peroš Franjo, Peroš Ivo, Peroš } \\
\text { Martin, Šoštarić Jozo }\end{array}$ \\
\hline & Peteranec & Drnje & $\begin{array}{l}\text { Benotić Franjo, Blažek Tomo, } \\
\text { Bukek Jakob, Gjurinec Vid, Horvat } \\
\text { Franjo, Lukač Tomo, Pavuško } \\
\text { Bolto, Samodji Franjo, Maurer Ante, } \\
\text { Nemet Janoš, Vereš Stjepan }\end{array}$ \\
\hline & Sigetec & Drnje & $\begin{array}{l}\text { Berita Franjo, Eršeg Andro, } \\
\text { Kanižanec Mato, Klobučarić Blaž, } \\
\text { Vlahović Štefo }\end{array}$ \\
\hline & Sokolovac & Sokolovac & Balaš Štefan \\
\hline & Torčec & Drnje & Šatarić Ivo \\
\hline \multirow[t]{2}{*}{ Krčmari } & Batinovec & Sokolovac & $\begin{array}{l}\text { Gvozdanović Stevo, Ivanić Ivo, } \\
\text { Toljan Maria, Weiss Aleksandar }\end{array}$ \\
\hline & Botovo & Drnje & $\begin{array}{l}\text { Kratohvil Ivan, Lang Viktor, Lakman } \\
\text { Antun }\end{array}$ \\
\hline
\end{tabular}


Rad Hrvat. akad. znan. i umjet. Razred za druš. znan. 55=545(2021) : 31-102 Mira Kolar-Dimitrijević: Popis obrtnika na području današnje Koprivničko-križevačke županije 1890. godine

\begin{tabular}{|c|c|c|c|}
\hline & Drnje & Drnje & $\begin{array}{l}\text { Hveh Josip, Hofman Jakob, Spitzer } \\
\text { Filip, Štimac Josip, Vaić Mio, Volak } \\
\text { Julius, Žagar Pavao }\end{array}$ \\
\hline & Gjelekovec & Drnje & Horvat Luka \\
\hline & Gola & Gola & Amzelberg David, Weiss Josiip \\
\hline & Gotalovo & Gola & Grünbaum Vilim \\
\hline & Grubičane veliko & Sokolovac & $\begin{array}{l}\text { Fajtović Stevo, Jakčin Jakob, } \\
\text { Lazarević Simo, Vrabčević Todor }\end{array}$ \\
\hline & Hampovica & Novigrad & Hrga Rajmund \\
\hline & Hlebine & Drnje & $\begin{array}{l}\text { Culek N., Čarbo Bolto, Goldberger } \\
\text { Josip, Mesaroš Josip, Schwarz } \\
\text { Antun }\end{array}$ \\
\hline & $\begin{array}{l}\text { Imbrijovec - } \\
\text { Gjelekovec }\end{array}$ & $\begin{array}{l}\text { Legrad - } \\
\text { Ugarska }\end{array}$ & Fischer David \\
\hline & Ivanec - Gjelekovec & Koprivnica & Matica Mato, Rosenberg Mavro \\
\hline & Jagnjedovac & Koprivnica & Löwy Johana, Turk Ivan \\
\hline & Javorovac & Novigrad & Slandri Mara \\
\hline & Kunovec & Rasinja & Kreutzer Samuel \\
\hline & Ladislav - Laislav & Novigrad & Kalivoda Marija, Weiss Jakob \\
\hline & Lepavina & Sokolovac & Samostan o. franjevaca \\
\hline & Mučna mala & Sokolovac & Janić Rade \\
\hline & Mučna velika & Sokolovac & 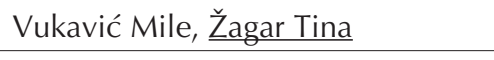 \\
\hline & Novigrad & Novigrad & $\begin{array}{l}\text { Amselberger Albert, Deutsch } \\
\text { Moses, Ivančić Gjuro, Matunci Mio }\end{array}$ \\
\hline & Peteranec & Drnje & $\begin{array}{l}\text { Eisenstedter Filip, Hofman Jakob, } \\
\text { Machan Agneza, Zierer Samuel }\end{array}$ \\
\hline & Plavšinac & Novigrad & $\begin{array}{l}\text { Ljubešić Sofija, Matunci Mio, } \\
\text { Mihalfi Josip }\end{array}$ \\
\hline & Ruševac & Sokolovac & $\begin{array}{l}\text { Crnčić Martin, Horvat Imbro,_ } \\
\text { Horvat Manda }\end{array}$ \\
\hline & Sigetec - Peteranec & Drnje & Grabarić Valent \\
\hline & Sriem & Sokolovac & $\begin{array}{l}\text { Bačlin Mato, Dolovčak Mato, Jamić } \\
\text { Rade }\end{array}$ \\
\hline & $\begin{array}{l}\text { Torčec - } \\
\text { Gjelekovec }\end{array}$ & Drnje & Ivko Adolf \\
\hline \multirow[t]{2}{*}{ Krojači } & Novigrad & Novigrad & $\begin{array}{l}\text { Pezak Franjo, Turinek Antun, Ubitil } \\
\text { Vencl }\end{array}$ \\
\hline & Sokolovac & Sokolovac & Fišer Simon \\
\hline
\end{tabular}


Rad Hrvat. akad. znan. i umjet. Razred za druš. znan. 55=545(2021) : 31-102

Mira Kolar-Dimitrijević: Popis obrtnika na području današnje Koprivničko-križevačke županije 1890. godine

\begin{tabular}{|c|c|c|c|}
\hline \multirow[t]{3}{*}{ Lončari } & Miholjanec & Novigrad & Kos Martin, Vicenski Mato \\
\hline & Novigrad & Novigrad & Petrović Ivan, Sigmund Mijo \\
\hline & Sokolovac & Sokolovac & Jaklin Martin \\
\hline \multirow[t]{8}{*}{ Mesari } & Gjelekovec & Drnje & Šalamun Martin \\
\hline & Gola & Gola & Husić Pavao \\
\hline & Grabičani Veliki & Sokolovac & Bodin Todor, Marčinko Mirko \\
\hline & Hlebine & Drnje & $\begin{array}{l}\text { Goldberger Josip, Mesarić Josip, } \\
\text { Schwart Anton }\end{array}$ \\
\hline & Jagnjedovec & Koprivnica & Weiss Samuel \\
\hline & Kunovec & Rasinja & Kreutzer Samuel \\
\hline & Novigrad & Novigrad & $\begin{array}{l}\text { Amelberg Albert, Pevalek Franjo, } \\
\text { Bogari Ignac }\end{array}$ \\
\hline & Sokolovac & Sokolovac & Sonenschein Adolf \\
\hline \multirow[t]{8}{*}{ Mlinari } & Drnje & Drnje & $\begin{array}{l}\text { Benotić Marija i Sablić, Dambaj } \\
\text { Mijo, Kičinbači N., Kolarić Mato, } \\
\text { Lendvaj i Peršić, Pavlović Bolto, } \\
\text { Petrović Štefo, Stancar Gjuro, } \\
\text { Sukman Antun, Šonac Mato, Tabuš } \\
\text { i drug, Varavić Ana, Valaj Ivan. }\end{array}$ \\
\hline & Gjelekovec & Drnje & $\begin{array}{l}\text { Androlić Valent, Dolenec Pavao, } \\
\text { Harmai Gjuro, Salamon Franjo, } \\
\text { Samošćanec Stjepan }\end{array}$ \\
\hline & Gola & Gola & $\begin{array}{l}\text { Balaš Josip, Kušić Mijo, Lukačić } \\
\text { Gjuro, Nemec Martin, Petanović } \\
\text { Josip, Petljanović Joso, Palačnjak } \\
\text { Franjo }\end{array}$ \\
\hline & Gotalovo & Gola & $\begin{array}{l}\text { Balog Josip, Curi Pavao, Imbro } \\
\text { Andraš, Kolar Franjo, Kolar Janči, } \\
\text { Marget Josip, Rozman Tomo, Sokač } \\
\text { Janoš }\end{array}$ \\
\hline & Grabičane Velike & Sokolovac & $\begin{array}{l}\text { Bodin Todor, Klamer Franjo, } \\
\text { Marčinko Mio, Paler Josip, Turk } \\
\text { Josip }\end{array}$ \\
\hline & Hampovica & Novigrad & $\begin{array}{l}\text { Borko Ivo, Gluhak Valent, Pandur } \\
\text { Štefo, Šabarić Blaž, Štefec Ivo, } \\
\text { Štamec Bolto }\end{array}$ \\
\hline & Hlebine & Drnje & $\begin{array}{l}\text { Bok Gjuro, Jerebić Jakob, Kokar } \\
\text { Josip, Magdić Mirko, Miholek Mio, } \\
\text { Pakošin Jakob, Pokec Ferko }\end{array}$ \\
\hline & Ivanec Gjelekovec & Koprivnica & Muger Gjuro \\
\hline
\end{tabular}


Rad Hrvat. akad. znan. i umjet. Razred za druš. znan. 55=545(2021) : 31-102

Mira Kolar-Dimitrijević: Popis obrtnika na području današnje Koprivničko-križevačke županije 1890. godine

\begin{tabular}{|c|c|c|c|}
\hline & Javorovac & Novigrad & $\begin{array}{l}\text { Halapa Mato, Rozmarić Andra, } \\
\text { Siandri Mara, Štefan Petar }\end{array}$ \\
\hline & Kunovec & Rasinja & Edišar Jula, Podmajec Gjuro \\
\hline & Lepavina & Sokolovac & Franjevački samostan \\
\hline & Miholjanec & Novigrad & $\begin{array}{l}\text { Antolaš Petar, Kos Stevo, Ledeš } \\
\text { Gjuro, Martinić Stevo, Mihoković } \\
\text { Valent, Patačko Petar, Suntić Karlo, } \\
\text { Weiss Adolf }\end{array}$ \\
\hline & Mučna Mala & Sokolovac & $\begin{array}{l}\text { Fras-Magar Martin, Hanžeković } \\
\text { Joso, Petanji Petar }\end{array}$ \\
\hline & Mučne Velika & Sokolovac & $\begin{array}{l}\text { Bakany Josip, Baranec Jakob, } \\
\text { Baranić Ferdo, Baranić Franjo, } \\
\text { Koprivec Stjepan, Trumbetaš Pavao }\end{array}$ \\
\hline & Novigrad & Novigrad & $\begin{array}{l}\text { Karjačić Mio, Kuzman Franjo, } \\
\text { Molnar Gjuro, Pavelić Pavao, } \\
\text { Poligač Viktor, Puškarić Franjo, } \\
\text { Scandri Janko, Sebatian Alois }\end{array}$ \\
\hline & Rieka - Sokolovac & Koprivnica & $\begin{array}{l}\text { Benko Kalman, Grgelj Janoš, } \\
\text { Milivojević Gjuro, Vandjjja Gjuro }\end{array}$ \\
\hline & Ruševac & Sokolovac & $\begin{array}{l}\text { Bajžar Tomo, Crnčić Imbro, Horvat } \\
\text { Petar }\end{array}$ \\
\hline & Sigetec - Peteranec & Drnje & $\begin{array}{l}\text { Kolarić Andro, Korošec Mara, } \\
\text { Nenadan Tomo, Penač Blaž, Šianec } \\
\text { Jakob }\end{array}$ \\
\hline & Sokolovac & Sokolovac & Janković Stevo, Ostoić Mile \\
\hline & $\begin{array}{l}\text { Torčec - } \\
\text { Gjelekovec }\end{array}$ & Drnje & $\begin{array}{l}\text { Lakuš Ivo, Vukovec Karlo, Vukovec } \\
\text { Dragutin }\end{array}$ \\
\hline \multirow[t]{3}{*}{ Opančari } & Hampovica & Novigrad & Hunjet Gjuro, Sabarić Stefo \\
\hline & Mučna Mala & Sokolovac & Duda Franjo \\
\hline & Novigrad & Novigrad & $\begin{array}{l}\text { Forko Franjo, Mužinić Imbro, Rušak } \\
\text { Imbro }\end{array}$ \\
\hline \multirow[t]{4}{*}{ Pekari } & Drnje & Drnje & Janavić N. \\
\hline & Gola & Gola & Gorčanec Lovro \\
\hline & Novigrad & Novigrad & Plemenčić Ivan, Rozmarić Martin \\
\hline & Sokolovac & Sokolovac & $\frac{\text { Glücksfeld Tereza, Kastelić Ana, }}{\text { Mlinarić Mirko }}$ \\
\hline Postolari & Botovo & Drnje & Novak Mijo \\
\hline
\end{tabular}


Rad Hrvat. akad. znan. i umjet. Razred za druš. znan. 55=545(2021) : 31-102

\begin{tabular}{|c|c|c|c|}
\hline & Drnje & Drnje & $\begin{array}{l}\text { Ganzer Dragutin, Milek Gjuro, } \\
\text { Mužinić Gjuro, Sović Gjuro }\end{array}$ \\
\hline & Gjelekovec & Gjelekovec & $\begin{array}{l}\text { Golubić Niko, Kedmenec Andro, } \\
\text { Maltarić Andro, Šipek Viktor }\end{array}$ \\
\hline & Gola & Gola & Šandin Mijo, Vrban Blaž \\
\hline & Gotalovo & Gola & Cikač Blaž \\
\hline & Hampovica & Novigrad & Šabarić Štefo \\
\hline & Novigrad & Novigrad & $\begin{array}{l}\text { Bukovčan Martin, Ljubić Ivan, } \\
\text { Miler Ivan, Sabolić Bolto, Varjačić } \\
\text { Miko, Vedriš Franjo }\end{array}$ \\
\hline & Peteranec & Drnje & Jurašić Albert, Raufaj Filip \\
\hline & Plavšinac & Novigrad & Prebješić Alois \\
\hline & Rieka Gornja & Rieka Gornja & Kešek Aleks, Krofl Antun \\
\hline & Sigetec- Peteranec & Drnje & Vrban Franjo \\
\hline & Sokolovac & Sokolovac & $\begin{array}{l}\text { Hranić Mato, Kubić Adam, Pintarić } \\
\text { Ilija }\end{array}$ \\
\hline Sapunari & Sokolovac & Sokolovac & Glükstahl Vilim \\
\hline \multirow[t]{7}{*}{ Stolari } & Drnje & Drnje & Doktorić Martin, Mužinić Franjo \\
\hline & Hampovica & Novigrad & Lander Mio, Lomber Mio \\
\hline & Hlebine & Drnje & Hegedušić Ivo \\
\hline & Kunovec - Rasinja & Rasinja & Kralj Gjuro \\
\hline & Novigrad & Novigrad & Klanček Bara, udovca, Ligman Mio \\
\hline & Peteranec & Drnje & $\begin{array}{l}\text { Cesarec Gabriel, Kodmenec Ivo, } \\
\text { Kodmenec Ivan }\end{array}$ \\
\hline & Sigetec - Peteranec & Drnje & Barić Gjuro \\
\hline \multirow[t]{2}{*}{ Tesari } & Gola & Gola & Nemet Šandor \\
\hline & Sokolovac & Sokolovac & Kokolj Alois \\
\hline \multirow[t]{2}{*}{ Tkalci } & Gola & Gola & Graf Imbro \\
\hline & Sigetec - Peteranec & Drnje & Valent Tomo \\
\hline Tokari & Novigrad & Novigrad & Fačeng Gjuro \\
\hline Zidari & Drnje & Drnje & Augustinović Antun, Škripec N., \\
\hline Ukupno & & & 332 \\
\hline
\end{tabular}

* G. JUSTUS, L. STROHMAYER, Adresar obrtnog i poslovnog svieta u Hrvatskoj g. 1890, Zagreb, 1891., str. 49-211. 
Tablica 5 sadrži popis obrtnika u Koprivničkom kotaru bez grada. Kod svakog mjesta određene struke iskazuje se i pošta kojom su se obrtnici služili, jer je to bilo jedini način izvanseoske komunikacije. Vidimo da se koriste poštanske usluge u Drnju, Novigradu Podravskom, Rasinji, Goli i Reki, a ponekad i u drugim poštanskim uredima. Neki Đelekovčani služili su se poštom u Drnju, pa su u Adresaru tako i iskazani i uvršteni u našu tablicu 5, iako po političkoj razdiobi oni spadaju u to vrijeme pod Kotar Ludbreg, odnosno Varaždinsku županiju. Mnoga od tih mjesta danas imaju svoje monografije.

Gotovo su svi obrti u rukama privatnika, osim krčme i mlina u Lepavini, koje je držao franjevački samostan u Koprivnici.

Na području kotara radilo je 18 žena u obrtu, dakle gotovo isto toliko koliko i u gradu, ali su one radile samostalno samo kao krčmarice, mlinarice i pekarice, dok su u tri struke - kolarskoj, kovačkoj i stolarskoj - vjerojatno radile uz pomoć pomoćnika naslijedivši obrt poslije smrti supruga. U gradu su njihova zanima-

nja raznovrsnija, a vjerojatno su bile i samostalnije nego na selu. Žene obrtnice u kotaru bile su: Ana Šimunić, koja je imala kolarsku radnju; Dora Helinger, koja je držala kovačnicu, vjerojatno uz pomoć pomoćnika nakon smrti muža; najviše je bilo krčmarica, i to čak osam: Marija Toljan, Jelena Löwy, Mara Slandrik, Maria Kalivoda i Tina Žagar; četiri su bile mlinarice u Drnju na Dravi, i to Marija Benotić i Bara Varović, Mara Sandri, Jule Edišar i Mara Korošec; Tezera Glücksfeld i Ana Kastelić držale su pekarnicu; udovica Bara Klanček držala je stolariju i jedino je kod nje bilo naznačeno da je udovica.

\section{Obrtnici u gradu Križevcima.}

Taj stari grad, kao što to dokazuje kalnička utvrda te podjela na Donji i Gornji grad - vojnički i građanski - imao je spomena vrijednu ulogu u hrvatskoj povijesti i kulturi. U njemu je bilo i nekoliko plemićkih obitelji koje su znatno utjecale na povijest grada, ali su one većinom napustile vođenje posjeda. Političar i književnik Franjo Marković te osnivač Novinarskog društva Grlović, kao i mnogi drugi uglednici, potječu iz toga grada i njegove blizine, a njegova Gospodarska škola i planinarski dom bili su pioniri na tom području na našim prostorima podržavajući do danas i vizualno sjećanje na slavnu i značajnu prošlost. Upornost stanovnika toga grada u održavanju njihovih tradicija višestruko je dokazana. Međutim grad je upravo zbog politike počao gubiti svoju snagu i počeo je zaostajati kada je domaće nebogato plemstvo bilo udaljeno od vlasti. Prema Adresaru, Križevci po broju obrtnika zaostaju za gradom Koprivnicom, što znači da je politika utjecala na kupovnu moć stanovništva, što su prvi osjetili obrtnici koji su živjeli od rada svojih ruku. Srećom, u Križevce su mnogi pridošli 
iz Mađarske i Štajerske, te su u Križevcima počeli osnivati svoje radnje, pa i tvornice, a imali su posebnu ulogu u osnivanju štedionice. Upravnu funkciju gradu nadomješta gospodarstvo i osobito uslužne djelatnosti. Izuzetak čini obitelj Kiepach, koja se pojavljuje u Križevcima oko 1830. godine. Veleposjednik Josip Kiepach von Haselburg (1862. - 1940.), koji je oženjen barunicom Martom Locatelli od Scháönfelda, vodi veliko i uzorno gospodarstvo s četiri majura (Gregurovec, Dubovec, Među i Globočec), ciglanu u Gregurovcu te tri mlina i veliko lovište. ${ }^{19}$ Prema Adresaru, Kiepach je držao 1890. i krčmu u Križevcima.

Imena obrtnika u gradu navedena su prema Adresaru u tablici 6; kao i kod tablice 4, navodi se iza broja obrtnika u gradu i broj obrtnika u kotaru te suma obje skupine po strukama.

Tablica 6. Brojno stanje obrtnika u gradu Križevcima i usporedba s brojem obrtnika u kotaru 1890. godine.

\begin{tabular}{|c|c|c|c|c|}
\hline \multirow[t]{2}{*}{ Vrsta obrta } & \multirow[t]{2}{*}{ Ime i prezime obrtnika u gradu } & \multicolumn{3}{|c|}{ Broj obrtnika } \\
\hline & & U gradu & U kotaru & Ukupno \\
\hline Bačvari & $\begin{array}{l}\text { Berc Antun, Britvec Lujo, Dubravec Josip, } \\
\text { Dubravec Stjepan, Genc Petar, Ivanuša } \\
\text { Ivan, Kamenović Stjepan, Markulin Mijo, } \\
\text { Šaško Luka, Timber Imbro }\end{array}$ & 10 & 2 & 12 \\
\hline Bravari & $\begin{array}{l}\text { Danić Lujo, Danić Melkior, Ivančić Mirko, } \\
\text { Kovačić Dragutin, Kovačić Franjo, Slaviček } \\
\text { Mirko }\end{array}$ & 6 & 2 & 8 \\
\hline Brijači & $\begin{array}{l}\text { Grloci Dragutin, Grloci Vilim, Huber } \\
\text { Stjepan, Križe Dragutin, Švagalj Ante }\end{array}$ & 5 & - & 5 \\
\hline Ciglari & - & - & 4 & 4 \\
\hline Češljari & Zorić Josip & 1 & - & 1 \\
\hline Četkari & Černobeus Franjo & 1 & - & 1 \\
\hline Čizmari & $\begin{array}{l}\text { Blažinčić Stevo, Budalec Gabro, Car Josip, } \\
\text { Detbach Josip, Gjeri Gjuro, Gjurgjević } \\
\text { Valek, Hajduk Ivo, Markulin Josip, Matoić } \\
\text { Andro, Novak Valek, Ornig Ante, Radivoj } \\
\text { Mato, Tremski Stjepan, Vaščić Jakob, } \\
\text { Vitković Franjo }\end{array}$ & 15 & 1 & 16 \\
\hline Čohači & Kuharić Nikola & 1 & - & 1 \\
\hline Dimnjačari & Križa Josip, Vučer Janko & 2 & - & 2 \\
\hline Fijakeristi & Kleinrat Gjuro & 1 & - & 1 \\
\hline
\end{tabular}

19 Zoran HOMEN, Obitelj Kiepach od Haselburga u Križevcima. Katalog izložbe iz ostavština obitelji. Gradski muzej Križevci - Likovna galerija, 22. IV. - 15. V. 2004., str. 13-14. 
Rad Hrvat. akad. znan. i umjet. Razred za druš. znan. 55=545(2021) : 31-102

\begin{tabular}{|c|c|c|c|c|}
\hline Gostioničari & Eisenberg Vinko & 1 & 3 & 4 \\
\hline Kišobranari & Jelić Vid & 1 & - & 1 \\
\hline Kitničari & Lándler Ilka & 1 & - & 1 \\
\hline Klobučari & $\begin{array}{l}\text { Crnčić Filiip, Crnajšek Franjo, Golubić } \\
\text { Josip, Ländler Ilka, Medvedec Nikola, } \\
\text { Milošin Nikola, Varović Ivan }\end{array}$ & 7 & 1 & 8 \\
\hline Kobasičari & Fintić Blaž, Gerstmann Vjekoslav & 2 & - & 3 \\
\hline Kolari & $\begin{array}{l}\text { Angjelić Franjo, Baštek Mijo, Hoić Jakob, } \\
\text { Imper Jakob, Kontić Gjuro, Kovačić Franjo, } \\
\text { Kranjčević Grga, Križ Franjo, Mekovec } \\
\text { Jakob, Pašta Mato, Peremin Dragutin, } \\
\text { Sabodi Jakob, Šofnekar Lujo, Trumber } \\
\text { Aleksa, Vrbančić Mato }\end{array}$ & 15 & 15 & 30 \\
\hline Kotlari & Matijević Ivo & 1 & - & 1 \\
\hline Kovači & $\begin{array}{l}\text { Buntak Grga, Forko Vatroslav, Herjavić } \\
\text { Stjepan, Kos Janko, Knežanek Josip, Surinić } \\
\text { Franjo, Zidarić Stjepan }\end{array}$ & 7 & 42 & 49 \\
\hline Kožari & Tomić Vjekoslav & 1 & - & 1 \\
\hline Krčmari & $\begin{array}{l}\text { Blažinčić Stjjepan, Bogović Lacko, Colarić } \\
\text { Slavoljub, Dončić Franjo, Figarac Tereza, } \\
\text { Forko Stjepan, Gjurgjević Vilim, Gold Josip, } \\
\text { Golubić Ante, Golubić Josip, Gročić Franjo, } \\
\text { Herjavić Stjepan, Heruc Gjuro, Heruc Luka, } \\
\text { Hlepaić Josip, Horvat Mirko, Hoić Luka, Ivić } \\
\text { Mijo, Jakopović Gjuro, Kiepach pl. Josip, } \\
\text { Konfić Josip, Kos Janko, Kovačić Franjo, } \\
\text { Kovačić Klara, Kuntić Lacko, Lauš Josip, } \\
\text { Lugomer Mirko, Lugomer Mio, Lugomer } \\
\text { Valent, Markulin Mio, Mehavec Josip, } \\
\text { Orahovački Luka, Pernjak Gjuro, Plohlin } \\
\text { Mirko, Podcajt Ante, Popović Nikola, } \\
\text { Somodji Lacko, Sokač Mirko, Stelcar Vera, } \\
\text { Stern Hirko, Šimunić Josip, Šimunčić Luka, } \\
\text { Šofneker Ljudevit, Šušković Ante, Tepeš Mio, } \\
\text { Višnić Cilika, Zorko Mirko }\end{array}$ & 48 & 163 & 211 \\
\hline Krojači & $\begin{array}{l}\text { Čamić Jakob, Gjöri Janko, Grinec Mato, } \\
\text { Gjurić Ivo, Harča Ante, Harča Nikola, } \\
\text { Herma Vilim, Kratohvil Josip, Kraus Mavro, } \\
\text { Mihajlić Miko, Pavliček Ante, Pavliček } \\
\text { Franjo, Pavliček Mirko, Perš Johan, Plohlin } \\
\text { Mirko, Simpek Josip, Steiner Josip, Šulković } \\
\text { Pavel, Titl Josip, Weinberger Dragutin. }\end{array}$ & 20 & 5 & 25 \\
\hline Krznari & Schönbvaum S., Dužanec Stjepan & 2 & - & 2 \\
\hline
\end{tabular}


Rad Hrvat. akad. znan. i umjet. Razred za druš. znan. 55=545(2021) : 31-102

Mira Kolar-Dimitrijević: Popis obrtnika na području današnje Koprivničko-križevačke županije 1890. godine

\begin{tabular}{|c|c|c|c|c|}
\hline $\begin{array}{l}\text { Kupališni } \\
\text { vlasnici }\end{array}$ & Gotal Bolto & 1 & - & 1 \\
\hline Ljekarnici & Suhomel J. & 1 & 1 & 2 \\
\hline Limari & $\begin{array}{l}\text { Majer Ante, Majer Dragutin, Majer Petar, } \\
\text { Schwarz Lavoslav }\end{array}$ & 4 & 10 & 14 \\
\hline Lončari & $\begin{array}{l}\text { Čavljak Mirko, Fiember Luka, Forko Tomo, } \\
\text { Hegedić Bolto, Horvat Ferdo, Horvat } \\
\text { Jakob, Košenjak Stjepan, Kotinec Gjuro, } \\
\text { Kozar Gjuro, Kuten Franjo, Malčević Grga, } \\
\text { Novak Gjuro, Novak Stjepan, Novosel Vid, } \\
\text { Novaković Mato, Prošek Gjuro, Sekelj Tomo }\end{array}$ & 17 & 10 & 27 \\
\hline Medičari & $\begin{array}{l}\text { Eisenmajer Viktor, Lunaček N., Zenta } \\
\text { Vjekoslav }\end{array}$ & 3 & - & 3 \\
\hline Mesari & $\begin{array}{l}\text { Heruc Martin, Heruc Valek, Hirschl } \\
\text { Vatroslav, Jakopović Ante, Kolarić Ivan, } \\
\text { Kolarić Stjepan, Logomer Ante, Logomer } \\
\text { Gjuro, Lustig Julio, Lustig Jakob, Novak } \\
\text { Gjuro, Pavljak Imbro, Pavljak Tomo, Premrl } \\
\text { Dragutin, Slaviček Mio, Slaviček Pavao }\end{array}$ & 16 & 32 & 48 \\
\hline Mlinari & $\begin{array}{l}\text { Bengez Ante, Bocak Stjepan, Majević } \\
\text { Marko, Vaupotić Hinko }\end{array}$ & 4 & 55 & 59 \\
\hline Nožari & Herlec Franjo & 1 & - & 1 \\
\hline Opančari & $\begin{array}{l}\text { Car Mirko, Forko Valent, Habdaj Stjepan, } \\
\text { Heruc Luka, Hlebčić Josip, Katanec Ante, } \\
\text { Kolar Mirko, Kolar Jakob, Kranjčina Mio, } \\
\text { Orehovački Luka, Pernjak Gjuro, Poljak } \\
\text { Tomo, Sekelj Dragutin, Sviličić Mirko, } \\
\text { Vugrinčić Mijo }\end{array}$ & 15 & 13 & 28 \\
\hline $\begin{array}{l}\text { Ciglari - } \\
\text { ciglane i } \\
\text { ploče za } \\
\text { peći ** }\end{array}$ & Braća Grahor i dr. & 1 & . & 1 \\
\hline $\begin{array}{l}\text { Parni } \\
\text { mlinovi** }\end{array}$ & - & - & 3 & 3 \\
\hline Pekari & Heruc Lujo, Herščak Ivan, Križek Šandor & 3 & 2 & 5 \\
\hline Pivari** & Katz i sinovi & 1 & - & 1 \\
\hline Poduzetnici & Hamdija Luka & 1 & 5 & 6 \\
\hline Postolari & $\begin{array}{l}\text { Banek Martin, Buda Valek, Habdija Šandor, } \\
\text { Hegedić Dragutin, Jurkas Gjuro, Jagodić } \\
\text { Božo, Jurak Mio, Kiš Nikola, Kohor Josip, } \\
\text { Kolšek Ivan, Komad Gjuro, Kunst Mirko, } \\
\text { Majer Slavoljub, Matus Mato, Mihalić Franjo, } \\
\text { Ranogajec Mirko, Senjarić Niko, Strahinščak } \\
\text { Josip, Svedružić Vjekoslav, Zorko Mirko. }\end{array}$ & 20 & 20 & 40 \\
\hline
\end{tabular}


Rad Hrvat. akad. znan. i umjet. Razred za druš. znan. 55=545(2021) : 31-102

\begin{tabular}{|c|c|c|c|c|}
\hline $\begin{array}{l}\text { Sedlari i } \\
\text { remenari }\end{array}$ & $\begin{array}{l}\text { Babok Franjo, Bišćan Slavoljub, Colarić } \\
\text { Slavoljub, Fintić Valentin, Golubić Ante, } \\
\text { Jandrašić Miko, Mihinac Andro, Milihram } \\
\text { Ivan, Prišl Vatroslav }\end{array}$ & 9 & 1 & 10 \\
\hline Soboslikari & Marketi Ivan & 1 & - & 1 \\
\hline Stolari & $\begin{array}{l}\text { Baštek Martin, Bogović Lacko, Gorički } \\
\text { Franjo, Habdija Šandor, Hechtl Dragutin, } \\
\text { Kovač Lujo, Ornik Dragutin, Res Gabro, } \\
\text { Višnić Milan }\end{array}$ & 9 & 12 & 21 \\
\hline Tesari & Brumen Josip, Urenak Primna, Žganjer Josip & 3 & 4 & 7 \\
\hline Tkalci & $\begin{array}{l}\text { Brletić Valek, Gjurgjević Vilim, Ivić Mijo, } \\
\text { Kohar Dragutin, Mamek Gabro, Podboj } \\
\text { Franjo }\end{array}$ & 6 & - & 6 \\
\hline Tokari & Mikelj Ante, Rebenklauber Vjakoslav & 2 & - & 2 \\
\hline Urari & Marjivić Josip, Trnenić Gjuro & 2 & - & 2 \\
\hline Užari & $\begin{array}{l}\text { Horvat Josip, Horvat Vid, Kovačić Alekso, } \\
\text { Škulj Dragutin }\end{array}$ & 4 & - & 4 \\
\hline Vapnari & Mileusnić Vaso & 1 & - & 1 \\
\hline Zakupnici & - & - & 1 & 1 \\
\hline Zdenčari & - & - & 2 & 2 \\
\hline Zidari & $\begin{array}{l}\text { Cetevržnik Martin, Čičula Ivan, Čuček } \\
\text { Tomo, Dietrich Ivan, Dremeš Franjo, Kušter } \\
\text { Franjo, Lukačić Franjo }\end{array}$ & 7 & 1 & 8 \\
\hline Ukupno & & 283 & 400 & 683 \\
\hline
\end{tabular}

* G. JUSTUS, L. STROHMAYER, Adresar obrtnog i poslovnog svieta u Hrvatskoj g. 1890, Zagreb, 1891., str. 49-210.- Podcrtana su ženska imena.

** Tvornice

Iz tablice 6 možemo iščitati da su u Gradu Križevcima bila 283 obrtnika, svrstana u 49 struka, ali da u Križevcima nije bilo zdenčara, zakupnika zemlje i nekih drugih obrtnika, dok u kotaru pak nije bilo češljara, četkara, čohača, dimnjačara, fijakerista, kobasičara, kotlara, krojača, krznara, medičara, nožara, pivara, soboslikara, tkalaca, tokara, urara, užara ni vapnara, te se za te usluge moralo ići u Križevce ili se sve to obavljalo u kućnoj radinosti. Obrti su bili u rukama pojedinaca, ali se javljaju i obitelji kao nosioci obrtne radnje, koja već ima tvornički karakter, kao što su ciglana i izrada ploča za peći braće Grahor, koji rade za Zagreb, te pivovara Katz i sinovi. Mlinovi su još na razini obrta u rukama plemićkih obitelji ili crkve. Iako u Križevcima živi nekoliko obitelji koje imaju 
predikat plemstva, ali koje se ne bave obrtom, izuzev Josipa Kieipacha, koji drži krčmu u Križevcima i koji je zato u povoljnijem materijalnom stanju nego onaj dio plemstva koji se nije uključio u proizvodnju i trgovinu smatrajući to nedostojnim poslom. Sve što je bilo važno za život moglo se nabaviti, a i popraviti kod križevačkih obrtnika, što je, dakako, potvrđivalo dobar standard Križevčana i nakon što su prestali biti sjedište Bjelovarsko-križevačke županije 1886. Očito je da su Križevci, smješteni podno vinorodnog Kalnika, bili privlačno mjesto za život, nalazeći se na glavnoj pruzi Mađarska - Rijeka, te lako dostupni i iz Zagreba i iz Koprivnice. Dakako, nekih zanimanja ipak nije bilo.

Žene rijetko nalazimo kao obrtnice i u gradu se u svojstvu obrtnica vodi svega šest žena. Zbog rijetkosti njihovih djelatnosti, možemo ih nabrojiti: Ilka Ländler bila je kitničarka, a izrađivala je šešire. Kao krčmarice djeluju Tereza Figarac, Klara Kovačić, Vera Stelcar i Ciliga Višnjić. Primna Urenak vodila je tesarski posao, vjerojatno kao udovica uz pomoć poslovođe. Žena nema među tkaljama ni među krojačima, iako su vjerojatno radile u radionicama svojih muževa kao i u cehovsko doba.

Prema Adresaru, Josip pl. Kiepach imao je krčmu u Križevcima, ali i u Gregurovcu. Zanimljivo je da njegovoj kući u Križevcima, gdje je bila u 18. stoljeću glasovita Magdalenićeva manufaktura keramičkih peći, nema ni traga. Sudbina je tog dvorca tragična jer je srušen 1966., iako je mogao biti i danas veliki i značajni muzej Prigorja. Spominje se i ugostiteljski objekt Grkokatoličke biskupije u Tkalcu i krčme nekih općina, dakle zajednica mještana.

\section{Brojno stanje obrtnika u Kotaru Križevci 1890. godine.}

Broj obrtnika u kotaru bez grada Križevaca bio je viši nego u gradu, ali je struktura bila jednostavnija i prevladavali su krčmari, kovači i zidari. Ipak, nalazimo i neke obrtnike čijih struka nije bilo u gradu Križevcima, pa su Križevčani pozivali te obrtnike u Križevce. No uočava se i da su i upravne općine Raven, Sveti Ivan Žabno, Sveti Petar Orehovec, Vojakovec i Vrbovec, na čijim je područjima bilo mnogo sela, a u Vojakovcu i zaselaka, imale mnogo obrtnika.

Kako bi se dobio kompletan uvid u navedeno, tablica 7 uređena je tako da se prvo navodi obrtnička struka i onda sela u kojima ima te vrste obrtnika, a kako bi se mogla rekonstruirati i pripadnost pošti, koja se zbog važnosti uvijek navodi u Adresaru jer se komunikacija s upravnim vlastima, ali i komitentima odvijala preko pošte, u tablici se navode i nadležne pošte, a to su Križevci, Raven, Sv. Ivan Žabno, Vrbovec, Sv. Petar Orehovec, Majur i Gradec. To je područje u odnosu na druga bilo bolje povezano. Nažalost, u Adresaru nema drugih podataka. 
Rad Hrvat. akad. znan. i umjet. Razred za druš. znan. 55=545(2021) : 31-102

Mira Kolar-Dimitrijević: Popis obrtnika na području današnje Koprivničko-križevačke županije 1890. godine

Tablica 7. Obrtnici u Križevačkom kotaru bez grada Križevaca 1890.*

\begin{tabular}{|c|c|c|c|}
\hline Obrti & $\begin{array}{c}\text { Mjesto na } \\
\text { području kotara }\end{array}$ & Pošta & Ime i prezime obrtnika \\
\hline \multirow[t]{2}{*}{ Bačvari } & Boić & $\begin{array}{l}\text { Sveti Ivan } \\
\text { Žabno }\end{array}$ & Baršić Stjepan \\
\hline & Vrbovec & Vrbovec & Butija Gjuro \\
\hline Bravari & Vrbovec & Vrbovec & Bach Antun, Kokot Antun \\
\hline \multirow[t]{2}{*}{ Ciglari } & Lojnica, & Vrbovex & Altabas Ivan, Levačić Mato,Lisičak Vid \\
\hline & Preseka & Raven & Rössler Antun \\
\hline Čizmari & Rakovec & Vrbovec & Hechtl Ivan \\
\hline \multirow[t]{3}{*}{ Gostioničari } & Cirkvena & $\begin{array}{l}\text { Sveti Ivan } \\
\text { Žabno }\end{array}$ & Milivojević Marko, \\
\hline & Roviište & $\begin{array}{l}\text { Sveti Ivan } \\
\text { Žabno }\end{array}$ & Kafka Drago \\
\hline & Vrbovec & Vrbovec & Berković Franjo \\
\hline Klobučari & Vrbovec & Vrbovec & Hechtl Gjuro \\
\hline \multirow[t]{8}{*}{ Kolari } & Gradec & Gradec & $\begin{array}{l}\text { Fugaj Tomo, Masnec Mato, Vukasović } \\
\text { Rade }\end{array}$ \\
\hline & Haganj & $\begin{array}{l}\text { Sveti Ivan } \\
\text { Žabno }\end{array}$ & Drmačić Simo, Sinković Dragutin \\
\hline & $\begin{array}{l}\text { Kebelj, } \\
\text { Farkaševac }\end{array}$ & $\begin{array}{l}\text { Sveti Ivan } \\
\text { Žabno }\end{array}$ & Popović Jula \\
\hline & Kraljevac & $\begin{array}{l}\text { Sveti Ivan } \\
\text { Žabno }\end{array}$ & Kamenović Mijo \\
\hline & Lojnica & Vrbovec & Schäfer Franjo \\
\hline & Poljana & Vrbovec & Lepotinec Luka, Nežić Štef \\
\hline & $\begin{array}{l}\text { Sveti Petar } \\
\text { Orehovec }\end{array}$ & $\begin{array}{l}\text { Petar } \\
\text { Orehovec }\end{array}$ & Lalić Franjo \\
\hline & Vrbovec & Vrbovec & $\begin{array}{l}\text { Basarić August, Lacković Tomo, Novosel } \\
\text { M., Soviček Lovro }\end{array}$ \\
\hline \multirow[t]{4}{*}{ Kovači } & Brezina & $\begin{array}{l}\text { Sveti Ivan } \\
\text { Žabno }\end{array}$ & Knežević Lazo, Šimunović Gjuro \\
\hline & Carev dar & Majur & Lazić Gjuro \\
\hline & Cirkvena & $\begin{array}{l}\text { Sveti Ivan } \\
\text { Žabno }\end{array}$ & Nježak Pavao, Valiček Ferdo \\
\hline & Cubinec & $\begin{array}{l}\text { Sveti Ivan } \\
\text { Žabno }\end{array}$ & Hrvoj Toma \\
\hline
\end{tabular}


Rad Hrvat. akad. znan. i umjet. Razred za druš. znan. 55=545(2021) : 31-102 Mira Kolar-Dimitrijević: Popis obrtnika na području današnje Koprivničko-križevačke županije 1890. godine

\begin{tabular}{|c|c|c|c|}
\hline & Cugavac & $\begin{array}{l}\text { Sveti Ivan } \\
\text { Žabno }\end{array}$ & Dobrinić Tomo. Škarić Stanko \\
\hline & Glog Novi & $\begin{array}{l}\text { Sveti Ivan } \\
\text { Žabno }\end{array}$ & Sokač Josip \\
\hline & Gradec & Gradec & $\begin{array}{l}\text { Bačun Jakob, Marković Andro, } \\
\text { Vinceković Martin }\end{array}$ \\
\hline & Gušćerovec & Orehovec & Javor Mio \\
\hline & Haganj & $\begin{array}{l}\text { Sveti Ivan } \\
\text { Žabno }\end{array}$ & $\underline{\text { Poha Ana i Imbro }}$ \\
\hline & Hruškovica & Gradec & Kunfić Ivo \\
\hline & $\begin{array}{l}\text { Kebelj - } \\
\text { Farkaševac }\end{array}$ & $\begin{array}{l}\text { Sveti Ivan } \\
\text { Žabno }\end{array}$ & Ruškovac Gašpar \\
\hline & Kraljevec & $\begin{array}{l}\text { Sveti Ivan } \\
\text { Žabno }\end{array}$ & Markulović Joso \\
\hline & Kućari & Raven & Pavlas Tomo \\
\hline & Marinovac & Majur & Kunjačić Stefan \\
\hline & Negovec & Vrbovec & Petoljak Miko \\
\hline & Poljana & Vrbovec & $\begin{array}{l}\text { Kluković Gjuro, Octenjak Ivan, Sarkanji } \\
\text { Pavao }\end{array}$ \\
\hline & Rakovac & Vrbovec & Tošnik Antun \\
\hline & Raven & Gradec & Dečak Mato \\
\hline & $\begin{array}{l}\text { Sveti Ivan } \\
\text { Žabno }\end{array}$ & $\begin{array}{l}\text { Sveti Ivan } \\
\text { Žabno }\end{array}$ & $\begin{array}{l}\text { Košćević Imbro, Koščević Miško, Simčić } \\
\text { Franjo }\end{array}$ \\
\hline & $\begin{array}{l}\text { Sveti Petar } \\
\text { Čvrstec }\end{array}$ & Majur & Ciljenak Stefo, Eumin Stevo \\
\hline & Špiranec & Križevci & Kunjak Tomo, Fureš Mato \\
\hline & Vojakovac & Križevci & $\begin{array}{l}\text { Gredelj Josip, Radotović Franjo, Švagelj } \\
\text { Imbro, Vavra Franjo }\end{array}$ \\
\hline & Vrbovec & Vrbovec & $\begin{array}{l}\text { Frajzman Mio, Kiš Jozo, Palenik Franjo, } \\
\text { Rinkovec Andro, Sabal Andro, Vugrinović } \\
\text { Martin }\end{array}$ \\
\hline \multirow[t]{3}{*}{ Krčmari } & Apatovac & Križevci & Löw Vilim \\
\hline & $\begin{array}{l}\text { Bojnikovec, p. } \\
\text { Križevci }\end{array}$ & Raven & Jagodić Ilija \\
\hline & Bolč & $\begin{array}{l}\text { Sveti Ivan } \\
\text { Žabno }\end{array}$ & $\begin{array}{l}\text { Bastarić N., Gjurički Mato, Kos Franjo, } \\
\text { Šiljak Lazo }\end{array}$ \\
\hline
\end{tabular}


Rad Hrvat. akad. znan. i umjet. Razred za druš. znan. 55=545(2021) : 31-102

Mira Kolar-Dimitrijević: Popis obrtnika na području današnje Koprivničko-križevačke županije 1890. godine

\begin{tabular}{|c|c|c|}
\hline Brekovčina & Križevci & $\begin{array}{l}\text { Jelenčić Imbro, Kohn Herman, Tizek } \\
\text { Gjuro }\end{array}$ \\
\hline Brezine & I. Žabno & $\begin{array}{l}\text { Dragoner Sami, Filipović Simo, Perčec } \\
\text { Franjo }\end{array}$ \\
\hline Carevdar & Majur & Pozel Antun, Štimac Antun \\
\hline Cirkvena & I. Žabno & $\begin{array}{l}\text { Dragoner Samojlo, Kozerek Imbro, } \\
\text { Kurašić Tomo, Zrinski Luka }\end{array}$ \\
\hline Cubinec & $\begin{array}{l}\text { Sveti Ivan } \\
\text { Žabno }\end{array}$ & $\begin{array}{l}\text { Belaj Stjepan, Funtek Jakob, Trninić Mio, } \\
\text { Turčić Kata }\end{array}$ \\
\hline Cugavac & $\begin{array}{l}\text { Sveti Ivan } \\
\text { Žabno }\end{array}$ & $\begin{array}{l}\text { Dobrnić Josip, Popovečki Franjo, } \\
\text { Prekvarić Mara, Sestrić Ivan, Srum Adolf }\end{array}$ \\
\hline Dijaneš & Vrbovec & Klobučar Josip \\
\hline Dijankovec & Križevci & Beck Jakob \\
\hline Dubovec & Križevci & Blažinčić Tomo \\
\hline Erdavec & Križevci & Finkelstein Roza, Posavec Ivan \\
\hline Farkaševac & $\begin{array}{l}\text { Sveti Ivan } \\
\text { Žabno }\end{array}$ & Ivanović Aleksa, Novak Antun \\
\hline Finčevec & Križevci & Koretić Ivo, Nemčić Kata \\
\hline Fodrovec & Orehovec & Matoić Gjuro \\
\hline Fuka & $\begin{array}{l}\text { Sveti Ivan } \\
\text { Žabno }\end{array}$ & Pupian Martin \\
\hline Glog Novi & $\begin{array}{l}\text { Sveti Ivan } \\
\text { Žabno }\end{array}$ & Novaković Joso, Remuš Imbrto \\
\hline Glog Stari & $\begin{array}{l}\text { Sveti Ivan } \\
\text { Žabno }\end{array}$ & Dobrinić Josip \\
\hline Glogovnica & Križevci & $\begin{array}{l}\text { Cvetković Imbro, Gjurin Marko, Sčetar } \\
\text { Stjepan }\end{array}$ \\
\hline Gradec & Gradec & $\begin{array}{l}\text { Bučić Pavao, Fugaj Tomo, Gospoštija } \\
\text { gradačka, Ström Adolf }\end{array}$ \\
\hline Grgurovac & Križevci & Kiepach Josip \\
\hline Gušćerovec & Orehovec & Javor Mio \\
\hline Habjanovac & $\begin{array}{l}\text { Sveti Ivan } \\
\text { Žabno }\end{array}$ & Popović Stanko \\
\hline Hrsovo & $\begin{array}{l}\text { Sveti Ivan } \\
\text { Žabno }\end{array}$ & Posavec Kata \\
\hline Ivančani & $\begin{array}{l}\text { Sveti Ivan } \\
\text { Žabno }\end{array}$ & $\begin{array}{l}\text { Hajduković Marko, Juranić Andro, Tomaš } \\
\text { Stjepan, Veseli Mato, Veseli Miško, } \\
\text { Veroer Bartol, Vernes Joso }\end{array}$ \\
\hline
\end{tabular}


Rad Hrvat. akad. znan. i umjet. Razred za druš. znan. 55=545(2021) : 31-102

Mira Kolar-Dimitrijević: Popis obrtnika na području današnje Koprivničko-križevačke županije 1890. godine

\begin{tabular}{|c|c|c|}
\hline Ivančani & $\begin{array}{l}\text { Sveti Ivan } \\
\text { Žabno }\end{array}$ & Vodogažec Jandro, Vodogažec Joco \\
\hline Jales Vrbovec & Gradec & Novak Ivan, Schwarz Leopold \\
\hline Kalnik & Orehovec & Bek Žiga \\
\hline $\begin{array}{l}\text { Kebelj - } \\
\text { Farkaševac }\end{array}$ & $\begin{array}{l}\text { Sveti Ivan } \\
\text { Žabno }\end{array}$ & Poličić Mio, Zagorac Mato \\
\hline Kraljevac & $\begin{array}{l}\text { Sveti Ivan } \\
\text { Žabno }\end{array}$ & $\begin{array}{l}\text { Ban Jovo, Dobina Mio, Dobričić Ignac, } \\
\text { Gragurić Ivan, Jemeršić Franjo, Jemeršić } \\
\text { Mio, Kolar Franjo, Kolar Pavao, Pakšinić } \\
\text { Evo, Sutlarić Vinko, Šafar Stjepan, Trajbar } \\
\text { Franjo, Tukanec Mato, }\end{array}$ \\
\hline Lemeš & Križevci & Raić Tomo \\
\hline Majurec & Križevci & Sokač Martin \\
\hline Marinovac & Križevci & Kamenarić Jozo \\
\hline Medja & Orehovec & Križek Mirko, Mrazović Valek \\
\hline Miholjec & Orehovec & Blazina Ana, Sodić Ivan i Reza Sodić \\
\hline Meminska & Majur & Vojaković Petar \\
\hline Negovec & Vrbovec & Kranjc Martin \\
\hline Pirakovec & Vrbovec & Smirić Stjepan \\
\hline Poljana sela & Vrbovec & Perko Ivan, Škrinjarić Gjuro, Vitez Ivan \\
\hline Potočec & Križevci & Majdak Marko, Pećarić Blaž \\
\hline Predavac & I. Žabno & $\begin{array}{l}\text { Martinić Gjuro, Martinić Stjepan, } \\
\text { Rozenberg Ignac }\end{array}$ \\
\hline Preseka - Raven & Raven & Mayer Makso, Rössler Antun, Stekar Josip \\
\hline Rakovec & Vrbovec & $\begin{array}{l}\text { Adam Dragutin, Čavljak Andro, Hernstein } \\
\text { Helena, Feinberg Andro }\end{array}$ \\
\hline Raščani & Križevci & Gjurković Blaž \\
\hline Raven & Križevci & $\begin{array}{l}\text { Funtek Luka, Kaprić Andro, Neuman Julio, } \\
\text { Smerda Josip, Šestak Mio, Valjak Adam }\end{array}$ \\
\hline Rovišće & $\begin{array}{l}\text { Sveti Ivan } \\
\text { Žabno }\end{array}$ & Turić Jakob \\
\hline Samoborci & Vrbovec & Ceiger Tomo \\
\hline Selnica, & Orehovec & $\begin{array}{l}\text { Fijan Josip, Habajec Imbro, Hoić Janko, } \\
\text { Kamenar Janko,Weiss Gustav }\end{array}$ \\
\hline $\begin{array}{l}\text { Sveta Helena - } \\
\text { Vojakovac }\end{array}$ & Križevci & $\begin{array}{l}\text { Blažun Janko, Goršić Pavao, Habdija } \\
\text { Bartol, Horvat Joso, Kamenović Imbro, } \\
\text { Kamenović Pavo, Kramer Martin, Opat } \\
\text { Juraj, Perharić Franjo, Salaj Imbro, Stručić } \\
\text { Janko, Stručić Mato, Švagelj Kazimir, } \\
\text { Vrbančić Ivan }\end{array}$ \\
\hline
\end{tabular}


Rad Hrvat. akad. znan. i umjet. Razred za druš. znan. 55=545(2021) : 31-102

Mira Kolar-Dimitrijević: Popis obrtnika na području današnje Koprivničko-križevačke županije 1890. godine

\begin{tabular}{|c|c|c|c|}
\hline & $\begin{array}{l}\text { Sveti Ivan } \\
\text { Žabno }\end{array}$ & $\begin{array}{l}\text { Sveti Ivan } \\
\text { Žabno }\end{array}$ & $\begin{array}{l}\text { Koščević Niko, Koščević Vinko, Kućan P., } \\
\text { Peašinović Pavao, Ström Adolf, Škrinjar } \\
\text { Mato }\end{array}$ \\
\hline & $\begin{array}{l}\text { Sveti Petar } \\
\text { Orehovec }\end{array}$ & Orehovec & $\begin{array}{l}\text { Fodroci pl. Šandor, Janšćak Valek, } \\
\text { Kamenović Gjuro, Szabo Vendelin, } \\
\text { Tremski Kata }\end{array}$ \\
\hline & Špiranec & Križevci & Breuk Ivo, Schlinger Vjekoslav \\
\hline & Tkalec & Križevci & Biskupija Križevačka \\
\hline & Trema & Križevci & Horvat Tomo, Sokač Tomo \\
\hline & Tučanik & $\begin{array}{l}\text { Sveti Ivan } \\
\text { Žabno }\end{array}$ & 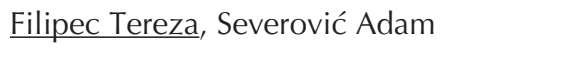 \\
\hline & Varoš -Vrbovec & Vrbovec & Maješ Ljudevit \\
\hline & $\begin{array}{l}\text { Velika dol. } \\
\text { Raven }\end{array}$ & Raven & Hoholač Ivan \\
\hline & Vojakovac & Križevci & Löwy Šimun \\
\hline & Vojnovec & Orehovec & $\underline{\text { Sokač Jana }}$ \\
\hline & Vrbovec & Vrbovec & $\begin{array}{l}\text { Bedeković Josip, Gorša Gjuro, Jalzić } \\
\text { Josip, Persoli Mio, Resnik Andro, Božanek } \\
\text { Antonija, Shutz Dragutin Štampfl Mato, } \\
\text { Valdec Stjepan }\end{array}$ \\
\hline & $\begin{array}{l}\text { Vukšinec - } \\
\text { Farkaševac }\end{array}$ & $\begin{array}{l}\text { Sveti Ivan } \\
\text { Žabno }\end{array}$ & Vucagić Lazo \\
\hline \multirow[t]{3}{*}{ Krojači } & Kraljevec & $\begin{array}{l}\text { Sveti Ivan } \\
\text { Žabno }\end{array}$ & Omers Ivan \\
\hline & $\begin{array}{l}\text { Sveti Ivan } \\
\text { Žabno }\end{array}$ & $\begin{array}{l}\text { Sveti Ivan } \\
\text { Žabno }\end{array}$ & $\begin{array}{l}\text { Forko Dragutin, Sedlaček Vencel, Šramek } \\
\text { Bernard }\end{array}$ \\
\hline & Vrbovec & Vrbovec & Brlečić Bolto \\
\hline Ljekarnici & Vrbovec & Vrbovec & Neuman Ferdinand $\mathrm{K}$. \\
\hline \multirow[t]{7}{*}{ Limari } & Cirkvena & I. Žabnol & Zrinski Luka \\
\hline & Gradec & Gradec & Kuharec Vid \\
\hline & Ivančani & $\begin{array}{l}\text { Sveti Ivan } \\
\text { Žabno }\end{array}$ & Posavec Andro \\
\hline & Rovišče & $\begin{array}{l}\text { Sveti Ivan } \\
\text { Žabno }\end{array}$ & Turić Jakov \\
\hline & Sveti Ivan & $\begin{array}{l}\text { Sveti Ivan } \\
\text { Žabno }\end{array}$ & Gogić Franjo, Koščević Gjuro \\
\hline & $\begin{array}{l}\text { Sveti Petar } \\
\text { Čvrstec }\end{array}$ & Križevci & Cumin Gjuro \\
\hline & Vojakovac & Križevci & Hlebec Gjuro \\
\hline
\end{tabular}


Rad Hrvat. akad. znan. i umjet. Razred za druš. znan. 55=545(2021) : 31-102

Mira Kolar-Dimitrijević: Popis obrtnika na području današnje Koprivničko-križevačke županije 1890. godine

\begin{tabular}{|c|c|c|c|}
\hline & Vrbovec & Vrbovec & Fintić Tomo \\
\hline & Zvornik & $\begin{array}{l}\text { Sveti Ivan } \\
\text { Žabno }\end{array}$ & Piškorić Franjo \\
\hline \multirow[t]{25}{*}{ Mesari } & Apatovac & Križevci & Löw Vilim \\
\hline & Bojnikovec & Križevci & Heruc Blaž \\
\hline & Bolč & $\begin{array}{l}\text { Sveti Ivan } \\
\text { Žabno }\end{array}$ & Gjuričić Mato \\
\hline & Brckovčina & Križevci & Kohn Herman \\
\hline & Brezine & $\begin{array}{l}\text { Sveti Ivan } \\
\text { Žabno }\end{array}$ & Perčec Franjo \\
\hline & Carevdar & Križevci & Pozel Antun, Štimac Antun \\
\hline & Cirkvena & $\begin{array}{l}\text { Sveti Ivan } \\
\text { Žabno }\end{array}$ & Milivojević Marko \\
\hline & Dubavac & Križevci & Blažinčić Mato \\
\hline & Fodrovec & Orehovec & Matoić Gjuro \\
\hline & Glogovnica & Križevci & Gjurin Marko, Sčetar Stjepan \\
\hline & Gradec & Gradec & Ström Adolf \\
\hline & $\begin{array}{l}\text { Gregurovec - } \\
\text { Raven }\end{array}$ & $\begin{array}{l}\text { Križevci } \\
\text { Raven }\end{array}$ & Futač Andro \\
\hline & Kalnik & Orehovec & Bek Žiga, Janščak Valek \\
\hline & Kemeš & Križevci & Golubić Gašpar, Slaviček Miško \\
\hline & Medja & Orehovec & Križek Mirko \\
\hline & Poljana & Vrbovec & Gold Franjo, Basur Imbro \\
\hline & Preseka - Raven & $\begin{array}{l}\text { Križevci i } \\
\text { Raven }\end{array}$ & Mayer Maks, Stekar Josip \\
\hline & Rakovac & Vrbovec & Čavljak Andro \\
\hline & Raven & $\begin{array}{l}\text { Križevci i } \\
\text { Raven }\end{array}$ & Neuman Julio \\
\hline & Rovište & $\begin{array}{l}\text { Sveti Ivan } \\
\text { Žabno }\end{array}$ & Kafka Dragutin \\
\hline & $\begin{array}{l}\text { Sveti Ivan } \\
\text { Žabno }\end{array}$ & $\begin{array}{l}\text { Sveti Ivan } \\
\text { Žabno }\end{array}$ & Peašinović Marko \\
\hline & $\begin{array}{l}\text { Sveti Petar } \\
\text { Orehovec }\end{array}$ & Orehovec & Kovačić Aleksa \\
\hline & Vojakovac & Križevci & Bonyhadi Jakov \\
\hline & Vojnovec & Orehovec & Sokač Imbro \\
\hline & Vrbovec & Vrbovec & Berković Franjo, Gorša Gjuro \\
\hline
\end{tabular}


Rad Hrvat. akad. znan. i umjet. Razred za druš. znan. 55=545(2021) : 31-102

Mira Kolar-Dimitrijević: Popis obrtnika na području današnje Koprivničko-križevačke županije 1890. godine

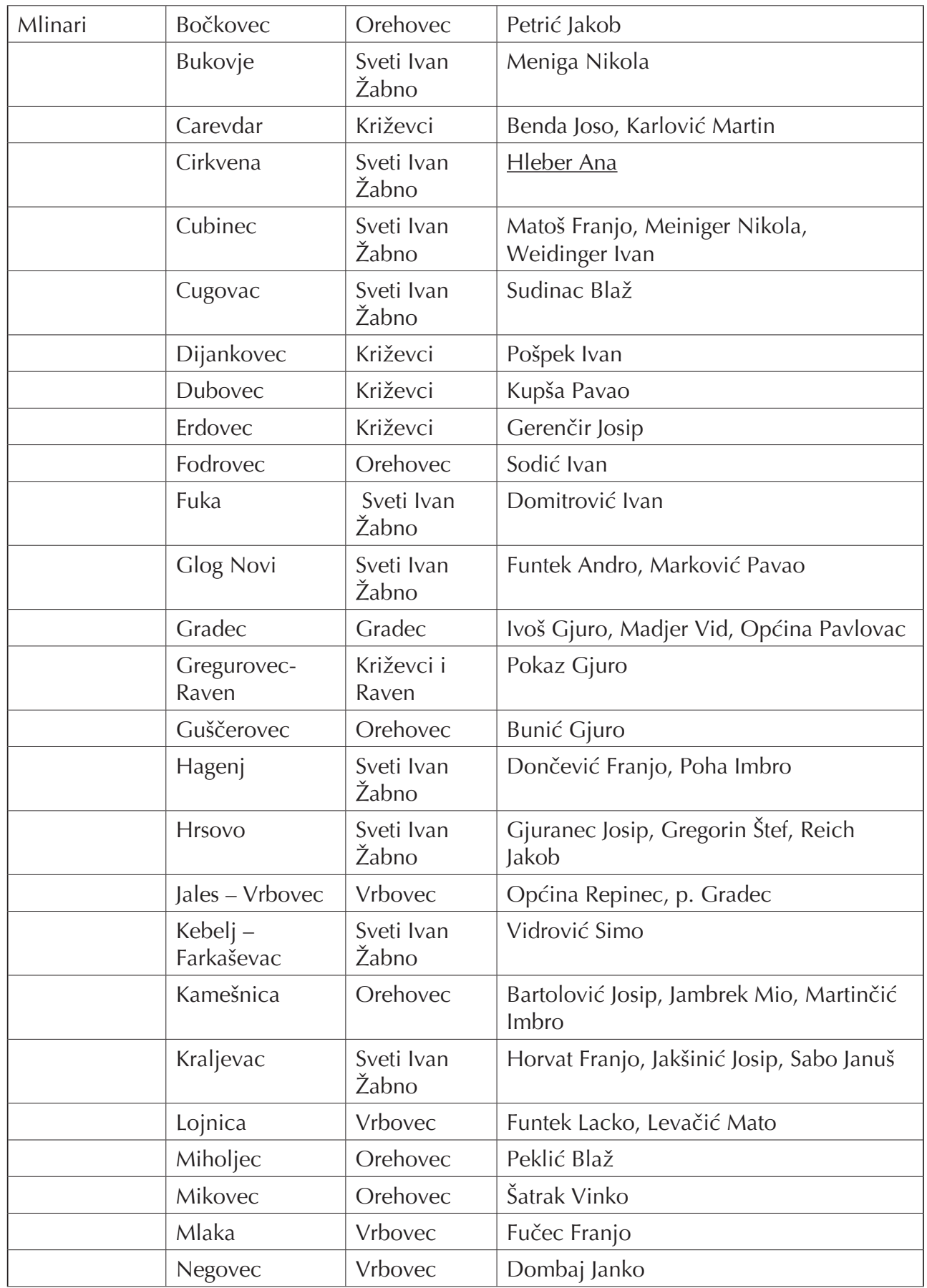


Rad Hrvat. akad. znan. i umjet. Razred za druš. znan. 55=545(2021) : 31-102

Mira Kolar-Dimitrijević: Popis obrtnika na području današnje Koprivničko-križevačke županije 1890. godine

\begin{tabular}{|c|c|c|c|}
\hline & $\begin{array}{l}\text { Osijek - } \\
\text { Vojakovec }\end{array}$ & Križevci & Vučićev mlin \\
\hline & Poljana & Vrbovec & Hrvoj Josip, Matoš Franjo \\
\hline & Potočac & Križevci & Petrić Tomo \\
\hline & $\begin{array}{l}\text { Sveti Ivan } \\
\text { Žabno }\end{array}$ & $\begin{array}{l}\text { Sveti Ivan } \\
\text { Žabno }\end{array}$ & Brečak Valent \\
\hline & Tkalec & Križevci & Podolski Blaž \\
\hline & Trema & Križevci & Pintar Štefo \\
\hline & Tučenik & $\begin{array}{l}\text { Sveti Ivan } \\
\text { Žabno }\end{array}$ & Brečak Valent, Sugović Štefan \\
\hline & Vojakovac & Križevci & $\begin{array}{l}\text { Benko Gjuro, Grobač Ana, Pintar Imbro, } \\
\text { Pintar Stjepan, }\end{array}$ \\
\hline & Zabrdje & $\begin{array}{l}\text { Sveti Ivan } \\
\text { Žabno }\end{array}$ & Kovačević Grga, Turk Štefan \\
\hline \multirow[t]{10}{*}{ Opančari } & Cirkvena & $\begin{array}{l}\text { Sveti Ivan } \\
\text { Žabno }\end{array}$ & Gjuričić Luka \\
\hline & Glog & $\begin{array}{l}\text { Sveti Ivan } \\
\text { Žabno }\end{array}$ & Karleuša Gajo \\
\hline & Gradec & Gradec & Fučec Štef \\
\hline & Hrsovo, & $\begin{array}{l}\text { Sveti Ivan } \\
\text { Žabno }\end{array}$ & Horvat Ivan, Jokić Nikola \\
\hline & Ivančani & $\begin{array}{l}\text { Sveti Ivan } \\
\text { Žabno }\end{array}$ & Horvat Josip, Knitl Stjepan \\
\hline & $\begin{array}{l}\text { Kebelj- } \\
\text { Farkaševac }\end{array}$ & $\begin{array}{l}\text { Sveti Ivan } \\
\text { Žabno }\end{array}$ & Zagorac Vinko \\
\hline & Pesek & Križevci & Šimunčić Gjuro \\
\hline & Rovišće & $\begin{array}{l}\text { Sveti Ivan } \\
\text { Žabno }\end{array}$ & Radaković Stevo, Rajaković Sava \\
\hline & Vrbovec & Vrbovec & Kuzmek Ivan \\
\hline & $\begin{array}{l}\text { Vukšinec - } \\
\text { Farkaševac }\end{array}$ & $\begin{array}{l}\text { Sveti Ivan } \\
\text { Žabno }\end{array}$ & Senjanac Joso \\
\hline \multirow[t]{3}{*}{$\begin{array}{l}\text { Mlinovi } \\
\text { parni** }\end{array}$} & $\begin{array}{l}\text { Stara Ves - } \\
\text { Raven }\end{array}$ & $\begin{array}{l}\text { Križevci i } \\
\text { Raven }\end{array}$ & Goldšmidt Samojlo \\
\hline & $\begin{array}{l}\text { Sveti Ivan } \\
\text { Žabno }\end{array}$ & $\begin{array}{l}\text { Sveti Ivan } \\
\text { Žabno }\end{array}$ & Ovčačik Franjo \\
\hline & Vrbovec & Vrbovec & Abeles Albert \\
\hline Pekari & Vrbovec & Vrbovec & Hund Adolf, Medvešek Martin \\
\hline \multirow[t]{2}{*}{ Poduzetnici } & Gradec & Gradec & Ström Adolf \\
\hline & Kalnik & Orehovec & Bek Žiga, \\
\hline
\end{tabular}


Rad Hrvat. akad. znan. i umjet. Razred za druš. znan. 55=545(2021) : 31-102

Mira Kolar-Dimitrijević: Popis obrtnika na području današnje Koprivničko-križevačke županije 1890. godine

\begin{tabular}{|c|c|c|c|}
\hline & Negovec & Vrbovec & Smirić Franjo \\
\hline & Rakovac & Vrbovec & Bedeković Josip \\
\hline & $\begin{array}{l}\text { Sveti Ivan } \\
\text { Žabno }\end{array}$ & $\begin{array}{l}\text { Sveti Ivan } \\
\text { Žabno }\end{array}$ & Ferari Ivan \\
\hline \multirow[t]{8}{*}{ Postolari } & Gradec & Gradec & Birt Vid, Bišanek Dragutin \\
\hline & Kraljevac & $\begin{array}{l}\text { Sveti Ivan } \\
\text { Žabno }\end{array}$ & Jurač Joso, Žganjac Tomo, Žurc Franjo \\
\hline & Poljana & Vrbovec & Šantović Joso \\
\hline & Raven & Raven & Dobrovoljni Ivan, Hofer Ivan, Višnić Petar \\
\hline & Rovišće & $\begin{array}{l}\text { Sveti Ivan } \\
\text { Žabno }\end{array}$ & Husak Tobias \\
\hline & $\begin{array}{l}\text { Sveti Ivan } \\
\text { Žabno }\end{array}$ & $\begin{array}{l}\text { Sveti Ivan } \\
\text { Žabno }\end{array}$ & Jankulica Mato, Polidno Franjo \\
\hline & Vojakovac & Križevci & Veinhard Mio \\
\hline & Vrbovec & Vrbovec & $\begin{array}{l}\text { Besan Tomo, Gaščić Vinko, Jalžić Josip, } \\
\text { Matešić Franjo, Mekola Hinko, Rišanek } \\
\text { Franjo, Rišanek Lujo }\end{array}$ \\
\hline $\begin{array}{l}\text { Sedlar, } \\
\text { remenar }\end{array}$ & Vrbovec & Vrbovec & Juston Franjo \\
\hline \multirow[t]{6}{*}{ Stolari } & Bolč & $\begin{array}{l}\text { Sveti Ivan } \\
\text { Žabno }\end{array}$ & Petrović Petar, Vukić Josip \\
\hline & Gradec & Gradec & Ipšeg Florijan \\
\hline & Rakovec & Vrbovec & Habe Antun \\
\hline & Raven & $\begin{array}{l}\text { Križevci i } \\
\text { Raven }\end{array}$ & Gabrovšek Mato \\
\hline & $\begin{array}{l}\text { Sveti Ivan } \\
\text { Žabno }\end{array}$ & $\begin{array}{l}\text { Sveti Ivan } \\
\text { Žabno }\end{array}$ & $\begin{array}{l}\text { Jankulica Gjuro, Šaban Marko, Župančić } \\
\text { Josip }\end{array}$ \\
\hline & Vrbovec & Vrbovec & $\begin{array}{l}\text { Gašćić Andro, Grace Karl, Levek Franjo, } \\
\text { Slanec Franjo }\end{array}$ \\
\hline \multirow[t]{2}{*}{ Tesari } & Raščani & Križevci & Šale Adam \\
\hline & Vrbovec & Vrbovec & Bauer Ignac, Bolf Bartol, Jereb Jozo \\
\hline Zakupnici & Medja, p. & Orehovec & Fröhlich Dragutin \\
\hline Zdenčari & Vrbovec & Vrbovec & Gabina Ivan, Knefler Ivan \\
\hline Zidari & Gradec & Gradec & Boškor Fric \\
\hline Ukupno & 400 & & \\
\hline
\end{tabular}

* G, JUSTUS, L. STROHMAYER, Adresar obrtnog i poslovnog svieta u Hrvatskoj g. 1890, Zagreb, 1891., str.49-210. Podcrtana su ženska imena. 
U kotaru nije bilo svih vrsta obrtnika, tako da su se neke usluge mogle dobiti tek u Križevcima ili Zagrebu, s kojim je nekadašnja Križevačka županija bila snažno povezana jer je imala istog velikog župana. Nekih novih vrsta obrtnika nije bilo, kao naprimjer ličilaca, fotografa, bojadisara tkanina, octara, slastičara, sodara, staklara, sapunara, ali nije bilo ni dimnjačara, pa su se ti poslovi obavljali vjerojatno u kućnoj radinosti ili naručenim dolaskom tih obrtnika. Nasuprot tome manjku uočava se izvanredno velik broj krčmara i gostioničara iz istog razloga kao i u drugim kotarima, te možemo zaključiti da su krčme bile mjesto sastajanja, ali i političko-društvenog informiranja, jer je Mažuranićev zakon od 1874. osigurao slobodu sastajanja ljudi radi javnih poslova. Uočavamo vrlo velik broj kovača, koji očito obavljaju raznovrsne usluge popravaka oruđa i alata, a vjerojatno i potkivanja konja.

Više je žena vodilo obrt na području kotara nego u gradu. Bilo ih je 15, i to ponajviše u krčmarskom obrtu. Navodimo obrtnice poimence: Kolarski obrt u Svetom Ivanu Žabnu vodi Jula Popović, a kovačku radnju u Haganju Ana Poha s Imbrom Pohom. Krčmarice u raznim mjestima bile su Kata Turčić, Mara Prekvarić, Roza Finkelstein, Kata Nemčić, Kata Posavec, Ana Blazina, Reza Sodić Helena Hernstein, Kata Tremski, Tereza Filipec, Jana Sokač, Antonija Božanek. Mlin u Cirkveni vodi Ana Hleber.

Vrijedi spomenuti da krčmu drži od veleposjednika, osim Josipa pl. Kiepacha u Križevcima i u Gregurovcu, i podban Šandor pl. Fodroci u Svetom Petru Orehovcu, a Grkokatolička biskupija u Tkalecu. Općina Repinec ima mlin.

Gotovo svi obrti u rukama su pojedinaca. Izuzetak čini Gradelja gospoštija, koja ima krčmu u Gradecu, te Grkokatolička biskupija u Križevcima, koja ima krčmu u Tkalecu. Općina Pavlovac imala je mlin u Gradecu, a Općina Repčinec mlin u Jalesu kod Vrbovca. Od plemstva Josip Kiepach drži krčmu u Gregurovcu, a Šandor pl. Fodroci krčmu u Svetom Petru Orehovcu. Nije isključeno da još nekoliko pripadnika plemstva drži slične radnje, ali se više ne kite plemićkim titulama jer se njihov materijalni status znatno promijenio te su mnogi životarili na svojim malim imanjima nadopunjavajući prihode radom u upravi i sudskim službama.

Židovi su uspješno zauzeli mnoge obrte i njihova je prisutnost nezaobilazna.

Zaključak koji se odnosi na obrtnike naveden je na kraju rada, pri čemu ističem da nisu iskorištene mnogobrojne mogućnosti ukazivanja zašto je neka struka dobro, a neka loše zastupljena na nekom području. Nisu analizirane ni nacionalnosti obrtnika, osim što je dan zaključak da je bilo obrtnika raznih narodnosti i raznih vjera, pa vjerojatno i jezika, te da se i na području Križevaca vršio snažan proces asimilacije stranaca u domaću sredinu, ali je vjerojatno bilo i primjera obrnutog procesa. Zbog kroatiziranja mnogih imena, možemo zaklju- 
čiti da postoji jaka tendencija asimilacije. Obrtnici su bili prvi koji su uskočili zadovoljavati potrebe stanovništva nakon zabrane djelovanja cehova 1872. godine. Iz Adresara se vidi da su stanovnici mogli zadovoljiti osnovne potrebe za obrtničkim uslugama i u malim mjestima, a ne samo u gradu, koji je bio administrativni, kulturni, sudski, prosvjetni i gospodarski centar njihova područja; možda je upravo množina obrtnika uvjetovala da su Križevci lagano prošli kroz krizu nastalu ukidanjem njihova središta kao centralnog mjesta županije, te su se počeli razvijati snažnije kao turistički i industrijski te obrazovni centar nadoknađujući time gubitak administrativnog središta. Svakako je tu veliku ulogu odigrala križevačka Ratarnica, odnosno Gospodarsko učilište, koje je bilo magnet za privlačenje učenika u školu sa šireg područja. Dakako da kriza nije mimoišla ni obrtnike i trgovce u Križevcima. Borba za opstanak bila je vrlo teška i nemilosrdna, jer novčarstvo kao ni proizvodno-prodajno zadrugarstvo još nije bilo razvijeno, a uloga plemstva u gospodarstvu svedena je na djelatnost plemstva obitelji Kiepach, Šandora Fodroczija i grkokatoličkog biskupa Drohobeckog, koji je imao sjedište u Križevcima. Križevačko područje, nekoć kraj dobrog standarda, pokazuje zaostajanje u gradu, ali život izvan grada preuzima vodstvo u gospodarstvu, pa je obrtnika u Križevačkom kotaru bilo više nego u dva druga kotara obrađena u ovom radu.

\section{Obrtnici u trgovištu Đurđevac 1890. godine.}

Đurđevac nikada nije bio županijsko središte i nije imao mnogo svojeg vojnog plemstva, ali je stoljećima na granici prema Osmanlijama imao odlučujuću ulogu u borbama, sačuvavši i svoju prastaru utvrdu, koja je danas našla svoju muzejsko-galerijsku i ugostiteljsku namjenu. Ona je i danas poznata kao Stari grad i tu se svake godine održavaju igre, koje slikovito odražavaju kako su Đurđevčani zaustavili prodiranje osmanlijske vojske prema zapadu uvjerivši Osmanlije izbacivanjem pilića iz topova da mogu dugo izdržati opsadu. Taj je otpor bio među prvima nakon Mohačke bitke i Đurđevčani su očito bili posebni i svakako vrlo hrabri kao krajišnici. ${ }^{20}$ Vodstvo Varaždinskoga generalata taj je kraj tretiralo kao granicu prema Turcima, pa je tu život dugo bio nesiguran. Poslije Karlovačkog mira 1699. to je područje postalo izvorište krajišnika za ratove koje je Beč vodio po Europi. To se odrazilo na velikom broju palih krajišnika te su prošteništa Molve i Komarnica te druga posvećena Blaženoj Djevici Mariji kao Isusovoj majci bila uvijek dobro posjećena, a na njima su se uvijek skupljali obrtnici sa svojom robom, bili to medičarski ili korisni predmeti za poljopri-

20 Vesna PETROVIĆ-PEROKOVIĆ, Picokijada od ljeta do ljeta. Đurđevečki zbornik, 1996., Đurđevac, 1996, 109-121. 
vredno kućanstvo. Krajišnici s tog područja odlikovali su se hrabrošću, te su mnogi postigli i visoke vojne činove, kao Petar Preradović, rođen u Grabrovnici, koji je postao general. Zanimljivo je da Đurđevačka pukovnija nije imala svoje sjedište u Đurđevcu već u Bjelovaru, iako je u Đurđevcu bilo sagrađeno veliko vojno skladište koje je krajem 19. stoljeća Emanuel Braun pretvorio u parni mlin. I na Picokijadi, koja se održava svake godine u lipnju, izlažu obrtnici iz čitavog kraja svoje proizvode. Veliki slikar Ivan Lacković Croata iz Batinske ovjekovječio je prizore iz njihova života na svojim crtežima, kao i Mijo Kovačić iz Gornje Šume te Ivan Večenaj iz Prekodravlja. Iako Đurđevac nikada nije imao status komunitata, u njemu su se potkraj trajanja Vojne krajine naselili mnogi obrtnici Nijemci, pa je to ostavilo trag u nazivu alata.

Tablice 8 i 9 rađene su prema istom principu kao i one za Koprivnicu i Križevce.

Tablica 8. Cjelokupno obrtništvbo trgovišta Đurđevac i broj obrtnika u ostalom dijelu kotara te ukupno 1890. godine.*

\begin{tabular}{|l|l|l|l|l|}
\hline \multicolumn{1}{|c|}{ Vrst obrta } & \multicolumn{1}{|c|}{ Ime Obrtnika } & \multicolumn{3}{c|}{ Obrtnici } \\
Ostalo & \multicolumn{1}{c|}{ Ukupno } \\
\hline Bojadisari tkanina i dr. & Böhm Hinko & 1 & 1 & 2 \\
\hline Bačvari & $\begin{array}{l}\text { Baršić Franjo, } \\
\text { Domišljanović } \\
\text { Valent, Raptavi } \\
\text { Martin, Vukobradović Edo }\end{array}$ & 4 & 21 & 25 \\
\hline Bravari & $\begin{array}{l}\text { Kirin Gjuro, Šavor } \\
\text { Miroslav, Šegrc Anton, } \\
\text { Škripec Imbro }\end{array}$ & 4 & 8 & 12 \\
\hline Brijači & $\begin{array}{l}\text { Freibisch Matilda } \\
\text { Dimnjačari }\end{array}$ & 1 & - & 1 \\
\hline Gostioničari & Berdušek Franjo & 1 & - & 1 \\
\hline Klobučari - kapari & $\begin{array}{l}\text { Nöthig Ivan, Vukobradić } \\
\text { Edo }\end{array}$ & 2 & 3 & 5 \\
\hline Kolari & Dragšić Janko & 21 & 35 \\
\hline & $\begin{array}{l}\text { Dokuš Bolto, Dolenc Mio, } \\
\text { Gjörgji Stjepan, Hodalić } \\
\text { Ivo, Janči Marko, Kolar } \\
\text { Martin, Koren Mato, } \\
\text { Kovačić Ignac, Legradi } \\
\text { Roza, Martinčić Bolto, } \\
\text { Mirović Martin, Štefec } \\
\text { Mato, Štefoković Valent, } \\
\text { Zvonar Gjuro }\end{array}$ & 14 & 1 & 3 \\
\hline
\end{tabular}


Rad Hrvat. akad. znan. i umjet. Razred za druš. znan. 55=545(2021) : 31-102

\begin{tabular}{|c|c|c|c|c|}
\hline Ciglari & - & - & 1 & 1 \\
\hline Kovači & $\begin{array}{l}\text { Benta Josip, Gjörgji Petar, } \\
\text { Gjuroci Bolto, Hodalić } \\
\text { Mato, Koren Stjepan, } \\
\text { Kudumija Ivo, Lešćan } \\
\text { Janko, Lovrak Mio, Mašnin } \\
\text { Bolto, Pavlović Ivo, Peršić } \\
\text { Bolto, Petroško Adam, } \\
\text { Radošević Gjuro, Redjep } \\
\text { Stjepan, Singer Gejza, } \\
\text { Vinkoci Mato, Zlatec Joso }\end{array}$ & 17 & 50 & 67 \\
\hline Krčmari & $\begin{array}{l}\text { Domitrovć Mio, Gjurišević } \\
\text { Martin, Marenić Josip, } \\
\text { Mihinić Gjuro, Rakić } \\
\text { Gjuro, Trbuljak Josip }\end{array}$ & 6 & 49 & 55 \\
\hline Krojači & $\begin{array}{l}\text { Balatinec Luka, Ćikoša } \\
\text { N. udova, Damović } \\
\text { Marica, Franjo Stjepan, } \\
\text { Gjurišević Josip, Hanzl } \\
\text { Josip, Hrženjak Gustav, } \\
\text { Jadriev Mato, Kožar Barica, } \\
\text { Lauš Reze, Petrić Marta, } \\
\text { Pintar Martin, Redjep } \\
\text { Bara, Rozman Filip, Zidar } \\
\text { Stjepan, Zlatec Gjuro }\end{array}$ & 16 & 11 & 27 \\
\hline Ljekarnici & Brumec T. & 1 & 1 & 2 \\
\hline Lončari & $\begin{array}{l}\text { Bubnić Joso, Ognjenčević } \\
\text { Ivo, Vinkoci Mio }\end{array}$ & 3 & 14 & 17 \\
\hline Medičari i voštari & Mayer Mijo, Zajček Ludvig & 2 & 1 & 3 \\
\hline Mesari & $\begin{array}{l}\text { Barušić Mato, Maitz Mio, } \\
\text { Mohr Mirko, Nöthig Johan }\end{array}$ & 4 & 4 & 8 \\
\hline Mlinari & $\begin{array}{l}\text { Brebar Ana, Brebar Petar, } \\
\text { Bumlić Stjepan, Burulić } \\
\text { Janko, Fuček Mato, } \\
\text { Jakupčić Ivo, Janković } \\
\text { Stefo, Kubarski Martin, } \\
\text { Mandić Josip, Marić Mato, } \\
\text { Milvakšić Stevo, Starčević } \\
\text { Martin, Tomišen Mio }\end{array}$ & 13 & 75 & 88 \\
\hline Mlin parni & $\begin{array}{l}\text { Nöthig Eduard, Nöthig } \\
\text { Martin, Hirschler Šandor }\end{array}$ & 3 & 1 & 4 \\
\hline Opančari i čizmari & $\begin{array}{l}\text { Domitrović Mio, Gracinger } \\
\text { Joso }\end{array}$ & 2 & 1 & 3 \\
\hline
\end{tabular}


Rad Hrvat. akad. znan. i umjet. Razred za druš. znan. 55=545(2021) : 31-102

\begin{tabular}{|c|c|c|c|c|}
\hline Pekari & $\begin{array}{l}\text { Gottlieb Jakov, Mihinić } \\
\text { Gjuro, Nöthig Martin }\end{array}$ & 3 & 5 & 8 \\
\hline Poduzetnici & Brenner Ferdo & 1 & - & 1 \\
\hline Postolari & $\begin{array}{l}\text { Baknić Joso, Grabler Mio, } \\
\text { Janaček Franjo, Jurišić } \\
\text { Josip, Kolarević Tomo, } \\
\text { Kralj Nikola, Levak Mio, } \\
\text { Madjerek Jakob, Mrazek } \\
\text { Ivan, Odobašić Bolto, } \\
\text { Patačko Janko, Pavin Petar, } \\
\text { Pavunić Ivo, Pleško Stjepan, } \\
\text { Pourić Dragoljub, Prepelec } \\
\text { Simo, Šadek Gjuro, Šalvari } \\
\text { Mara, Sivjanović Gjuro, } \\
\text { Vitković Jakob }\end{array}$ & 20 & 28 & 48 \\
\hline Sedlari i remenari & $\begin{array}{l}\text { Gečević Stjepan, Sestrić } \\
\text { Slavoljub, Škrlec Mio }\end{array}$ & 3 & 1 & 4 \\
\hline Staklari & Jauk Martin & 1 & -- & 1 \\
\hline Stolari & $\begin{array}{l}\text { Crnčić Martin, Bakrač } \\
\text { Marko, Dokuš Stjepan, } \\
\text { Dumbović Mio, Jadan } \\
\text { Mato, Kobuli Ivan, Pavin } \\
\text { Josip, PogačnikValent, }{ }^{* *} \\
\text { Simonyi Blaž, Šante } \\
\text { Podravec Janko, Šeljert } \\
\text { Gjuro }\end{array}$ & 11 & 24 & 35 \\
\hline Țesari & Bricl Ante, Ivanuša Lovro & 2 & 1 & 3 \\
\hline Tkalci & Gudić Ivan, Tončić Gjuro & 2 & 1 & 3 \\
\hline Tokari & $\begin{array}{l}\text { Grumerac Ivan, Obranović } \\
\text { Ante }\end{array}$ & 2 & 3 & 5 \\
\hline Užari & Šugović Petar & 1 & 3 & 4 \\
\hline Zidari & Pameto Ivan, Vimer Andro & 2 & 5 & 7 \\
\hline Limari & - & - & 2 & 2 \\
\hline Slastičari & - & -- & 1 & 1 \\
\hline Octari & - &.- & 1 & 1 \\
\hline Ukupno & & 143 & 303 & 446 \\
\hline
\end{tabular}

* G, JUSTUS, L. STROHMAYER, Adresar obrtnog i poslovnog svieta u Hrvatskoj g. 1890, Zagreb, 1891., str. 80-214. ** Valent Pogačnik pradjed je Mire Kolar-Dimitrijević po očevoj strani. Podcrtana su ženska imena. 
Kao i kod drugih kotara, i ovdje se u tablici 8 , radi komparacije, donosi i broj obrtnika u Đurđevačkom kotaru, iskazan poimence u tablici 9; iznenađuje da je broj obrtnika u kotaru bio dvostruko veći nego u samom Đurđevcu, što je vjerojatno posljedica načina života u Đurđevačkoj pukovniji. Tu je krajišnik bio i vojnik i seljak, a vjerojatno i obrtnik, jer Đurđevac nije bio komunitet kao što su to bili Bjelovar, Glina i Petrinja, pa je prvo mjesto u kojem su do 1871. živjeli slobodni obrtnici bio Bjelovar, što i djeluje na to da đurđevačko područje gospodarski gravitira prema Bjelovaru, a ne toliko prema Koprivnici. No možda je to i posljedica prometne željezničke izoliranosti područja od Koprivnice do Kloštra, koje je područje tek 1911. uključeno u željezničku mrežu Hrvatske izgradnjom dosta loše pruge Koprivnica - Kloštar. Pritom je Kloštar bio vezan uz Bjelovar i Viroviticu, koja je bila vezana prugom uz Barč na mađarskoj strani, još prije nego što je sagrađen odvojak pruge Kloštar - Koprivnica 1911. godine. Veza Osijeka kao sjedišta Virovitičke županije s Bjelovarom kao sjedištem Bjelovarsko-križevačke županije bila je čvršća nego ona Osijeka s Koprivnicom i očito su se vlastodršci trudili da se ne uspostave čvršće veze svih krajeva uz desnu obalu Drave. Na području Đurđevačkoga kotara nije bilo veleposjednika izuzev Đurđevačke imovne općine, a krajiške zadruge već su se podijelile, pa su obrti isključivo u rukama pojedinaca, što je otežalo proizvodnju i prodaju, te su mnoge struke slabije razvijene od onih na koprivničkom i križevačkom području. To se s izgradnjom pruge Kloštar - Koprivnica počinje mijenjati.

Radom obrtnika zadovoljavale su se potrebe domaćeg stanovništva, koje se uglavnom bavilo poljoprivredom i stočarstvom. Najviše ima kolara, kovača, stolara, postolara, dakle onih obrtnika koji su bili neminovno potrebni za svakodnevni život stanovništva i koje se potrebe nisu mogle podmiriti radom u kućnoj radinosti. Prevladavaju kovači i kolari, dakle obrtnici koji vode brigu o kolima, bez kojih ne bi bilo prometa, a ni sajmova i trgovine. Usporedba imena obrtnika s vlasnicima čestica u Đurđevcu 1868. godine ukazuje da su mnogi obrtnici bili i vlasnici katastarskih čestica, tj. da su imali svoje kuće i svoju zemlju. ${ }^{21}$ Zapaža se velik broj mlinara, pri čemu se vjerojatno radi o mlinarima koji su držali u pogonu brojne vodenice, dok su svega tri mlina na parni pogon, i to dva u Đurđevcu i jedan u Pitomači; benzinskih mlinova i motora na upojni plin još nema, a nisu bili ni potrebni jer je cijelo područje prošarano potocima raznih veličina koji su kasnije usmjereni u veće kanale. Vodeničari su bili upošljivi i u parnim mlinovima kada su ovi počeli istiskivati vodenice. ${ }^{22}$ Osjeća se dolazak brojnih Židova iz

$21 \quad$ N. CIK, Izvođenje i realizacija, str. 73-76.

22 G. JUSTUS, L. STROHMAYER, Adresar obrtnog i poslovnog svieta u Hrvatskoj g. 1890, Zagreb, 1891. 80-214. 
Mađarske ili štajerskog dijela Austrije, koji potiskuju obrtnike Nijemce, kojih je u Đurđevcu, barem sudeći po prezimenima, bilo dosta. Zbog blizine Mađarske, u to vrijeme bilo je i dosta obrtnika s mađarskim prezimenima.

Devet žena u trgovištu Đurđevac i osam u kotaru daju dojam da su žene na tom području bile aktivnije u obrtu nego u druga dva kotara.

U trgovištu su žene predvodnice nekih obrta. Tako je Matilda Freibisch vodila brijačku radnju, a Roza Legradi imala je kolarsku radnju. Osobito su brojne krojačice: N. Čikota, udova, Marica Damović, Barica Kožar, Marta Petrić i Bara Redjep. Ana Brebar bila je mesarica, a Mara Šalvari postolarica.

\section{Obrtnici u Đurđevačkom kotaru bez trgovišta Đurđevac 1890. godine}

Na području kotara obrtnici su bili brojni i seljaci su mogli podmiriti gotovo sve svoje potrebe kod svojih obrtnika, koji su često bili i poljoprivrednici. No struka je manje nego u druga dva kotara.

Tablica 9. Obrtništvo u Đurđevačkom kotaru 1891. godine bez Đurđevca*

\begin{tabular}{|l|l|l|l|l|}
\hline \multicolumn{1}{|c|}{ Vrsta obrta } & \multicolumn{1}{|c|}{$\begin{array}{c}\text { Mjesto na području } \\
\text { kotara }\end{array}$} & \multicolumn{1}{|c|}{ Pošta } & \multicolumn{1}{|c|}{ Ime obrtnika } & \multicolumn{1}{|c|}{ Broj } \\
\hline Bačvari & Virje** & Virje & $\begin{array}{l}\text { Fogl Mio, Haljinko Stevo, } \\
\text { Kopas Gjuro, Pintar Gjuro, } \\
\text { Pintar M., Pintar Stevo }\end{array}$ & 6 \\
\hline & Ferdinandovac & Đurđevac & $\begin{array}{l}\text { Franković Šandor, Oberhofer } \\
\text { Johan, Slaviček Andro }\end{array}$ & 3 \\
\hline & Pitomača & Đurđevac & $\begin{array}{l}\text { Balatinec Bara, Horvat Štefo, } \\
\text { Smigavec Đuro }\end{array}$ & 3 \\
\hline & Ždala & Pitomača & $\begin{array}{l}\text { Karoli Gabriel, Karoli Martin, } \\
\text { Rosenberg Ante, Perko } \\
\text { Gjuro, Sokol Mijo }\end{array}$ & 5 \\
\hline Bravari & Virje & Virje & $\begin{array}{l}\text { Lanhart Joso, Pek Joso, } \\
\text { Vučetić Franjo }\end{array}$ & 3 \\
\hline & Ferdinandovac & Virje & $\begin{array}{l}\text { Brodarić Luka, Pokec Stevo, } \\
\text { Šǒ́ pl. Andro, Tkalčec Joso, } \\
\text { Varga Joso }\end{array}$ & 5 \\
\hline & Molve & Virje & Augustić Andro & 1 \\
\hline
\end{tabular}

++:: Vladimir MIHOLEK, Đurđevački mlinovi na parni i ostale vrsta pogona s kraja 19. i prve polovice 20. stoljeća, Podravina, Vol. 14, br. 24, 81-88; Mira KOLAR-DIMITRIJEVIĆ, Elizabeta WAGNER, Mlinari i vodeničari na području varaždinskog, ludbreškog, koprivničkog i đurđevačkog kotara 1891. godine, Ekonomska i ekohistorija, vol. XV, br. 15, Zagreb, 2019., 125-138. 
Rad Hrvat. akad. znan. i umjet. Razred za druš. znan. 55=545(2021) : 31-102

Mira Kolar-Dimitrijević: Popis obrtnika na području današnje Koprivničko-križevačke županije 1890. godine

\begin{tabular}{|c|c|c|c|c|}
\hline & Pitomača & Pitomača & Kaić Ferdo & 1 \\
\hline Ciglari & Ferdinandovac & Đurđevac & Digniste Vjekoslav & 1 \\
\hline Čizmari & Pitomača & Pitomača & Pavleković Jovo & 1 \\
\hline \multirow[t]{2}{*}{ Gostioničari } & Virje & Virje & Avirović Jovo, Potai Rudolf & 2 \\
\hline & Ferdinandovac & Đurđevac & Toth Josip & 1 \\
\hline Klobučari & Virje & Virje & $\begin{array}{l}\text { Ljubić Andrija, Vipovec } \\
\text { Nikola }\end{array}$ & 2 \\
\hline \multirow[t]{7}{*}{ Kolari } & Virje & Virje & $\begin{array}{l}\text { Bešenić Stevo, Bešenić Stevo } \\
\text { ml., Kucelj Martin, Sabolić } \\
\text { Andro, Sinković Petar } \\
\text { U Molvama Medjurečan Mio } \\
\text { i Gjuro Stankir }\end{array}$ & 7 \\
\hline & Ferdinandovac & Đurđevac & $\begin{array}{l}\text { Barberić Stjepan, Fuk Mio, } \\
\text { Jusak Joso, Puhač Martin }\end{array}$ & 4 \\
\hline & Kalinovac & Đurđevac & Miklić Joso & 1 \\
\hline & Kozarevac & Pitomača & Szanto Gjuro & 1 \\
\hline & Pitomača & Pitomača & $\begin{array}{l}\text { Hierćak Dominik, } \\
\text { Komletinski Ivo, Šohinger } \\
\text { Petar, Šopinger Valent, } \\
\text { Vlašić Mato }\end{array}$ & 5 \\
\hline & Sesvete Kloštar & Pitomača & Gluhak Stevo, Horvat Ivo & 2 \\
\hline & Ždala & Virje & Lovašin Mato & 1 \\
\hline \multirow[t]{8}{*}{ Kovači } & Virje & Virje & $\begin{array}{l}\text { Avirović J., Baruškin Mato, } \\
\text { Hrženjak Franjo, Hrženjak } \\
\text { Martin, Kemenović Andro, } \\
\text { Lončar Bolto, Pintar Joso, } \\
\text { Pisačić Mio, Plemenčić } \\
\text { Mato, Šklebar Jakob, } \\
\text { Turjanić Mio, Venzlin Mato }\end{array}$ & 12 \\
\hline & Čepelovec & Đurđevac & Pleško Martin & 1 \\
\hline & Črešnjevica Velika & Pitomača & Benko Ivan, Varga Josip & 2 \\
\hline & Ferdinandovac & Đurđevac & $\begin{array}{l}\text { Dobrostol Petar, Fekete } \\
\text { Josip, Molnavec Ante, } \\
\text { Težaški Stjepan }\end{array}$ & 4 \\
\hline & Kalinovac & Đurđevac & $\begin{array}{l}\text { Bogdan Gjuro, Jošak Ivo, } \\
\text { Pavišin Tomo }\end{array}$ & 3 \\
\hline & Katalena Sirova & Đurđevac & Mali Bolto & 1 \\
\hline & Kladare & Pitomača & Čikvar Mato, Pintarić Jakob & 2 \\
\hline & Otrovanec & Pitomača & Vitković Ante & 1 \\
\hline
\end{tabular}


Rad Hrvat. akad. znan. i umjet. Razred za druš. znan. 55=545(2021) : 31-102

Mira Kolar-Dimitrijević: Popis obrtnika na području današnje Koprivničko-križevačke županije 1890. godine

\begin{tabular}{|c|c|c|c|c|}
\hline & Pitomača & Pitomača & $\begin{array}{l}\text { Hesovja Štef, Kraljiček } \\
\text { Gjuro, Majstor Ivo, Malčec } \\
\text { Petar, Metelko Ante, Pavlić } \\
\text { Fran, Pavlić Stjepan }\end{array}$ & 7 \\
\hline & Sedlarica & Pitomača & Spitek Ivo, Srmiček Marko & 2 \\
\hline & Sesvete -Kloštar & Pitomača & $\begin{array}{l}\text { Habianić Fran, Haiduković } \\
\text { Stjepan, Hangl Joso, Pintarek } \\
\text { Mato }\end{array}$ & 4 \\
\hline & Siščani & Pitomača & $\begin{array}{l}\text { Bertak Luka, Golubić Ivan, } \\
\text { Grujević Mato }\end{array}$ & 3 \\
\hline & Šemovec & Virje & $\begin{array}{l}\text { Habek Gjuro, Posavec Bolto, } \\
\text { Vrabec Štefan }\end{array}$ & 3 \\
\hline & Ždala & Virje & $\begin{array}{l}\text { Hongl Joso, Kovač Stevo, } \\
\text { Novogradec Imbro, Pavečić } \\
\text { zadruga, Volarić Ferko }\end{array}$ & 5 \\
\hline \multirow[t]{14}{*}{ Krčmari } & Virje & Virje & $\begin{array}{l}\text { Bobinac Janko, Kočilović } \\
\text { Atanas, Muhvić Antun, } \\
\text { Pauhović Ludvig, Schleyer } \\
\text { Pavao, Stauber Jakob, Weiss } \\
\text { Albert }\end{array}$ & 7 \\
\hline & Budančevica & Pitomača & Korparić Joso & 1 \\
\hline & Bukovje Gornje & Virje & Domšić Juraj & 1 \\
\hline & Čepelovac & Đurđevac & Pavlešić Mirko, Prelec Tomo & 2 \\
\hline & Ćrešnjevica mala & Pitomača & $\begin{array}{l}\text { Breković Amalija, Gjurinović } \\
\text { Juraj }\end{array}$ & 2 \\
\hline & Črešnjevica velika & Pitomača & Sklebak Fran & 1 \\
\hline & Ferdinandovac & Đurđevac & $\begin{array}{l}\text { Hervoić Vojtjeh, Krakaner } \\
\text { Josiip, Krakaner Ladislav, } \\
\text { Vürzberger Roza }\end{array}$ & 4 \\
\hline & Grabrovnica & Pitomača & Gjurinović Juro & 1 \\
\hline & Kalinovac & Đurđevac & Švedek Stjjepan & 1 \\
\hline & Katalena Sirova & Đurđevac & Tomašec Bolfo & 1 \\
\hline & Kloštar & Pitomača & $\begin{array}{l}\text { Gašparić Joso, Joković Gjuro, } \\
\text { Korparić Josip, Stohr Fran, } \\
\text { Stohlc Edo, Vinkler Ljudevit }\end{array}$ & 6 \\
\hline & Kozarevac & Pitomača & Prager Josip, Kovačević Ivan & 2 \\
\hline & Mičetinac & Đurđevac & Mesar Josip & 1 \\
\hline & Molve & Virje & $\begin{array}{l}\text { Hiršler Mozes, Pevalek } \\
\text { Franjo, Peršić Martin, Tomac } \\
\text { Gjuro }\end{array}$ & 4 \\
\hline
\end{tabular}


Rad Hrvat. akad. znan. i umjet. Razred za druš. znan. 55=545(2021) : 31-102

Mira Kolar-Dimitrijević: Popis obrtnika na području današnje Koprivničko-križevačke županije 1890. godine

\begin{tabular}{|c|c|c|c|c|}
\hline & Otrovanec & Pitomača & Sesvećan Ante & 1 \\
\hline & Pitomača & Pitomača & $\begin{array}{l}\text { Brenner Ferdo, Götz } \\
\text { Dragutin, Gjurgjević Gjuro, } \\
\text { Gjurgjević Stevo }\end{array}$ & 4 \\
\hline & Prugovac & Pitomača & Schreiber Jakov & 1 \\
\hline & Sedlarica & Pitomača & $\begin{array}{l}\text { Kostanjević Gjuro, } \\
\text { Torbašinović Tomo }\end{array}$ & 2 \\
\hline & Sesvete - Kloštar & Pitomača & Mesar Josip & 1 \\
\hline & Šemovec & Virje & $\begin{array}{l}\text { Barac Tomo, Ivančak Franjo, } \\
\text { Madjer Ivan }\end{array}$ & 3 \\
\hline & Ždala & Virje & Pichler A., Pichler David & 2 \\
\hline Krojači & Virje & Virje & $\begin{array}{l}\text { Cilinger Josip, Fišer Josip, } \\
\text { Gottal Ferdo, Hrženjak } \\
\text { Benedikt, Plasek Tomo, } \\
\text { Švarc Simo }\end{array}$ & 6 \\
\hline & Budrovac & Đurđevac & Cuklaš Mara, Penzar Mio & 2 \\
\hline & Pitomača & Pitomača & Fanta Blaž, Farber Ivan & 2 \\
\hline & Sesvete - Kloštar & Pitomača & Fabianec Mato & 1 \\
\hline Limari & Virje & Virje & Cilinger Vid, Kem Bernhard & 2 \\
\hline Ljekarnici & Virje & Virje & Koszalek Emil & 1 \\
\hline Lončari & Virje & Virje & $\begin{array}{l}\text { Čorba Jakob, Dakarić Valent, } \\
\text { Fogl Franjo }\end{array}$ & 3 \\
\hline & Čepelovac & Đurđevac & Fuček Janko & 1 \\
\hline & Ferdinandovac & Đurđevac & Hervoić Vojtjeh & 1 \\
\hline & Kalinovac & Đurđevac & $\begin{array}{l}\text { Crok Martin, Golub Martin, } \\
\text { Knežić Mate }\end{array}$ & 3 \\
\hline & Kladare & Pitomača & Sobota Pavao & 1 \\
\hline & Kozarevac & Pitomača & Karas Tomo & 1 \\
\hline & Pitomača & Pitomača & $\begin{array}{l}\text { Bomec Mato, Saić Andro, } \\
\text { Sobota zadruga }\end{array}$ & 3 \\
\hline & Šemovec & Virje & Vlahović Stevo & 1 \\
\hline Medičari & Virje & Virje & Spilek Petar & 1 \\
\hline Mesari & Virje & Virje & Weiss Albert & 1 \\
\hline & Kloštar & Pitomača & Stohr Fran & 1 \\
\hline & Pitomača & Pitomača & $\begin{array}{l}\text { Gjorgjević Gjuro., Gjipalo } \\
\text { Andro u Budančevici }\end{array}$ & 2 \\
\hline
\end{tabular}


Rad Hrvat. akad. znan. i umjet. Razred za druš. znan. 55=545(2021) : 31-102

\begin{tabular}{|c|c|c|c|c|}
\hline Mlinari & Virje & Virje & $\begin{array}{l}\text { Dolenc Josip, Hapovel } \\
\text { Lovro, Imrek Gjuro, } \\
\text { Janković Stevo, Juranić Pero, } \\
\text { Kemenović Franjo }\end{array}$ & 6 \\
\hline & Budrovac & Đurđevac & $\begin{array}{l}\text { Labinac Bolto, Markov } \\
\text { Franjo, Mihalić Nata, Stankić } \\
\text { Nata }\end{array}$ & 4 \\
\hline & Bukovje gornje & Virje & $\begin{array}{l}\text { Mihalić Pero, Radinović } \\
\text { Janko, Radinović Mio }\end{array}$ & 3 \\
\hline & Čepelovac & Đurđevac & Koprec Simon, Renlia Mato & 2 \\
\hline & Črešnjevica velika & Pitomača & $\begin{array}{l}\text { Kapan Pavao, Stanić Leontin, } \\
\text { Utješenović Stjepan, } \\
\text { Vinkovec Mijo, Vučković } \\
\text { Jovan }\end{array}$ & 5 \\
\hline & Ferdinandovac & Đurđevac & $\begin{array}{l}\text { Čordašev Josip, Hervoić } \\
\text { Franjo, }{ }^{* * *} \text { Lončar Adam, } \\
\text { Štimac Ante, Vučeta Andro }\end{array}$ & 5 \\
\hline & Kalinovac & Đurđevac & $\begin{array}{l}\text { Dugelja Stjepan, Lobrta } \\
\text { Gjuro, Mihatović Joso, } \\
\text { Miklić Janko, Muha Mio, } \\
\text { Pantelić Mato, Švedek Mato, } \\
\text { Vucikuja Ivo }\end{array}$ & 8 \\
\hline & Katalena sirova & Đurđevac & $\begin{array}{l}\text { Horvat Joso, Krapec Gjuro, } \\
\text { Lakrec Jakob, Lovrak Martin, } \\
\text { Mihaljević Joso, Osman } \\
\text { Ivo, Schwarz Mavro, Serbić } \\
\text { Stjepan }\end{array}$ & 8 \\
\hline & Kozarevac & Pitomača & Romaj Franjo, Santo Gjuro & 2 \\
\hline & Molve & Virje & $\begin{array}{l}\text { Cenkovčan Stjepan, Hontić } \\
\text { Gjuro, Ivančan Franjo, } \\
\text { Ivančan Mio, Kovačić Gjuro, } \\
\text { Krznarić Mato, Lončar Mio, } \\
\text { Nakitanac Gjuro, Popec } \\
\text { Bolto, Sabolek Franjo, Žufika } \\
\text { Martin }\end{array}$ & 11 \\
\hline & Otrovanec & Pitomača & Kalenik Joso & 1 \\
\hline & Pitomača & Pitomača & $\begin{array}{l}\text { Bedeković Mijo, Desežić } \\
\text { Bartol, Gjurgjević Gjuro, } \\
\text { Kapan Gjuro, Maković } \\
\text { Gjuro, Nemet Josip, } \\
\text { Sesvečan Imbro, Šabarić } \\
\text { Gjuro }\end{array}$ & 8 \\
\hline
\end{tabular}


Rad Hrvat. akad. znan. i umjet. Razred za druš. znan. 55=545(2021) : 31-102

Mira Kolar-Dimitrijević: Popis obrtnika na području današnje Koprivničko-križevačke županije 1890. godine

\begin{tabular}{|c|c|c|c|c|}
\hline & Sedlarica & Pitomača & $\begin{array}{l}\text { Dobri Ferenc, Korač } \\
\text { Gjuro, Marešić Martin, } \\
\text { TorbašinovićTomo }\end{array}$ & 4 \\
\hline & Sv. Ana - Virje & Virje & Križan Andro, Škunja Marko & 2 \\
\hline & Šemovec & Virje & $\begin{array}{l}\text { Hinijet Martin, Vinković } \\
\text { Bolto, Vuskres Valent }\end{array}$ & 3 \\
\hline & Ždala & Virje & Kolarić Mio, Špoljar Gjuro & 2 \\
\hline Octara & Virje & Virje & Mikulčić Dragutin & 1 \\
\hline \multirow[t]{6}{*}{ Opančari } & Virje & Virje & $\begin{array}{l}\text { Avirović Šandor, Babec } \\
\text { Stjepan, Kopljarević Gjuro, } \\
\text { Kovač Mara,Matoničkin } \\
\text { Martin, Sabolić Stjepan }\end{array}$ & 6 \\
\hline & Budrovec & Đurđevac & Flamati Ivan & 1 \\
\hline & Ferdinandovac & Đurđevac & Havagović Andro & 1 \\
\hline & Kalinovac & Đurđevac & Švedek Mato, Zvonar Mio & 2 \\
\hline & Pitomača & Pitomača & $\begin{array}{l}\text { Ciglec Josip, Korporić Mato, } \\
\text { Pandurić Mato }\end{array}$ & 3 \\
\hline & Šemovec & Virje & Kopas Bolto & 1 \\
\hline Parni mlinovi & Kloštar & Pitomača & Pušik Martin & 1 \\
\hline \multirow[t]{3}{*}{ Pekari } & Virje & Virje & $\begin{array}{l}\text { Avirović Gjuro, Gottlieb } \\
\text { Josip, Sabolić Stjepan }\end{array}$ & 3 \\
\hline & Molve & Virje & Peršić Martin & 1 \\
\hline & Pitomača & Pitomača & Götz Dragutin, Zsisel Šandor & 2 \\
\hline \multirow[t]{6}{*}{ Postolari } & Virje & Virje & $\begin{array}{l}\text { Benkek Mato, Bezjak Jakob, } \\
\text { Fundak Tomo, Grahovac } \\
\text { Petar, Jakulin Mio, Jakupec } \\
\text { R., Kovač Gjuro, Kovač } \\
\text { Stjepan }\end{array}$ & 8 \\
\hline & Ferdinandovac & Đurđevac & $\begin{array}{l}\text { Barusa Josip, Kolar Stjepan, } \\
\text { Martinković Josip }\end{array}$ & 3 \\
\hline & Kalinovac & Đurđevac & $\begin{array}{l}\text { Dautance Mate, Lončar } \\
\text { Šandor }\end{array}$ & 2 \\
\hline & Pitomača & Pitomača & $\begin{array}{l}\text { Beker Josip, Čikvar Ivan, } \\
\text { Fanto Mato, Fanto Martin, } \\
\text { Kabun Gjuro, Komletinski } \\
\text { Jakob, Kovač Blaž, Mesarić } \\
\text { Pavao, Perhot Gjuro, Prinke } \\
\text { Šandor, Vunak Joso }\end{array}$ & 11 \\
\hline & Šemovec & Virje & $\begin{array}{l}\text { Cvetković M., Horvat Franjo, } \\
\text { Prepelec Stjrpsn }\end{array}$ & 3 \\
\hline & Ždala & Virje & Grčić Antun & 1 \\
\hline
\end{tabular}


Rad Hrvat. akad. znan. i umjet. Razred za druš. znan. 55=545(2021) : 31-102

Mira Kolar-Dimitrijević: Popis obrtnika na području današnje Koprivničko-križevačke županije 1890. godine

\begin{tabular}{|c|c|c|c|c|}
\hline $\begin{array}{l}\text { Sedlari i } \\
\text { remenari }\end{array}$ & Pitomača & Pitomača & Sako Šandor & 1 \\
\hline Slastičari & Virje & Virje & Špilek Petar & 1 \\
\hline \multirow[t]{8}{*}{ Stolari } & Virje & Virje & $\begin{array}{l}\text { Erhatić Josip, Habrun Ferdo, } \\
\text { Jerešinović Antun, Lacković } \\
\text { Martin, Petričec Josip, Veseli } \\
\text { Antun ml., Veseli Antun st. }\end{array}$ & 7 \\
\hline & Čepelovec & Đurđevac & Melinčević Josip, & 1 \\
\hline & Ferdinandovac & Đurđevac & $\begin{array}{l}\text { Gjöri Luka, Rujnić Andro, } \\
\text { Rujnić Ivan, Rupnik Ivan }\end{array}$ & 4 \\
\hline & Kalinovac & Đurđevac & $\begin{array}{l}\text { Karlovčan Bolto, Kovačev } \\
\text { Joso, Metelko Joso }\end{array}$ & 3 \\
\hline & Molve & Virje & Balogović Mato, Kukec Petar & 2 \\
\hline & Otrovanec & Pitomača & Vitković Franjo & 1 \\
\hline & Pitomača & Pitomača & $\begin{array}{l}\text { Bazant Ivan, Hernjec Simo, } \\
\text { Kovačić Ivo, Tarij Gavro }\end{array}$ & 4 \\
\hline & Sesvete - Kloštar & Pitomača & Škripac Franjo & 1 \\
\hline Tesari & Virje & Virje & Lukić Martin & 1 \\
\hline Tkalci & Virje & Virje & Lambek Martin & 1 \\
\hline \multirow[t]{2}{*}{ Tokari } & Virje & Virje & Matoničkin Mio, Pintar Joso & 2 \\
\hline & Pitomača & Pitomača & Papet Ignac & 1 \\
\hline \multirow[t]{2}{*}{ Užari } & Virje & Virje & $\begin{array}{l}\text { Lukanec Mato, Mihalić } \\
\text { Antun }\end{array}$ & 2 \\
\hline & Pitomača & Pitomača & $\begin{array}{l}\text { Funta Mijo, Holina Ivan, } \\
\text { Katulić Mijo }\end{array}$ & 3 \\
\hline \multirow[t]{4}{*}{ Zidari } & Virje & Virje & $\begin{array}{l}\text { Fantoni Eduard, Mikelček } \\
\text { Ivan }\end{array}$ & 2 \\
\hline & Čepelovec & Đurđevac & Anaušak Mato & 1 \\
\hline & Kalinovac & Đurđevac & Jambrović & 1 \\
\hline & Molve & Virje & $\begin{array}{l}\text { Schunko Hinko, Kopričanec } \\
\text { Imbro, Kopričanec Mijo, } \\
\text { Lucek Mato, Šadek Dragutin }\end{array}$ & 5 \\
\hline $\begin{array}{l}\text { Bojadisar } \\
\text { tkanina }\end{array}$ & Virje & Virje & $\begin{array}{l}\text { Kohn Albert (poslovođa J. } \\
\text { Hofman) }\end{array}$ & 1 \\
\hline Ukupno & & & & 303 \\
\hline
\end{tabular}

*G, JUSTUS, L. STROHMAYER, Adresar obrtnog i poslovnog svieta u Hrvatskoj g. 1890, Zagreb, 1891., str. 80-214. Podcrtana su ženska imena.

**Virje je trgovište kao i Đurđevac i zbog toga je označeno debljim slovima. 
Đurđevac je bilo sjedište kotara, ali trgovište Virje nije zaostajalo po broju obrtnika za Đurđevcem, koji je, barem nominalno, bio do spajanja Vojne krajine s Banskom Hrvatskom sjedište Đurđevačke pukovnije u vrijeme Vojne krajine, kao što su Križevci bili nominalno sjedište Križevačke pukovnije, iako se, zbog praktičnih razloga, objema županijama upravljalo iz Bjelovara. Bjelovar je bio i središte 1872. osnovane Bjelovarske županije te je 1886. spojen s Križevačkom županijom. Satnije su bile manjeg značaja, ali su još dugo nastojale dobiti neke upravne funkcije, a vlada je nastojala da se funkcije podijele, te je Novigrad Podravski postao izborni kotar, iako nije bio najveće mjesto na tom području i iako nije pripadao Đurđevačkom kotaru. No Đurđevac je već 1886. dobio kotarski sud, što mu je davalo veliki značaj. Ukinućem Varaždinskoga generalata i razvojačenjem to je područje pripojeno Banskoj Hrvatskoj, a vlada je na temelju političke podobnosti, odnosno aktivnosti ilirca Ferde Rusana, odlučila da Đurđevac bude kotarsko središte, s time da je Virje potpalo pod Đurđevac, a Novigrad je pripao Koprivničkom kotaru. Ipak, tragovi njegove važnosti u prošlosti dugo su se zadržali. Tako je Virje imalo ljekarnu, iako nije bilo središte kotara, te brojne obrtnike i trgovce. (Kako bismo upozorili na važnost Virja na obrtničkom polju, u tablici 9 Virje je uvijek pisano masnim slovima.).

U kotaru bez trgovišta djelovala je kao bačvarka Bara Balatinec. Krčme su držale Amalija Breković i Roza Vürzberger. Krojačku radnju u Budrovcu vodila je Mara Cuklaš. Mlinarice su Nata Mihalić i Nata Stankić u Budrovcu. Opančarsku radnju u Virju drži Mara Kovač.

Ni u trgovištu Đurđevac, ali ni u kotaru nije bilo plemstva koje bi imalo neki zemljišni posjed, iako su se neki članovi nižeg plemstva, armalista, dobivenog za dugogodišnje služenje u vojsci, prilagodili vremenu. Tako je Andro pl. Šoš držao u Virju bravarsku radnju, a obitelj Šoš stanovala je u velikoj vojnoj zgradi još i za vrijeme Drugoga svjetskog rata baveći se trgovinom tekstila i obradom svojeg vinograda. No još su se zadržale neke krajiške zadruge, pa je zadruga Pavčec u Ždali držala kovačnicu, a zadruga Sobota u Pitomači lončariju. Izostanak većih posjeda, izuzev državnih šuma, nije zadovoljio neke agilne pojedince, bivše krajišnike, te je Martin Pušika u Kloštru sagradio mali parni mlin, a u Đurđevcu je parni mlin osnovao Eduard Nöthig iz Ferdinandovca, dok se Martin Nöthig bavio pekarstvom. Budući da su šume uz Dravu bile uglavnom posječene, Židovi koji su se počeli doseljavati iz Mađarske shvatili su mogućnost Podravine da proizvodi žito, te su, privučeni mogućnošću dodatne zarade, ali i znanjem o parnim mlinovima koje su osmislili Mađari, započeli podizati velik broj mlinova. Pionir u tom poslu bio je Šandor Hirshler, koji je sagradio prvi parni mlin u Đurđevcu. 
Budući da je područje Đurđevca do 1911. bilo bez željeznice, roba se još uvijek dopremala cestom iz Bjelovara ili Dravom, ali je plovidba, zbog onečišćenja, bila vrlo rizična. Obrtnici su imali na raspolaganju samo pošte u Đurđevcu, Virju i Pitomači.

\section{Brojno stanje i etničko porijeklo obrtnika u sva tri kotara 1890. godine.}

Već je rečeno da su obrtnici u ovom radu svrstani u struke kako ih je vodila Trgovačko-obrtnička komora u Zagrebu. Ta struktura zadržala se dugo. Tek 1931. odvojene su Trgovačka i Industrijska komora od Obrtničke, a 1938. formirana je i posebna Komora za ugostiteljstvo. Kako se struke ne bi spajale, u tablici 10 navedeni su obrtnici onako kako su tiskani u Adresaru. Nema spajanja, ali ni razdvajanja. Posebno su iskazani krčmari, gostioničari i ugostitelji, zatim postolari, čizmari i opančari, pa tesari, stolari i tokari te razne vrste obrtnika koji su se bavili obradom tekstila ili metaloprerađivačkom djelatnošću.

Iz Adresara saznajemo i da su se mnogi obrtnici bavili raznim poslovima u više struka, a kod krčmara nalazimo čest slučaj da je uz krčmu ili gostionicu bila vezana trgovina ili mesnica.

Problem čine i tvornice. Iz malog broja tvornica, osobito onih koje su se služile parnim strojem, vidimo da je navedeno područje bilo na početku industrijalizacije te da su ciglane i ciglari te crepari bili malobrojni jer su po selima još uvijek prevladavale drvene kuće prekrivene slamom. Mlinovi su većinom bili vodenice građene uz potoke ili su to bili kašikari, a gotovo svako selo imalo je svoj mali mlin. Tek nekoliko mlinova imalo je kombinirani vodeni i parni pogon. Pilana uopće nije bilo, što ukazuje na to da su do tada - što se osobito odnosi na šume u vlasništvu države - posječene zrele šume i eksportirane splavima kao drvna sirovina u tvornice u Osijeku Dravom ili željeznicom u Zagreb ili u srednju Europu, gdje je potreba za drvenim pragovima kod gradnje željeznica bila ogromna. ${ }^{23}$ Zbog ograničenosti prostora, $\mathrm{u}$ ovom radu nije moguće dati šira objašnjenja, ali ih spominju mnogi autori.

23 Osobito je bila traženo drvo hrasta lužnjaka. Tako je još 1911. do virovske željezničke stanice dopremano drvo iz okolice Drave uskotračnom željeznicom i onda otpremano dalje do cilja. U taj posao bila je svakako uključena i donjodubravska firma Ujlaki-Hirschler (D. FELETAR, Iz povijesti splavarstva na Dravi, Meridijani, Donja Dubrava, 2019., 59). Sječa šuma u zadnjem desetljeću prije ukinuća Vojne krajine donijela je mnogim krajišnicima, ali i državnim šumarijama, kapital koji se onda mogao ulagati u industriju. Neki su u tome bili sretne ruke, no neki i nisu. Matija Peršić, mlinar iz Virja, kupio je „venecianer“, tj. okomitu pilu od propale tvrtke Hirschler misleći da će mu to omogućiti bolje poslovanje, jer mljevenje žita kraj male površine, ali i zbog konkurencije vodenica, nije omogućavalo poslovanje mlina čitave godine. Osim toga u Virju je, u Mitrovačkoj ulici, radila u međuratnom razdoblju i pilana Steidl. 
No svi podaci upućuju na zaključak da je područje današnje Koprivničkokriževačke županije bilo 1890. još uvijek ruralno i da je više obrtnika živjelo na selima nego u kotarskim sjedištima. To je obrtništvo gotovo potpuno zadovoljavalo potrebe stanovništva na selu, pa su najbrojniji oni obrtnici koji su bili potrebni seljaku, a to su kovači, kolari, stolari i obučari. Dok se u gradovima moglo naći obrtnika više vrsta, selo je bilo siromašno u izboru te su najbrojniji bili krčmari, jer su to bila mjesta informiranja, dogovaranja i političkih prepucavanja - upravo je kraj 19. stoljeća, uslijed prometnog otvaranja, bio razdoblje žestokih političkih borbi između pravaša i mađarona, a onda je politički život oživio i djelovanjem braće Radić, njihovim ukazivanjem na činjenicu da je seljaštvo najbrojniji društveni sloj u Hrvatskoj koji ima pravo biti gospodar u svojoj državi. ${ }^{24}$

Struktura obrtništva pokazuje da nekih obrtnika koje bismo u većem broju očekivali s obzirom na strukturu gospodarstva nije bilo. U kraju gdje su stočarstvo i svinjarstvo bili dominantna grana nema tako nijedne kožare, iako su bili brojni i postolari, i opančari, i remenari, i sedlari. Svinjokolje se obavljaju po privatnim kućama, pa je takvo nekontrolirano klanje često bilo uzrok pošasti koje su često dovodile do zabrane izvoza mesa, što je činilo poljoprivrednicima veliku štetu. Sve što se moglo obavljalo se u domaćinstvima. U cijelom su kraju, usprkos čestim požarima, poslovala samo četiri dimnjačara, i to u Koprivnici i Križevcima, dok ih izvan tih gradova uopće nije bilo. Usprkos nekad poznatoj Magdalenićevoj manufakturi, pećara ima malo, pa pretpostavljamo da su se već koristile željezne peći, odnosno da se kuhalo na kuhinjskom štednjaku koji su seljaci sami gradili, a koji je i zagrijavao čitavu prostoriju; za pečenje kruha jednom tjedno palila se krušna peć za nekoliko domaćinstava. Samo jedan staklar, koji je nabavljao ravno staklo u daruvarskoj tvornici, nikako nije zadovoljavao potrebe stanovništva, pa su i tada prozori bili mali i rijetki. Dio tih usluga rješavao se preko putujućih staklara, kotlokrpa i prodavača sitne ukrasne robe koju su donosili pokućarci iz Kranjske i Češke, čije je poslovanje bilo regulirano posebnim pravilima.

Žene su u obrtu bile zapostavljene. Muški krojači šivali su kapute i odijela za građane dobrog imovnog stanja od uvezenih tkanina, a žensku odjeću - često tipičnu za određeni kraj - izrađivale su žene od lana i platna prateći čitav proces od polja do konačne suknje ili bluze, koje su ukrašavale i narodnim vezom. Zanimljivo je da je bilo mnogo tkalaca koji su izrađivali predmete od lana i platna. U Virju Ivančica Turković, supruga pok. slikara Turkovića, i ranas radi na tkalač-

${ }_{24}$ Hrvoje PETRIĆ, Mira KOLAR-DIMITRIJEVIĆ, Prilozi povijesti seljačkog pokreta u Podravini (Od početaka do 1945. godine), Meridijani, Koprivnica 1915. 
kom stanu torbe i ručnike, iako ima problema s nabavom konca. ${ }^{25}$ Međutim sve življi promet željeznicom doveo je i u Podravinu neke krojačice i izrađivačice šešira koje su svoj zanat izučile u modnim centrima Europe, a domaće vješte žene to su onda brzo kopirale. Dolazak novog stoljeća osjeća se u mnogim područjima života, pogotovo kada su pokrenuti prvi lokalni listovi.

Medičari i voštari, tradicionalno vrlo traženi na sajmovima i prošteništima, još uvijek zamjenjuju slastičare. U čitavoj Podravini nema nijedne kavane, ali ni nijednog pravog hotela. Plemstvo koje je, radi ugošćivanja državnih i vojnih predstavnika, otvorilo ugostiteljske objekte pod nazivima K caru austrijskome i sl. bilo je već osiromašeno zbog krize 1873. te, ne snalazeći se u novim vremenima, rado ulazi u javne službe. Židovi pak nastupaju složno, pomažući jedni druge, te se već 1890 . vidi njihova dominacija u trgovini i ugostiteljstvu. Bave se i nakupom poljoprivrednih proizvoda i stoke, a oni uspješni, kada steknu potrebni kapital, prelaze u gradove i tamo grade kuće koje potvrđuju njihov ugled kao trgovaca, bankara, tvorničara. Iznenađuje što u današnjoj Koprivničko-križevačkoj županiji 1890. nije bilo nijedne vinare, tj. trgovine koja bi prodavala vino, a pivar je bio samo jedan, i to Katz u Križevcima. Slabe su i prijevozničke djelatnosti. Još nema kamiona ni automobila, ali na čitavom tom području nema ni foringaša, pa moramo prepostaviti da su robu prevozili seljaci koji su imali konje i koji se nisu posebno registrirali kao nositelji uslužne djelatnosti. Fijakerist je bio samo jedan, i to u Križevcima. Seljaci s malo zemlje prihvaćali su se i svakog sezonskog posla, pa su se tako izrađivale cigle u poljskim ciglanama, ali se tako obavljala i sječa šuma. Zanimljivo je da se na čitavom području nijedan čovjek ne iskazuje kao ribar, iako je nezamislivo da se riba iz Drave ne lovi. Možda su se oni iskazivali kao poljoprivrednici.

Zbog Drave, u kojoj su se ljudi ljeti kupali, nema ni javnog kupališta osim onog u Križevcima. Građani Križevaca kao da su imali neki bolji standard, sudeći po raznolikijem obrtništvu. To bi moglo biti tako zbog onih koji su radili u županijskim službama do 1886., odnosno onih koji su se kao stranci zaposlili u Gospodarskoj školi u Križevcima, pa je tamo, zbog njihovih potreba, bilo više vrsta obrtnika nego u Koprivnici - što je u skladu s činjenicom da su Križevci do 1886. bili županijsko središte, pa su neki činovnici, a i plemstvo, nakon umirovljenja nastavili živjeti u tom gradu.

25 Televizijska emisija Pozitiono 24. rujna 2020. 
Rad Hrvat. akad. znan. i umjet. Razred za druš. znan. 55=545(2021) : 31-102

\begin{tabular}{|c|c|c|c|c|c|c|c|c|c|c|c|c|c|c|c|c|c|c|c|c|c|}
\hline & 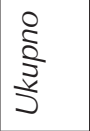 & & & $\stackrel{0}{t}$ & & $m$ & $\stackrel{\infty}{\sim}$ & $\stackrel{m}{-}$ & . & & , & - & $\infty$ & . & ' & . & I & ' & ' & , & हो \\
\hline & 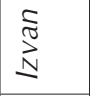 & , & & $\hat{\imath}$ & , & - & $\stackrel{\circ}{2}$ & - & 1 & ' & ' & ' & $\wedge$ & ' & ' & ' & $\therefore$ & ' & ' & ' & 6 \\
\hline $\begin{array}{c}0 \\
\frac{1}{2} \\
\frac{2}{5}\end{array}$ & 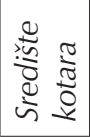 & I & ' & 2 & . & $v$ & $\stackrel{\infty}{=}$ & $\cong$ & ' & ' & ' & - & - & I & ' & I & I & ' & ' & ' & in \\
\hline & $\frac{0}{\frac{2}{2}}$ & , & , & $\stackrel{\llcorner}{\sim}$ & , & $v$ & $\cong$ & - & I & ' & , & , & - & , & , & I & I & , & ' & ' & - \\
\hline$\underset{\mathbb{Z}}{U}$ & 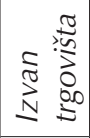 & . & ' & $\bar{v}$ & . & - & $\infty$ & ' & ' & ' & I & ' & - & ' & ' & . & I & ' & ' & ' & - \\
\hline 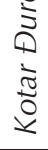 & 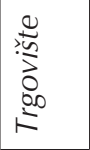 & ' & ' & $\nabla$ & I & - & $\nabla$ & - & & ' & I & ' & ' & I & ' & . & I & ' & ' & 1 & I \\
\hline & $\stackrel{\widetilde{\sigma}}{5}$ & ' & ' & $\approx$ & , & , & $\infty$ & $\operatorname{Ln}$ & ' & , & , & , & $\nabla$ & , & , & , & , & I & ' & ' & $\stackrel{6}{\sim}$ \\
\hline ¿্য & 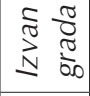 & . & . & $v$ & ' & . & $v$ & ' & ' & ' & ' & ' & $\forall$ & I & ' & . & I & I & ' & I & - \\
\hline $\begin{array}{l}\grave{\Xi} \\
\stackrel{0}{0}\end{array}$ & $\frac{\mathfrak{T}}{\mathrm{U}}$ & ' & ' & $\stackrel{ }{2}$ & . & ' & 6 & $\ln$ & . & I & I & , & $\therefore$ & I & , & I & I & I & I & ' & $\stackrel{L n}{\sim}$ \\
\hline$\widetilde{\mho}$ & 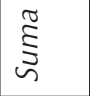 & ' & ' & $a$ & ' & - & $\infty$ & $\wedge$ & ' & . & ' & - & $m$ & I & , & ' & I & , & - & ' & \& \\
\hline 文 & 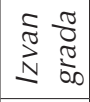 & . & ' & $\nabla$ & . & ' & ' & - & ' & ' & . & ' & $v$ & ' & ' & $\therefore$ & I & ' & ' & ' & $\theta$ \\
\hline 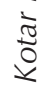 & $\stackrel{\pi}{0}$ & ' & ' & Ln & , & - & $\infty$ & 0 & ' & 1 & , & - & - & , & ' & I & , & , & - & , & n \\
\hline $\begin{array}{l}\frac{\pi}{ \pm} \\
\pm\end{array}$ & & & $\frac{\frac{5}{\frac{1}{\pi}}}{\frac{\pi}{\frac{\pi}{2}}}$ & 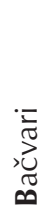 & 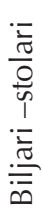 & 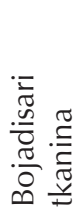 & 弯 & : & $\begin{array}{l}\frac{\bar{t}}{\frac{1}{0}} \\
\frac{0}{0}\end{array}$ & 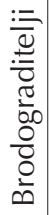 & 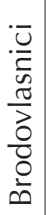 & 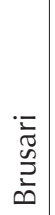 & 竞 & 竞 & 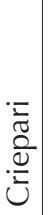 & 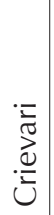 & 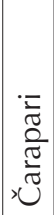 & : & : & 施 & : \\
\hline$\frac{2}{\infty}$ & & - & $v$ & $m$ & $\nabla$ & $\operatorname{Ln}$ & 6 & $\Lambda$ & $\infty$ & $a$ & 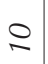 & $=$ & $N$ & $m$ & \pm & $\stackrel{L n}{\sim}$ & $\stackrel{0}{2}$ & 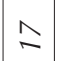 & $\stackrel{\infty}{\sim}$ & 2 & $\curvearrowright$ \\
\hline
\end{tabular}


Rad Hrvat. akad. znan. i umjet. Razred za druš. znan. 55=545(2021) : 31-102

\begin{tabular}{|c|c|c|c|c|c|c|c|c|c|c|c|c|c|c|c|c|c|c|c|}
\hline 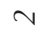 & Ln & I & 1 & - & 1 & ' & $\pi$ & 1 & ' & 1 & ' & ' & ' & I & ' & I & I & 1 & I \\
\hline- & ' & 1 & ' & I & ' & ' & $a$ & ' & ' & I & I & I & I & I & I & I & I & I & I \\
\hline- & $\operatorname{Ln}$ & I & $i^{\circ}$ & - & 1 & I & $\infty$ & I & I & 1 & ' & 1 & 1 & I & I & I & I & 1 & I \\
\hline I & - & ' & $1^{\circ}$ & I & ' & I & $\operatorname{Ln}$ & I & I & I & ' & I & ' & ' & I & 1 & I & 1 & I \\
\hline ' & I & I & $i^{\circ}$ & 1 & 1 & I & $m$ & I & I & 1 & 1 & I & 1 & I & 1 & I & I & 1 & I \\
\hline I & - & 1 & $1^{\circ}$ & 1 & 1 & I & $v$ & 1 & I & 1 & 1 & I & 1 & I & I & 1 & I & 1 & ' \\
\hline- & $v$ & I & $i^{\circ}$ & - & 1 & I & $\nabla$ & I & I & 1 & 1 & I & 1 & I & 1 & I & I & 1 & 1 \\
\hline ' & ' & I & $i^{\circ}$ & 1 & 1 & 1 & $m$ & I & I & 1 & 1 & I & 1 & I & I & 1 & I & 1 & 1 \\
\hline- & $v$ & I & I & - & 1 & 1 & - & 1 & I & 1 & I & I & 1 & I & 1 & 1 & I & 1 & I \\
\hline- & $v$ & 1 & $i^{\circ}$ & I & 1 & 1 & $\infty$ & 1 & I & I & I & I & 1 & I & I & 1 & I & 1 & I \\
\hline 1 & ' & ' & ' & 1 & I & I & $m$ & I & ' & 1 & I & I & I & I & I & I & I & I & I \\
\hline- & $v$ & I & '. & I & 1 & ' & $\operatorname{Ln}$ & I & ' & I & 1 & I & I & I & I & I & I & I & 1 \\
\hline $\begin{array}{l}\text { in } \\
\frac{\pi}{0} \\
0 \\
0\end{array}$ & ل & 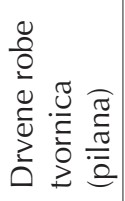 & 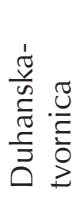 & 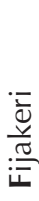 & 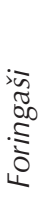 & $\begin{array}{l}\frac{1}{0} \\
\frac{0}{00} \\
\frac{1}{0} \\
1\end{array}$ & 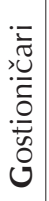 & 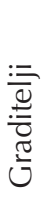 & 竝 & 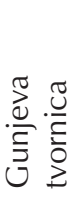 & 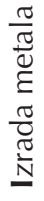 & 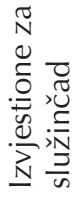 & 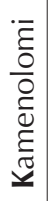 & 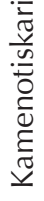 & 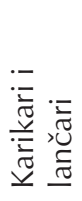 & 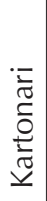 & 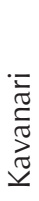 & 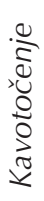 & $\frac{\frac{1}{0}}{\frac{0}{0}}$ \\
\hline $\bar{v}$ & $\widetilde{V}$ & $\stackrel{n}{v}$ & $\stackrel{\nabla}{\sim}$ & $\stackrel{\text { ㅇ }}{\vee}$ & $\stackrel{\bullet}{v}$ & $\widehat{\vartheta}$ & $\stackrel{\infty}{\sim}$ & $\stackrel{\Omega}{v}$ & $\stackrel{r}{m}$ & $\bar{m}$ & m & $m$ & m & $\stackrel{\operatorname{n}}{m}$ & $\stackrel{0}{m}$ & $\hat{m}$ & $\infty$ & m & $\vartheta$ \\
\hline
\end{tabular}




\begin{tabular}{|c|c|c|c|c|c|c|c|c|c|c|c|c|c|c|c|c|c|c|c|c|c|}
\hline ' & - & , & - & . & $\stackrel{L n}{=}$ & - & & $\nabla$ & 市 & , & $v$ & $\begin{array}{l}0 \\
\infty \\
\sim\end{array}$ & $\forall$ & , & 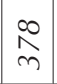 & $\infty$ & $\infty$ & & $\bar{m}$ & $m$ & \\
\hline . & ' & ' & ' & 1 & - & , & & - & $\tilde{n}$ & , & . & $\stackrel{g}{ \pm}$ & , & ' & $\hat{\curvearrowright}$ & $\stackrel{\curvearrowright}{\sim}$ & . & & $\curvearrowright$ & ' & \\
\hline . & - & , & - & , & $\underset{\sim}{ \pm}$ & - & , & $m$ & $\stackrel{+}{m}$ & , & $v$ & $\hat{n}$ & $\nabla$ & , & $\stackrel{\infty}{\circ}$ & ţ & $\infty$ & - & $\approx$ & $m$ & I \\
\hline ' & ' & ' & . & ' & . & , & I & , & $\stackrel{\text { Ln }}{m}$ & ' & , & $\widehat{b}$ & , & , & $\stackrel{\operatorname{Ln}}{\llcorner\cap}$ & $\lesssim$ & , & , & 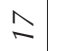 & , & , \\
\hline ' & ' & ' & 1 & 1 & , & . & . & , & $\bar{v}$ & , & , & 요 & , & , & भे & $\approx$ & , & & \pm & , & \\
\hline ' & ' & ' & ' & ' & ' & ' & , & ' & $\underset{\sim}{*}$ & ' & , & $\triangleq$ & ' & ' & 0 & $\stackrel{v}{\sim}$ & , & , & $m$ & , & , \\
\hline ' & - & , & - & , & $\infty$ & , & , & $m$ & $\stackrel{一}{n}$ & , & - & gे & - & , & $\bar{\nabla}$ & $\stackrel{\llcorner}{\mathcal{V}}$ & $v$ & - & , & , & \\
\hline , & ' & , & , & . & - & , & . & - & $\stackrel{L n}{=}$ & , & , & 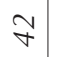 & , & , & $\hat{\sigma}$ & $\ln$ & , & , & , & , & I \\
\hline , & - & , & - & , & $\wedge$ & , & , & $v$ & $\stackrel{L n}{=}$ & , & - & $\wedge$ & - & , & $\stackrel{\infty}{\forall}$ & $\stackrel{\vartheta}{\sim}$ & $\sim$ & - & , & , & I \\
\hline ' & ' & ' & ' & ' & $\wedge$ & - & ' & - & $\approx$ & ' & - & $尺$ & $n$ & , & $\stackrel{+}{0}$ & & 0 & , & \pm & $m$ & , \\
\hline . & 1 & 1 & 1 & 1 & , & . & 1 & ' & $\lesssim$ & 1 & , & Lิ & , & . & 8 & $\nabla$ & , & ' & $\ln$ & , & ' \\
\hline ' & I & ' & ' & , & $\Lambda$ & - & ' & - & $\ln$ & I & - & $\stackrel{m}{\sim}$ & $m$ & , & 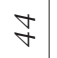 & $\stackrel{\infty}{v}$ & 6 & , & $a$ & $m$ & ' \\
\hline$\frac{\mathfrak{a}}{\frac{a}{2}}$ & 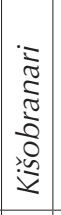 & 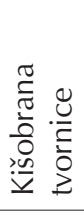 & 意 & 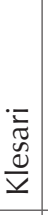 & 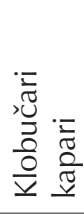 & 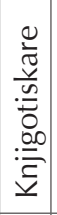 & 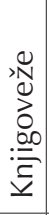 & 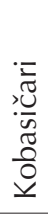 & $\begin{array}{l}\frac{2}{\bar{t}} \\
\frac{\pi}{0} \\
\frac{1}{2}\end{array}$ & 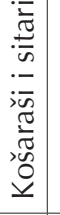 & 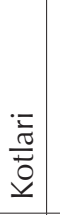 & 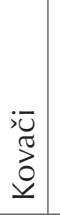 & 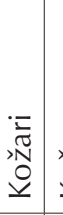 & 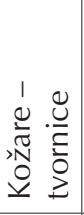 & 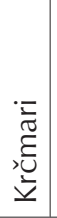 & $\begin{array}{l}i \bar{v} \\
\frac{\sigma}{0} \\
\dot{\underline{\nu}}\end{array}$ & 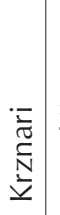 & 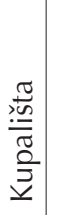 & 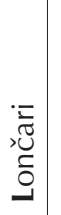 & 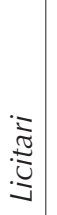 & $\frac{\bar{U}}{i ! U}$ \\
\hline $\bar{\gamma}$ & $\mathscr{\forall}$ & & $\tilde{\gamma}$ & & $\underset{\forall}{\forall}$ & $\stackrel{\operatorname{Ln}}{\sigma}$ & $\vartheta$ & $\hat{\gamma}$ & $\begin{array}{l}\infty \\
+ \\
+\end{array}$ & 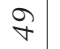 & $\stackrel{\circ}{\llcorner n}$ & $\overline{L n}$ & กิ & in & L & $\begin{array}{l}\operatorname{Ln} \\
\mathrm{Ln}\end{array}$ & $L_{0}^{\circ}$ & $\hat{n}$ & $\begin{array}{l}\infty \\
i n\end{array}$ & हn & ஜ \\
\hline
\end{tabular}


Rad Hrvat. akad. znan. i umjet. Razred za druš. znan. 55=545(2021) : 31-102

\begin{tabular}{|c|c|c|c|c|c|c|c|c|c|c|c|c|c|c|c|c|c|}
\hline , & $\cong$ & Ln & , & , & $\bar{\gamma}$ & - & . & 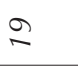 &, & $\begin{array}{l}\infty \\
\infty\end{array}$ & ' & $\stackrel{\hat{L}}{\sim}$ & $\Lambda$ & $v$ & - & , & t \\
\hline . & $\approx$ & - & , & , & $\stackrel{L n}{\sim}$ & , &. & $=$ & , & $\stackrel{\gamma}{\nabla}$ & , & $\tilde{v}$ & $v$ & , & - & , & $m$ \\
\hline , & $\operatorname{Ln}$ & $\nabla$ & , & , & $\stackrel{\bullet}{v}$ & - & , & $\infty$ & , & ळે & , & $\stackrel{\llcorner}{\sim}$ & $\ln$ & $v$ & , & , & $\bar{n}$ \\
\hline , & $v$ & $v$ & ' & , & , & i & , & $m$ & , & $\infty$ & , & $\begin{array}{l}\infty \\
\infty\end{array}$ & , & , & - & , & $\stackrel{0}{\sim}$ \\
\hline ' & $\sim$ & - & ' & ' & , & ' & , & $=$ & , & $\nabla$ & , & $\stackrel{\llcorner N}{\wedge}$ & , & , & - & , & 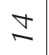 \\
\hline , & , & - & , & , & '. & , & , & $\nu$ & , & $\nabla$ & , & $m$ & , & , & , & , & $v$ \\
\hline , & \pm & - & , & , & $\hat{\curvearrowright}$ & , & , & $m$ &, & $\stackrel{\infty}{+}$ & , & जे & $\nabla$ & - & , & , & $\stackrel{\infty}{v}$ \\
\hline , & $\stackrel{ }{\sim}$ & , & , & , & 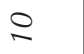 & , &, & , & , & m & , & $\stackrel{n}{n}$ & - & , & , & , & $\stackrel{n}{\sim}$ \\
\hline , & $\nabla$ & - & . & , & $\cong$ & . & , & $m$ & , & $\stackrel{v}{\sim}$ & , & $\nabla$ & $m$ & - & , & , & $\stackrel{L n}{\sim}$ \\
\hline ' & - & $v$ & 1 & , & \pm & - & $\because$ & $n$ & , & กै & 1 & $\stackrel{ }{=}$ & $m$ & - & . & , & $\stackrel{\curvearrowright}{\sim}$ \\
\hline 1 & ' & ' & ' & ' & Ln & ' & 1 & , & ' & 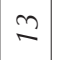 & . & 끔 & - & , & , & ' & 0 \\
\hline 1 & - & $N$ & ' & 1 & $\sigma$ & - & '. & $\dot{m}$ & , & $\stackrel{9}{2}$ & . & $\infty$ & $v$ & - & , & ' & $\underset{\leftarrow}{ \pm}$ \\
\hline 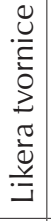 & 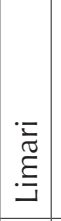 & 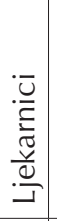 & 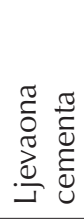 & $\begin{array}{l}i \overline{\widetilde{J}} \\
\stackrel{\vec{J}}{\unlhd} \\
\end{array}$ & 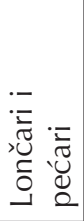 & 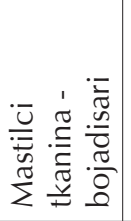 & 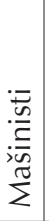 & 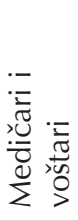 & 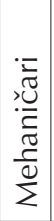 & $\begin{array}{l}\cdot= \\
\text { d } \\
\mathscr{d} \\
\sum\end{array}$ & 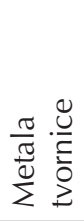 & : & 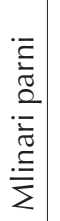 & $\begin{array}{l}-\bar{T} \\
\text { N } \\
0 \\
\mathbf{Z}\end{array}$ & :- & 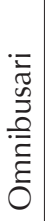 & 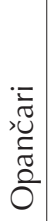 \\
\hline$\overline{6}$ & ซै & $\hat{\theta}$ & రु & $\hat{6}$ & 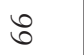 & $\hat{\jmath}$ & $\stackrel{\infty}{0}$ & જે & $尺$ & $\bar{\lambda}$ & $N$ & $\Re$ & & $\stackrel{\llcorner n}{\wedge}$ & 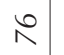 & $\hat{\wedge}$ & $\stackrel{\infty}{\wedge}$ \\
\hline
\end{tabular}


Rad Hrvat. akad. znan. i umjet. Razred za druš. znan. 55=545(2021) : 31-102

\begin{tabular}{|c|c|c|c|c|c|c|c|c|c|c|c|c|c|c|c|c|c|c|c|c|}
\hline$v$ & $m$ & 1 & ' & I & ' & 1 & $\forall$ & & - & $\stackrel{\operatorname{Ln}}{\sim}$ & 1 & - & 1 & 1 & I & $\infty$ & & I & I & $\underset{\sim}{ \pm}$ \\
\hline 1 & - & I & 1 & ' & ' & 1 & $\nabla$ & & - & $\underset{I}{ \pm}$ & 1 & 1 & ' & ' & ' & Ln & ' & I & ' & $\stackrel{\circ}{N}$ \\
\hline$v$ & $v$ & I & ' & $i$ & ' & ' & ' & & ' & $=$ & I & - & 1 & I & I & $m$ & , & 1 & I & $\stackrel{n}{\wedge}$ \\
\hline- & $n$ & I & ' & i & ' & ' & - & $i$ & ' & $\infty$ & I & 1 & 1 & ' & 1 & - & 1 & i & ' & $\stackrel{\infty}{\forall}$ \\
\hline ' & - & I & ' & 1 & ' & 1 & - & ' & 1 & Ln & ' & 1 & 1 & ' & 1 & ' & ' & 1 & I & $\stackrel{\infty}{\sim}$ \\
\hline- & $v$ & I & ' & ' & 1 & 1 & 1 & I & 1 & $n$ & I & 1 & 1 & 1 & 1 & - & I & I & 1 & $\stackrel{\vartheta}{\vartheta}$ \\
\hline 1 & 1 & 1 & 1 & $\therefore$ & ' & 1 & $m$ & '. & - & Ln & $i^{\circ}$ & - & I & ' & I & 6 & I & I & I & 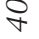 \\
\hline 1 & 1 & I & '. & I & . & 1 & $m$ & I & - & $v$ & 1 & 1 & ' & 1 & I & Ln & 1 & I & i & $\stackrel{\ominus}{\sim}$ \\
\hline I & ' & 1 & $i^{\circ}$ & i & I & 1 & 1 & ': & '. & $m$ & 1 & $\tau$ & 1 & 1 & I & - & , & I & 1 & $\stackrel{\vartheta}{\vartheta}$ \\
\hline- & ' & 1 & 1 & ' & ' & 1 & ' & I & 1 & $\underset{N}{N}$ & 1 & 1 & ' & 1 & I & - & 1 & I & 1 & $\bar{\sigma}$ \\
\hline 1 & ' & I & ' & 1 & ' & 1 & ' & ' & ' & $\wedge$ & ' & ' & ' & ' & I & ' & ' & 1 & ' & $\stackrel{\infty}{\sim}$ \\
\hline- & 1 & 1 & ' & I & ' & 1 & ' & 1 & ' & เก & 1 & 1 & I & 1 & I & - & I & I & I & $m$ \\
\hline 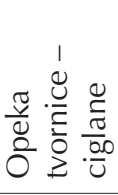 & 竎 & 咅 & 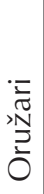 & 永 & $\begin{array}{c}\frac{0}{\infty} \\
\frac{\sigma}{2} \\
\vdots \\
\frac{1}{\sigma} \\
0\end{array}$ & $\begin{array}{l}\frac{1}{2} \\
\frac{1}{0} \\
0 \\
\frac{0}{0} \\
0\end{array}$ & 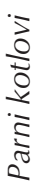 & 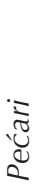 & 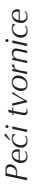 & $\frac{0}{\frac{\pi}{0}}$ & $\frac{\stackrel{0}{\frac{D}{\pi}}}{\ddot{D}}$ & $\begin{array}{l}\frac{1}{2} \\
\frac{0}{2} \\
0 \\
0 \\
0\end{array}$ & 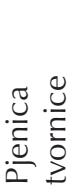 & 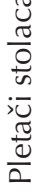 & 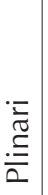 & 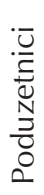 & 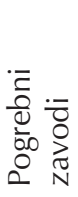 & 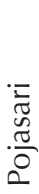 & $\begin{array}{l}\cdot \frac{1}{\sqrt{0}} \\
\frac{5}{5} \\
\frac{0}{0} \\
0\end{array}$ & $\begin{array}{l}\frac{1}{\frac{\pi}{0}} \\
\frac{0}{5} \\
0 \\
0\end{array}$ \\
\hline 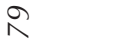 & 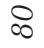 & $\bar{\infty}$ & $\infty$ & $\infty$ & $\underset{\infty}{+}$ & $\stackrel{1}{\infty}$ & $\underset{\infty}{\infty}$ & $\widehat{\infty}$ & $\begin{array}{l}\infty \\
\infty\end{array}$ & $\infty$ & Ћ & $\bar{a}$ & ๙ૈ & n̆ & જૈ & ๙ & ఫ̆ & คी & ด้ & مิ \\
\hline
\end{tabular}


Rad Hrvat. akad. znan. i umjet. Razred za druš. znan. 55=545(2021) : 31-102

\begin{tabular}{|c|c|c|c|c|c|c|c|c|c|c|c|c|c|c|c|c|c|c|}
\hline I & 1 & ' & ' & ' & $\infty$ & ' & ' & ' & 1 & - & 1 & $\stackrel{v}{\sim}$ & 1 & ' & ' & - & $m$ & \\
\hline i & I & , & , & I & $v$ & , & , & I & , & 1 & I & - & 1 & I & I & - & , & 1 \\
\hline I & i & i & I & ' & 6 & ' & ' & ' & ' & - & ' & $\stackrel{2}{=}$ & ' & i & I & I & $n$ & 1 \\
\hline I & I & I & I & 1 & $\nabla$ & I & I & I & 1 & I & I & $m$ & 1 & 1 & 1 & - & 1 & 1 \\
\hline 1 & ' & 1 & 1 & ' & - & ' & I & I & ' & 1 & ' & ' & ' & I & I & - & I & 1 \\
\hline 1 & ' & 1 & I & 1 & $m$ & , & 1 & 1 & 1 & I & 1 & $m$ & 1 & 1 & I & 1 & 1 & 1 \\
\hline 1 & 1 & 1 & ' & 1 & - & ' & $i^{\circ}$ & 1 & ' & $1^{\circ}$ & 1 & $\stackrel{\circ}{\sim}$ & ' & I & I & I & - & 1 \\
\hline 1 & 1 & 1 & I & 1 & - & $i^{\circ}$ & $i^{\circ}$ & 1 & $1^{\circ}$ & $1^{\circ}$ & ' & - & 1 & I & 1 & I & I & 1 \\
\hline I & ' & I & I & I & 1 & I & $i^{\circ}$ & I & ' & '. & 1 & $a$ & 1 & I & 1 & 1 & - & ' \\
\hline I & ' & 1 & I & I & $m$ & I & I & I & ' & - & ' & $m$ & 1 & I & I & 1 & V & 1 \\
\hline 1 & ' & 1 & 1 & ' & ' & ' & ' & I & ' & 1 & ' & ' & ' & I & 1 & 1 & ' & ' \\
\hline 1 & ' & ' & ' & 1 & $m$ & ' & ' & 1 & ' & - & ' & $n$ & ' & ' & 1 & I & $v$ & ' \\
\hline 章 & 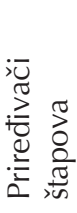 & $\frac{\sqrt{\frac{\pi}{\sigma}}}{\frac{\pi}{D}}$ & 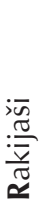 & 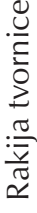 & 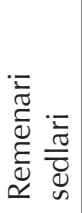 & 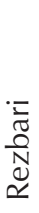 & $\begin{array}{l}\overline{\bar{\pi}} \\
\frac{\bar{\sigma}}{\bar{\alpha}}\end{array}$ & 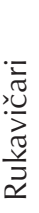 & 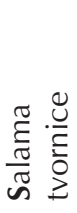 & 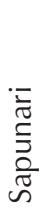 & 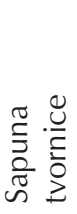 & 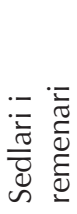 & : $\frac{\bar{\sigma}}{\bar{n}}$ & 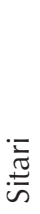 & 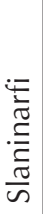 & 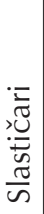 & 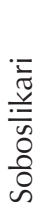 & 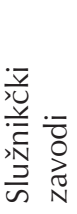 \\
\hline $\begin{array}{l}\infty \\
\text { ดे }\end{array}$ & જ) & 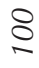 & 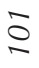 & $\stackrel{\vartheta}{\varrho}$ & 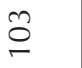 & $\underset{\leftarrow}{\stackrel{\Xi}{0}}$ & $\stackrel{\text { 농 }}{0}$ & $\stackrel{\varrho}{\varrho}$ & $\hat{⿵}$ & $\stackrel{\infty}{\varrho}$ & g) & $\stackrel{0}{ }$ & 立 & $\underset{\leftarrow}{\check{E}}$ & $\stackrel{m}{=}$ & & $\frac{\text { ㄴ) }}{\sqsubset}$ & $\begin{array}{l}0 \\
=\end{array}$ \\
\hline
\end{tabular}


Rad Hrvat. akad. znan. i umjet. Razred za druš. znan. 55=545(2021) : 31-102

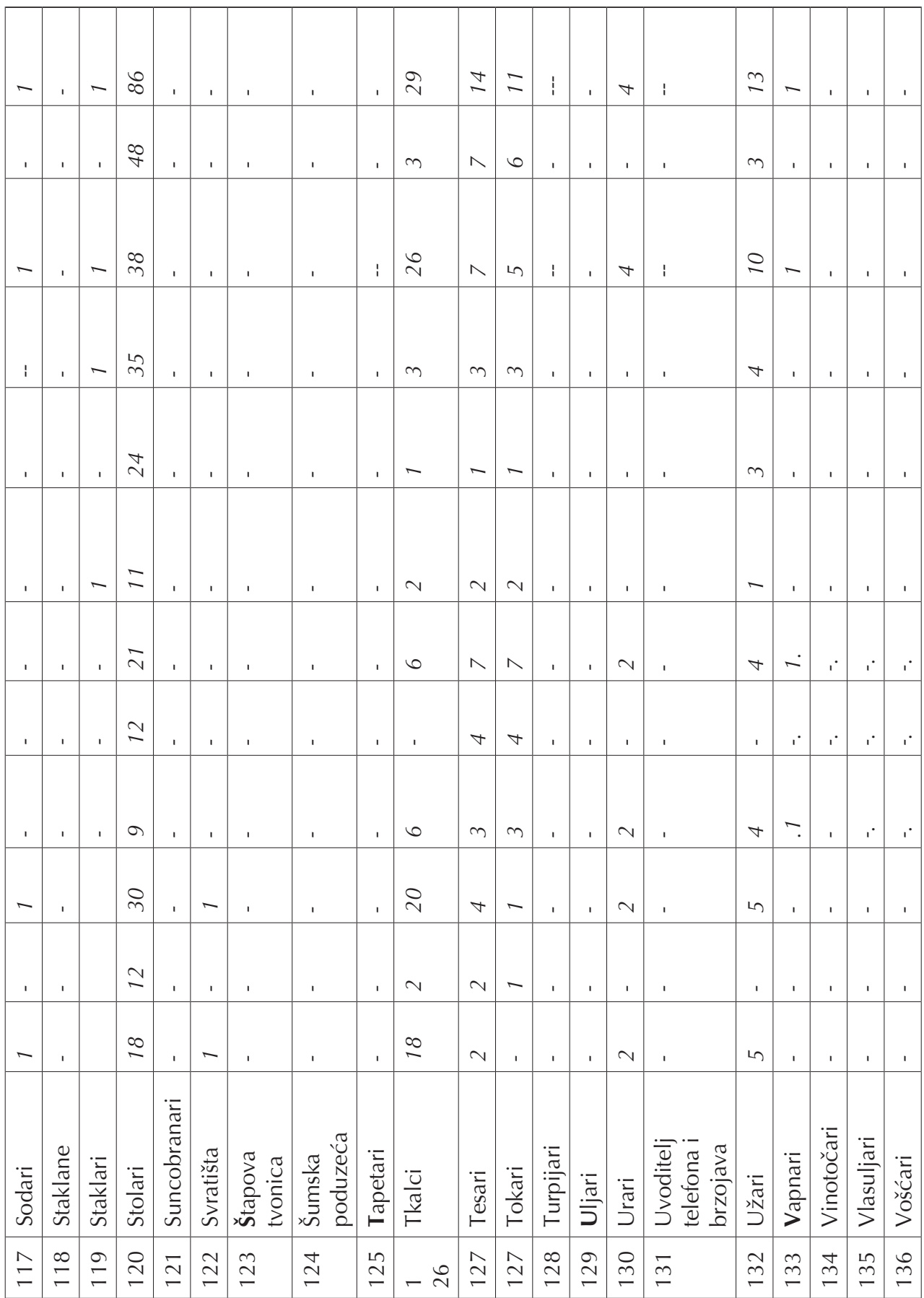


Rad Hrvat. akad. znan. i umjet. Razred za druš. znan. 55=545(2021) : 31-102

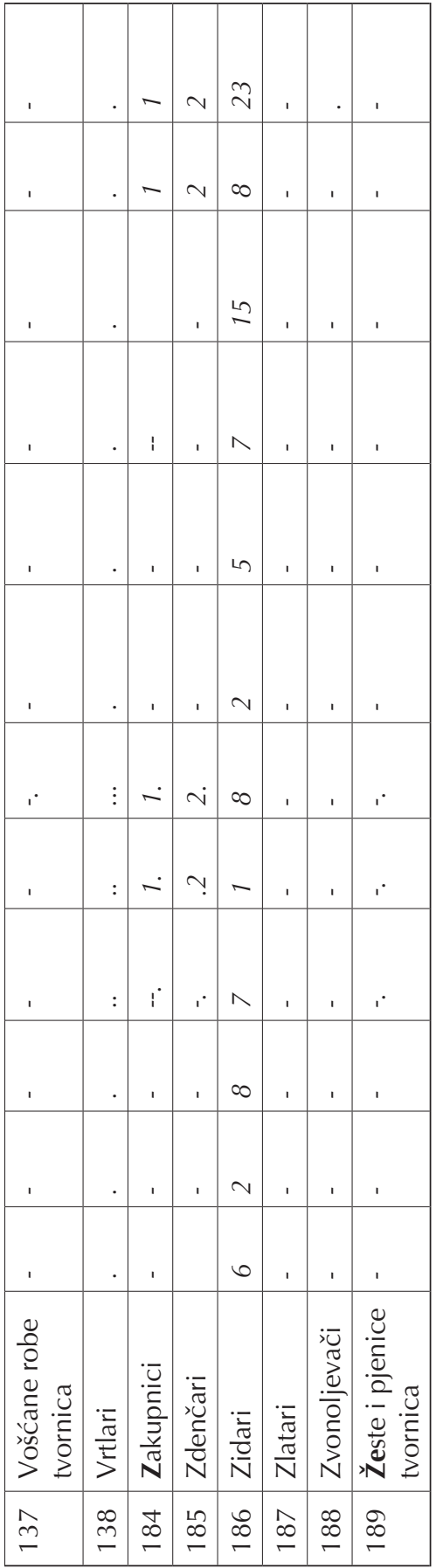

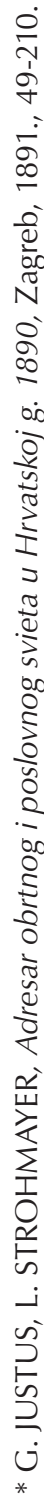


Tablica 10 ne omogućava nam stvaranje cjelovitih zaključaka o životu obrtnika niti nam daje pravu sliku o broju tvornica. Osim broja, Adresar ne donosi nikakve podatke o kvalifikacijama obrtnika ni o njihovu društvenom statusu. Ipak, broj obrtnika po prezimenima govori o velikoj šarolikosti obrtnika, a činjenica da su mnogi na promatranom području pokušali poslovati ukazuje da su tamo postojale velike mogućnosti za zaradu. Stoga bi ova istraživanja trebalo nadopuniti biografijama pojedinih obrtnika, tamo gdje je arhivska građa očuvana.

Na našem području nisu zastupljene sve obrtničke struke. Od 189 navedenih registriranih obrtničkih struka u Adresaru, na području današnje Koprivničkokriževačke županije nije registrirana ni polovica. Ipak, bilo ih je dovoljno u onim strukama koje su bile najpotrebnije stanovništvu. A ženski je rad, dakako, nevidljiv iz Adresara, iako je bio gotovo svugdje prisutan u obrtničkim radnjama.

Etnički obrtnici bili su pripadnici raznih naroda, ali su bili vrlo nejednako raspoređeni na čitavom promatranom području. Njihov se broj povećavao već za Bachova apsolutizma, odnosno potkraj Jelačićeva banovanja, a uvećavao se i za vrijeme trajanja Hrvatsko-ugarske nagodbe. Godine 1840. bilo je u Hrvatskoj i Slavoniji 3.250 Mađara ili 0,32\%, a Nijemaca 30.200 ili 3\%; godine 1890. u Hrvatskoj i Slavoniji već su živjela 68.794 Mađara ili 3,15\% stanovništva, a Nijemaca je bilo 117.490, odnosno 5,37\% stanovnika; takav se rast svakako morao odraziti i u društvu. ${ }^{26}$ Mađari su poslije 1868. ulazili u Hrvatsku uglavnom radi poslova izgradnje željeznica, čime su poticali i doseljavanje Slovaka i Moravaca kao radnika ili službenika na željeznici. S obzirom na to da su financijski poslovi pripadali mađarskoj vladi, Mađari su za ubiranje poreza koristili svoje ljude ili Kranjce. Nijemce pak nalazimo svugdje, iako su se pod utjecajem narodnjaštva oni sve više kroatizirali mijenjajući svoja prezimena i imena; samo su Židovi, koje nalazimo većinom kao krčmare i trgovce, njegovali svoju posebnu kulturu i vjeru.

U svakom slučaju, porijeklo obrtnika i trgovaca još je uvijek intrigantan problem koji zahtijeva interdisciplinarna istraživanja. Razvojačenjem Vojne krajine privučeni su i mnogi Srbi iz nerazvijenih područja prema sjeveru Hrvatske, a ban Khuen-Héderváry pronašao je u mnogima provoditelje svoje politike. Prema Leksikonu prezimena akademika Petra Šimunovića, prevladavali su obrtnici koji su potjecali od autohtonog stanovništva, ali su izučavanjem obrta u Austriji ili Mađarskoj obrtnici koji su otvarali obrte u našoj zemlji prenosili obrtničke vještine i jezik iz tih krajeva. To se osobito uočava kod naziva alata, ali i u zastupljenosti obrtnika u općinskim i gradskim samoupravama. Te samouprave u Koprivnici i Križevcima postoje do 1895., kada su gradovi, na temelju Zakona o ustroju gradskih općina od 21. lipnja 1895., potpali pod županije i izgubili

26 Milan MARJANOVIĆ, Savremena Hrvatska, Beograd, 1913., str. 179. 
veći dio svoje samouprave te su sve odluke morale odobravati županijske vlasti. Domaća su prezimena s dočetkom na -ić i izvedenice prema zanimanjima najbrojnija, što ukazuje na to da domaći obrt potječe iz cehovskog, a možda i izvancehovskog kruga, te da su spretniji krajišnici, odnosno seljaci radili i neke obrtničke poslove potrebne okolnom stanovništvu. Patentom Josipa II. iz 1890. Židovi su dobili nova prezimena, a kmetovi slobodu kretanja radi izučavanja obrta, te od tog vremena možemo preko matičnih knjiga rođenih, umrlih i vjenčanih pratiti kretanje ljudi, pa i obrtnika. Uočavamo usku vezanost prezimena s obrtničkim poslom. Mnogi Kolari doista su se bavili izradom kola, a Kovači su obrađivali alatke od željeza. Zanimljivo je da se nitko ne preziva Bravar. Brojni obrtnici nose prezime Horvat, što ukazuje na njihovu nacionalnu pripadnost, ali i činjenicu da su dio života proboravili izvan Hrvatske, gdje su vjerojatno radili kao nadničari ili pak kalfe učeći se obrtu.

U svakom slučaju 1.485 obrtnika na području današnje Koprivničko-križevačke županije bilo je dovoljno da zadovolji najnužnije i svakodnevne potrebe za obrtnim uslugama. Dosta obrtnih radnji drži pravoslavno stanovništvo, koje u tom vremenu ima dobar suživot s domaćim katoličkim stanovništvom. Stranci su ipak vrlo brojni: Štajerci, Slovenci koje zovu Kranjci, Mađari, Česi, Moravci, Poljaci, Talijani i Židovi, a kovač Stjepan Redjep i krojačica Bara Redjep u Đurđevcu upućuju na neku staru imigraciju s područja Kosova ili Albanije. Treba uočiti velik broj slovenskih obrtnika. Oni su naime gotovo jednakopravni s domaćima, čemu pridonosi kajkavski dijalekt, ali i vrijeme kada su pravaši Slovence nazivali "planinskim Hrvatima“. Slovenci, tj. Ivan Hribar i Bleiweis, posjetili su ljeti 1891. Gospodarsku izložbu u Zagrebu pregovarajući o što užem povezivanju Slovenaca i Hrvata. ${ }^{27}$

Tablica 11 rađena je na osnovi svih tablica u ovom radu te omogućava donošenje nekih zaključaka.

Tablica 11. Usporedba broja obrtnika u tri nekadašnja kotara današnje Koprivničko-križevačke županije 1890. godine*

\begin{tabular}{|l|l|l|l|l|l|l|}
\hline Kotar Koprivnica & & Kotar Križevci & & Kotar Đurdevac & & Ukupno \\
\hline Grad & Izvan & Grad & Izvan & Trgovište & Izvan & \\
\hline 324 & 332 & 283 & 400 & 143 & 303 & 1.485 \\
\hline Ukupno 656 & & 683 & & 446 & & 1.485 \\
\hline
\end{tabular}

* Izračunato na temelju uvida u tablice u ovom radu.

27 Marko ZAJC, Gdje slovensko prestaje, a hrvatsko počinje - Slovensko-hrvatska granica u XIX. i početkOM XX. stoljeća, Srednja Europa, Zagreb, 2008. 
Podaci iz tablice 11 potvrđuju da je na području današnje Koprivničko-križevačke županije djelovalo 1.485 obrtnika i obrtnica. Iznenađuje činjenica da je izvan gradova trgovišta djelovalo više obrtnika i obrtnica nego u središtima kotara, a to se osobito dobro može registrirati na primjeru Đurđevca. To potvrđuje ruralni karakter čitavog područja, gdje se mnogo toga rješavalo preko kućne radinosti, pa se za plaćenim uslugama posezalo samo onda kada su bila potrebna specijalna znanja. Ipak, nemamo podataka za starije vrijeme jer popisi prije 1857. godine nisu obrtnike i trgovce uzimali kao posebnu kategoriju, a i struktura društva bila je posve drugačija. Zanimljivo je da je Kotar Križevci imao 683 obrtnička subjekta te je bio nešto bogatiji obrtnicima nego Kotar Koprivnica sa 656 obrtnika, dok je Kotar Đurđevac s 446 subjekata znatno zaostajao za prva dva kotara. Bila je to posljedica ne samo zaostajanja u gospodarskom razvoju i osobito trgovini već i prometne izoliranosti, a možda i politike vlasti. Cesta Koprivnica - Đurđevac bila je dio godine neupotrebljiva za promet zbog poplava i slabog održavanja.

\section{Zaključak}

Na temelju podataka iz ovog rada postavlja se pitanje zašto je toliki broj obrtnika - od kojih su mnogi bili pripadnici drugih naroda - poželio živjeti na području današnje Koprivničko-križevačke županije. Razloga je više, a jedan od njih svakako se krije u činjenici što se to područje nalazilo na najkraćoj ruti od srednje Europe do mora i da je izgradnja željezničke pruge omogućila brzo i lagano kretanje na toj liniji. Drugi razlog svakako leži u još uvijek neiskorištenim prirodnim resursima. Iako su šume već bile poprilično devastirane u blizini prometnica, a osobito Drave, ipak je taj kraj još uvijek mogao davati velike količine građevnog drva za izvoz, a lignitski ugljen služio je kao gorivo lokomotivama na paru. Područje je bilo samodostatno u prehrani, pa se nešto od poljoprivrednih i stočarskih proizvoda moglo i izvoziti.

Obrtnici su u to doba bili stupovi društva - bili su važni za životni standard te su bili i važan faktor u javnom životu jer su bili pismeni, a većina ih je dobro poznavala struku zbog višegodišnjeg rada kod više majstora izvan rodnog mjesta. Oni su bili nosioci novog doba, ali i vjesnici vremena kada su se obrtnici, trgovci i industrijalci smatrali poslodavcima; na drugoj strani bili su radnici, koji su se počeli organizirati u socijaldemokratsku partiju, odnosno sindikate, i koji su se štrajkovima i tarifnim pokretima borili za kraći radni dan i bolje uvjete rada. ${ }^{28}$ Obrtnici koji su imigrirali iz drugih dijelova Austro-Ugarske Monarhije

28 Josip CAZI, Počeci modernog radničkog pokreta u Hrvatskoj, Zagreb, 1953.; Mira KOLAR, Obrtnici su najdugotrajnji čuvari tradicije i pokretači napretka, Katalog izložbe "Obrt i obrazovanje“ u Hrvatskom državnom arhivu 15. XII. 2006. - 31. I. 2007. 
lako su se udomaćili jer je Vojna krajina na vodeća mjesta postavljala one koji su govorili njemački i koji su promicali germanizaciju. Višestoljetne pak veze $\mathrm{Hr}$ vata u Podravini i Međimurju s Mađarima znatno su utjecale na opću kulturu. Ipak, postoje razlike između triju kotara koji se obrađuju u ovom radu. Bilo bi očekivano da je najviše obrtnika zabilježeno u Križevačkom kotaru i Križevcima, koji su bili i građanski i vojnički, ali i plemenitaški grad bogate tradicije, a do 1886. i županijsko središte. Najmanje je obrtnika i po broju i po strukama imao izolirani Đurđevački kotar, jer je trgovište Đurđevac tek krenulo u svoju preobrazbu iz krajiškog središta jedne pukovnije u središte kotara, gdje se trebalo izboriti s Virjem i Novigradom za prvo mjesto. Koprivnica nije nikada u prošlosti bila županijsko središte, ali je kao slobodni kraljevski grad očuvala kroz stoljeća znatan dio svoje slobode u borbi s krajiškom birokracijom, a onda joj je dolazak željeznice dao važnu trgovačku i izvoznu ulogu za područje od Đurđevca do Ludbrega, pa i šire.

Dakako da je bilo i velikih prepreka brzom razvoju, ali su se one polagano rješavale nakon ukinuća Vojne krajine. To se područje počelo ubrzano razvijati za vrijeme polustoljetne Hrvatsko-ugarske nagodbe. Prva, a već i druga industrijska revolucija unosili su u to područje nova tehnička dostignuća. Počeli su se osnivati parni mlinovi nakon što su kupci drva iz Međimurja već posjekli najbolje drveće, pa gotovo da nema mašinista za parne strojeve, a nema još ni telefona ni električne struje. I pošte su rijetke, osobito u mjestima kroz koja ne prolazi željeznička pruga. Mnogo toga novog ipak nastaje, a staroga nestaje, jer uvoz industrijske robe iz Mađarske i Austrije malo-pomalo potiskuje proizvode iz kućne radinosti. Neke stvari obavljaju se isključivo u privatnim kućama, pa su i mesari malobrojni, a svinjokolje obavljaju spretniji seljaci; dvostrukost zanimanja vrlo je česta i svaki spretniji seljak, osim što je obrađivao svoju zemlju, radio je još i u šumi, u rudniku, u ciglani ili na prijevozu roba ako je imao konje.

Iz tablica možemo zaključiti koji su obrtnici bili najbrojniji. Svakako na prvo mjesto izbijaju krčmari, koji drže krčme, koje su ne samo mjesto gdje se mogla ispiti čaša vina ili piva već i mjesto dogovaranja i pregovaranja o trgovačkim poslovima, ali i vrlo živih rasprava o politici i sve intenzivnijem uključivanju ljudi određenog poreznog cenzusa u izborne borbe. Na to osobito djeluju škole, opetovnice, a poslije 1886. šegrti su obvezni na polaženje šegrtske škole kako bi dalje njegovali učenje i uspostavili međusobne kontakte, koji su se često održavali čitav život.

Osim krčmara, najbrojniji su oni obrtnici koji izrađuju i popravljaju poljoprivredne alate, tj. kolari, kovači i stolari. Poslije njih po brojnosti slijede mlinari i postolari, a krojači rade gotovo isključivo za muškarce. Žene svoje haljine izra- 
đuju gotovo isključivo same, a - izuzev u dva slučaja - nema ni modistica koje izrađuju šešire, premda su novine ipak reklamirale modu Beča ili Pariza; javljaju se i prvi pokušaji imitiranja te mode kod domaćih žena.

Modernizacija ipak pomalo dolazi i u ova tri kotara te se život mijenja suočen s političkim i gospodarskim krizama, rodnim i nerodnim godinama, oštrim zimama i velikim sušama, s bolestima i gladi te sve žešćom kritikom promađarske politike. Ona se u tim krajevima jako osjećala jer su Mađari sami ubirali poreze i poticali naseljavanje Židova i drugih stranaca, što je, na drugoj strani, opet dovodilo do odlaska naših ljudi u razvijenije dijelove Monarhije ili svijeta. Neki su se od njih vratili i obogatili naš život, dok su drugi bespovratno nestali $\mathrm{u}$ dalekom svijetu.

Cehova više nema, a i udruživanje obrtnika tek je na početku, jer se djelovanje zagrebačke Trgovačko-obrtničke komore osjeća samo preko Obrtnog zbora; tamo se polažu majstorski ispiti i evidentiraju obrtne radionice, ali su ti izvori rijetko sačuvani, čemu je razlog i tiho nestajanje obrtnika koji nisu uspjeli u svojem poslu.

Možemo zaključiti da je broj obrtnika na području današnje Koprivničko-križevačke županije bio relativno velik te da je stanovništvo na selu moglo zadovoljiti gotovo sve svoje potrebe od domaćih obrtnika, kupujući izvanredno na sajmovima i u gradu u trgovinama ono što nije moglo samo izraditi ili kupiti u svojim seoskim trgovinama. Otvorile su se velike mogućnosti obrtnicima i trgovcima to je razdoblje za njih bilo gotovo zlatno doba. Brojčani podaci u ovom radu daju odgovore na mnoga pitanja o tome tko se bavio kojim obrtničkim zanimanjem. Mnoga prezimena nalazimo i danas u Podravini, što ukazuje na izvjesnu vjernost obiteljskoj tradiciji i ljubavi za rodni kraj. Za stvaranje većih zaključaka trebalo bi istražiti posebice svaku struku i svakog obrtnika, dakle trebalo bi otvoriti projekt $\mathrm{u}$ kojem bi radilo više stručnih ljudi te izraditi komparativne podatke za čitavo područje djelovanja Trgovačko-obrtničke komore u Zagrebu. To bi bilo važno i zbog toga što je arhivska dokumentacija kotara Đurđevca i Virja uništena krajem 1943. godine, u vrijeme „partizanske republike“, pa osim sjećanja ljudi nemamo drugih vjerodostojnih podataka, a podaci iz vremena Vojne krajine do 1857. još su nedovoljno iskorišteni u znanstvenim istraživanjima.

Kod zaključaka moramo uzeti u obzir i različitost teritorija ondašnje županije od teritorija koji zauzima današnja županija, to jest da su Đelekovec i Legrad bili 1890. u Varaždinskoj županiji, a da Vrbovec i Gradec danas pripadaju Zagrebačkoj županiji.

Obrtnici rijetko postaju industrijalci. Akumulacija investicijskog kapitala kod njih je suviše mala, ali bi trebalo proučiti zašto su Židovi u tome bili uspješniji te zašto su preuzeli vodstvo u otvaranju tvornica u Hrvatskoj. Plemstvo po 
tom pitanju u sva tri kotara - osim u Križevcima, gdje djeluje Josip pl. Kiepach - nema gotovo nikakvu ulogu. Završen je već i proces raspadanja kućnih zadruga, pa ni one nemaju nikakvu ulogu u obrtu, osim onih koje su se reformirale $u$ proizvodne i prodajne. I crkvene organizacije rijetko drže neku krčmu ili mlin.

Unatoč kaotičnom stanju u obrtništvu, ono je bilo spremno za modernizaciju i industrijalizaciju. Mnogi obrtnici, odnosno članovi njihovih obitelji - sudeći po prezimenima - postali su u doba modernizma ugledni građani, koji su imali vodeću ulogu u svojim mjestima, ali je bilo i mnogo onih koji su napustili to područje ne ostavivši iza sebe nikakav trag. Neki su obrtnici propali te su prešli u kvalificirane radnike u tvornicama koje su se otvarale u prvoj polovici 20. stoljeća ili su pak otišli u veća mjesta s razvijenom industrijom kao što su Zagreb, Sisak, Varaždin i Karlovac, a neki i u inozemstvo. Ipak, mnogi su se zadržali na tom području, što možemo utvrditi po njihovim prezimenima. Ipak, nedostaju nam njihove obiteljske biografije kojima bi se utvrdio kontinuitet njihova života i rada na tom području.

Prema Adresaru koji objavljuje i imena i adrese trgovaca, kojih je 1890. na cijelom području današnje Koprivničko-križevačke županije bilo 314, odnosno u Koprivničkom kotaru 71 u gradu i 58 izvan, u Križevačkom kotaru 53 u gradu i 63 izvan te u Đurđevačkom kotaru u trgovištu 22, a 47 izvan, vidimo da su obrtnici bili gotovo tri i pol puta brojniji od trgovaca, odnosno da su upravo oni bili glavna noseća snaga izvanpoljoprivredne aktivnosti. Obrtnika je bilo u svakom, pa i najmanjem selu, pa su tu pustili svoje korijene; potomci nekih žive u tim selima i danas, dok su trgovci gravitirali prema gradu nastojeći da njihova djeca promijene društveni status. I danas proizvodi obrtnika nastali u vremenu sastavljanja Adresara čine glavni sadržaj brojnih gradskih muzeja i privatnih zbirki, pa nam je poznavanje imena tvoraca tih predmeta svakako vrijedno spomena. Koprivnička Podravina postala je poslije odlaska bana Khuen-Héderváryja najrazvijenije gospodarsko područje između Drave i Save.

Objavljivanjem dijela Adresara obrtnog i poslovnog svijeta g. 1891. želi se ukazati na činjenicu da je Hrvatska, usprkos intenzivnoj mađarizaciji, stajala na pragu novog stoljeća spremna za promjene koje je nosilo vrijeme primjenom tekovina druge industrijske revolucije. A na temelju ovog rada možemo prepoznati najupornije aktere tog procesa. 
Summary

\section{List of Artisans in the Territory of the Present Koprivnica-Križevci County in 1890}

The Koprivnica, Križevci and Đurđevac Districts were formed in 1886. Today, they represent the main parts of the present Koprivnica-Križevci County. This area first joined the process of demilitarisation of the Military Border in the form of the Križevci and Đurđevac Regiment, by connecting with the Banate of Croatia. This took place in 1873, when the railway connection Nagy Kanisza - Koprivnica - Zagreb - Rijeka became the principal traffic connection between Hungary and Rijeka as its only seaport and gateway to the world. Thanks to this fact, it became a perspective developmental area, extremely attractive to foreign artisans and tradespeople. Not only agriculture, but also handicrafts and trade were included; this influenced the change in the structure of employment and immigration of a large number of foreigners. Unfortunately, in the period between 1857 and 1890, i.e. at the time when the Monarchy had been restructured, no statistical lists had been drafted in the subject area. Therefore, the Address Book of Business and Trade in Croatia of 1891 - publication including the names of artisans and tradespeople, which was issued on Ban Khuen Héderváry's order on the occasion of marking the $40^{\text {th }}$ anniversary of the Zagreb Chamber of Trade in 1891 - represents a very important monograph. The Address Book indicates that despite the fact that neither urbanisation nor industrialisation had taken root by 1890, the number of artisans was high - in villages even more so than in district centres. The entire area was prepared for the process of modernisation and industrialisation, based on the exploitation of its own raw materials.

Keywords: handicrafts; Koprivnica District; Križevci District; Đurđevac District; 1890. 